\title{
Local Journalism under Private Equity Ownership*
}

\author{
Michael Ewens, Arpit Gupta, and Sabrina T. Howell ${ }^{\dagger}$
}

April 16, 2023

\begin{abstract}
Local daily newspapers historically played an important role in U.S. democracy by informing citizens about local policy issues. In a panel of 1,610 unique newspapers, we show that private equity acquisitions-which have increased over time and affect 262 newspapers in our data-lead to declines in local election participation. Other ownership changes do not. This is best explained by private equity shifting the composition of news away from local governance, accompanied by fewer reporters and editors. It is not explained by survivorship. Overall, the provision of news that is crucial for successful local democracy appears sensitive to firm ownership.
\end{abstract}

JEL: G23, G32, H42, L82

*We are grateful to Joshua Coven, Karin Hobelsberger, Ammon Lam, Jun Wong, and Shiyu Zhang for excellent research assistance. The authors would like to thank Victoria Ivashina, Arthur Korteweg, Song Ma, Theresa Kuchler, Jesse Shapiro, Andrei Shleifer, Johannes Stroebel, David Yermack, and seminar and conference participants at NYU Stern, the Southern California Private Equity Conference, the Western Finance Association, the FOM Conference, and the Utah Winter Finance Conference.

†Columbia Business School, NYU Stern, NYU Stern. Emails: michael.ewens@columbia.edu, arpit.guptalstern.nyu.edu, sabrina.howellenyu.edu. 


\section{Introduction}

Starting with De Tocqueville (1835), a large body of literature argues that local newspapers are crucial to modern representative democracy because they hold local leaders accountable and increase civic engagement (Snyder and Strömberg, 2010; Gentzkow et al., 2011). ${ }^{1}$ Over the past two decades, local newspapers in the U.S. have struggled to compete with social media and other new sources of content, leading to a vicious cycle of declining readership and revenue (Cagé, 2016). These internet sources are known to have lower local governance content (Falck et al., 2014; Gavazza et al., 2019). Meanwhile, voters' knowledge of local policy issues has declined, a trend that is associated with the increasing nationalization of U.S. politics, including the rise in straight-ticket voting based on partisan issues rather than location-specific policy positions (Hopkins, 2018; Moskowitz, 2018).

While much of the prior literature studies the role of shifting consumer preferences in driving these trends, we focus on an important supply-side change: the entry of private equity investors into the local newspaper industry. The share of newspapers owned by private equity funds has increased from about 5\% in 2002 to about $23 \%$ in 2019 (Figure 1). Across the world, newspapers have typically been owned by the state or families; Djankov et al. (2003) document this pattern and present the private benefits of control, including fame and influence, as rationales for concentrated private sector media ownership. Private equity ownership represents the opposite end of a fundamentally different model, in which the main agenda is to quickly increase firm value and maximize profits as opposed to non-pecuniary amenities.

Perceived cost-cutting following newspaper buyouts has received widespread criticism in the news media. In this view, the single-minded pursuit of shareholder returns-which is more high-powered under private equity than other types of ownership_leads to an evisceration of local news, resulting in a loss of local monitoring functions provided by newspapers and a decline in government accountability (Kuttner and Zenger, 2017; Lewis, 2018; Shephard, 2018; Smith and Chiglinsky, 2020). ${ }^{2}$ An alternative perspective is that private equity ownership leads to investments in digital platforms and efficiency gains

\footnotetext{
${ }^{1}$ Section 1.1 contains an extensive review of this literature. De Tocqueville (1835) wrote that the United States "makes use of an unlimited freedom of political association ... Newspapers make associations, and associations make newspapers... Thus, of all countries on earth, it is in America that one finds both the most associations and the most newspapers."

${ }^{2}$ For example, after private equity-owned GateHouse purchased a newspaper, an editor was quoted as saying: "I'm sweating bullets hoping some bean counter doesn't say we've got to get another $17 \%$ profit out of this. How much more can these people cut? It becomes harder to do the right thing-to cover the city council meetings and find out what really did happen-when you had five people in the newsroom and now you're down to two" (Kuttner and Zenger, 2017).
} 
that enable newspapers to survive and even thrive in a new environment. For example, a press release from the newspaper publishing unit of private equity firm Versa Capital Management explains that " $[t] h e$ company achieved significant cost synergies by successfully streamlining operations. It also launched new on-line and mobile platforms and introduced a number of creative revenue initiatives." 3 In this view, investment in information technology need not compromise the quality of local news reporting.

This paper studies the impact of private equity ownership on political participation, alongside newspaper operational outcomes. We digitize 17 years of Editor \& Publisher International Yearbooks of daily newspapers from 2001-2017 and combine them with digital versions through 2019. The data contain basic information on a comprehensive sample of daily newspapers in the U.S. We connect these data to annual information on ownership, employment, and article content. To our knowledge, this is the first data set of newspapers from recent years in the U.S. and is the only one to include several interesting variables such as employment. We hope it will be useful for future research. ${ }^{4}$

Our digitized panel data includes 1,610 unique newspapers, 262 of which have ever been owned by private equity. These newspapers were either purchased in one of 56 deals or were subsequently acquired by a private equity-owned chain. We find that private equity tends to target newspapers inside of larger groups, that charge higher advertising rates, are members of chains, and that have relatively higher circulation.

To explore the association between transitions to private equity ownership and local political participation, we study local elections before and after changes in private equity ownership for papers in the area. We use a difference-in-differences model with fixed effects for newspaper and year, which allows us to estimate the impact of a newspaper's transition to private equity ownership, relative to other newspapers in the same year. Our analysis begins with a focus on county commissions and councils, institutions responsible for overseeing county governments that handle local taxation, infrastructure, and judiciaries. After a private equity buyout, we show that total votes and voter turnout decline in county-level elections. Specifically, voter turnout decreases by 0.82 percentage points, relative to a mean of $9 \%$. There are similar declines in mayoral and sheriff elections, although the data are more limited, resulting in weaker statistical significance. Next, we document similar results at higher levels of

\footnotetext{
${ }^{3}$ https: / / www.businesswire.com/news/home/20141009006229/en/Civitas-Media-CEOAnnounces-Stepping.

${ }^{4}$ The authors will post the daily newspaper ownership data for public use.
} 
government. Using data on U.S. State legislative elections at the district-year level, we find that a higher share of private equity-owned papers is associated with significantly fewer votes and elections that are less competitive. Last, at the Congressional level, private equity ownership of a newspaper in a district is associated with fewer votes, lower turnout, and a higher chance of re-electing the incumbent. Regarding the sitting member of Congress, we see declines in the number of bills proposed, a measure of policy-making productivity.

We also consider citizen engagement using survey data. We find that private equity buyouts increase the fraction of people who have no opinion about their U.S. House Representative by two percentage points (relative to a mean of 18\%), while having no effect on opinions about the U.S. President. Overall, these results suggest lower participation in local democracy after private equity buyouts, which raises concerns about deteriorating local government accountability.

One channel for these relationships could be less information production about local government. Historically, local governance content in newspapers has been shown to affect voter turnout, voter decisions, and ultimately government policy (see see Section 1.1, especially Gentzkow (2006); Snyder and Strömberg (2010); Gentzkow et al. (2011); Hayes and Lawless (2018)). Local newspaper reporting often spills over beyond the paper's readership, because local television and especially social media rely on it as a source of information about local government issues..$^{5}$ Internet sources, including social media, do not appear to offer a meaningful substitute for newspapers' traditional local issue coverage. Instead, the emerging literature on the role of the internet and social media in politics suggests that these outlets rely on newspapers for source material while also contributing to the nationalization and segregation of news consumption (again, see Section 1.1). Therefore, changes to newspaper content can affect public knowledge far beyond the newspaper's readership.

To explore this channel of changing information provision, we consider local policy reporting. If producing content about local government is relatively more expensive-for example, requiring more journalists and local office space—and private equity firms seek to quickly improve profitability, then we expect a newly private equity-owned newspaper to shift away from local content production. Consistent

\footnotetext{
${ }^{5}$ Such information spillovers have implications for revenue; for example Ardia et al. (2020) note that " $\left.\mathrm{t}\right]$ he platforms are able to mediate the relationship between news consumer and news producer, forcing news outlets to use platform-based services to reach their audience and collecting the profits from advertisers. Consumers increasingly rely on social media as their source for news, enhancing revenue for platforms at the expense of news providers who are losing advertising income while they still bear the cost of reporting the news." Also see Shearer and Mitchell (2021) and Martin (2018).
} 
with this prediction, the share of articles in a newspaper concerning local governance, which includes words such as "city council," "zoning," and "state legislature", declines following private equity buyouts by 3.6 percentage points, which is $10.8 \%$ of the mean.

Instead of local news, private equity firms may produce more national news content, which can be syndicated across many different papers. Indeed, we observe an increase in the share of articles on national politics (which includes words such as "Obama," "Bush," and "White House") of 1.3 percentage points $(8.3 \%$ of the mean). These results indicate a change in focus towards national news-which is more centrally produced and cross-syndicated to many newspapers within the same ownership structure-and away from local news. They do not reflect more overall articles; to the contrary, we find that the total number of articles declines by $16.7 \%$. Thus, while the industry overall has been in a period of structural change, there appears to be a particular impact of private equity buyouts on the composition of news.

One concern is that declining civic engagement and local government news following private equity acquisitions could reflect changing local preferences if private equity owners are more sensitive to demand. To test this hypothesis, we employ data from Google Trends on local internet searches for the same keywords that define the local government and national politics content in our analysis above. We find that searches for local government content increase after buyouts, while there is no impact for national politics content. This suggests that interest is not declining and points to the possibility that consumers are trying — apparently unsuccessfully—to find the same information online.

Cost savings represent the most obvious rationale for the decline in local government content. There is a fixed cost to producing new reporting. In contrast, once a non-local article exists it can be disseminated through additional newspapers at a very low marginal cost. Under this hypothesis, we expect to observe a decline in employees at local newspapers, particularly reporters. Indeed, we find that the number of reporters decline by $7.3 \%$, and the number of editors decline by $8.9 \%$. By contrast, the number of interns and freelancers-who represent lower paid, casual labor-remains unchanged.

We consider several additional operational outcomes. First, private equity buyouts are associated with print circulation declines. We find increases in digital circulation, though this should be interpreted with caution as we are only able to observe digital circulation for a small portion of the sample. However, it offers suggestive evidence that private equity-owned newspapers invest in information technology, as in 
Agrawal and Tambe (2016). Third, we find significant decreases in newspaper closure rates, suggesting that, at least within the span of our data, private equity owners do not quickly shut down firms after extracting rents. Consistent with the targeting analysis discussed above, this indicates that our results do not simply reflect private equity owners selecting declining newspapers. Importantly, the main resultson politics, article content and employment-do not reflect survivorship or digital technology, as they persist both among survivor newspapers and among survivors with digital circulation.

The changes that emerge after private equity buyouts raise the question of whether other organizational forms have similar effects. We comprehensively classify each newspaper-year as having one of seven ownership types. All other ownership types correlate with more local governance content. Family-owned and, to a lesser degree, independent newspapers are causally associated with more local governance content. These ownership types, as well as private chains that are not family-owned, also retain more employees. Finally, we show that the impacts of private equity are independent of consolidation effects, which Fan (2013) finds to be relevant in the newspaper market. Together, these results give us some confidence that there are particular impacts of private equity ownership. However, given the sparsity of data for some outcomes-and hence statistical noise-further research is needed, and we hope that our paper and the data it employs can serve as building blocks for future studies.

This paper's main contribution is to shed light on the implications of newspaper ownership for political participation. We focus on private equity, which is playing a growing role as a type of newspaper owner and has particularly high-powered incentives to create short-term value. These incentives to maximize profits may be poorly aligned with the public good characteristics and implicit contracts involved in reporting about local government. Consistent with this, we see declines in local government news content and reporter employment following transitions to private equity ownership. In turn, civic engagement declines, which appears to reflect newspaper readers and outlets that rely on newspaper reporting having less information about local government. Note that the role of newspapers in fostering informed civic engagement is unique, so we do not expect our results to be especially relevant to private equity's effects on operations in other industries. 


\subsection{Motivating Context and Literature}

In this section, we discuss three research areas that we build on and which provide important assumptions for our analysis: (1) How media exposure relates to political outcomes; (2) Whether social media substitutes for traditional news; and (3) The effects of private equity on consumers and other stakeholders.

Media and Politics. The first strand of literature documents that local governance content in newspapers affects voter turnout, voter decisions, and ultimately government policy. Perhaps most relevant, Gentzkow (2006) shows that the decline in voter turnout in the second half of the $20^{\text {th }}$ century is linked to the substitution of newspapers and radio by television, which conveyed less political knowledge. Gentzkow et al. (2011) show that when a newspaper initially enters a market there is a large positive effect on political participation; while this effect declines over time for Presidential turnout, it persists for Congressional elections until the end of their sample in 2004. Also in this vein, Snyder and Strömberg (2010) show that when local newspapers reduce coverage of a U.S. House representative, the Congressman is less likely to work for the constituency in Congress, is less likely to vote against the party line, and his district receives less federal spending.

From the political science literature, Hayes and Lawless (2015) and Hayes and Lawless (2018) find that media coverage of local issues and elections is associated with civic engagement and competition in U.S. House of Representatives elections. Filla and Johnson (2010) find that people with access to a daily local newspaper are more likely to vote regularly. When areas lose a local newspaper, Darr et al. (2018) and Rubado and Jennings (2020) find that voters are more polarized and elections are less competitive, respectively. Further evidence that newspaper and radio content affect policy includes Strömberg (2004), Dyck et al. (2008), Ferraz and Finan (2008), Drago et al. (2014), and Barthel et al. (2016).

Gao et al. (2020) find that local newspaper closures negatively affect long-run municipal borrowing costs because there is less information available about the quality of local government. In addition to studying different and broader outcomes, we focus on the changing composition of local news among operational newspapers rather than on the extensive margin of newspaper failure. This distinction is important because over $80 \%$ of newspapers survive over our sample period, despite the stresses in the industry (Table 1), while large fractions of surviving newspapers experience private equity ownership 
(21\%, see Figure 1).

There is also evidence that the media affects partisanship. For example, DellaVigna and Kaplan (2007) show that Fox News' entry in U.S. localities increased the Republican presidential vote share. Gerber et al. (2009) show that exposure to more newspaper media in Virginia increased voting for Democrats, even when the newspaper slant was Republican. ${ }^{6}$ Our finding that there is less local and more national content in newspapers after private equity buyouts is related to the overall trend of nationalization in U.S. politics; in recent decades, state and local election outcomes are increasingly correlated to national election outcomes because fewer people vote for different parties in local (e.g., House) elections than in Presidential elections (Jacobson, 2015; Abramowitz and Webster, 2016; Hopkins, 2018). Martin and McCrain (2019) argue that this is related to conglomerate ownership of local television stations, which has been associated with a strong rightward shift in coverage. Moskowitz (2018) connects these trends to local news coverage. He shows that when voters have less exposure to news about local candidates' policies and performance, they are more likely to submit a "straight-ticket" ballot, in which national and more partisan issues are applied to local elections, even though the policies at stake—such as local infrastructure projects or school programs-have little to do with the national, partisan issues.

Our research also connects with work on media markets. For example, Angelucci et al. (2020) study the entry of national television news in $20^{\text {th }}$ century America and find that there was a negative shock for local newspapers, leading to a decline in original reporting and, crucially, local news. Related to our hypothesis that owner profit motives affect news content, Gurun and Butler (2012) show that newspapers cover local firms (who provide advertising revenue) more positively than other firms. Fan (2013) estimates the effect of newspaper mergers with data from 1997-2005. Our research question concerns the type of newspaper ownership, and our results do not reflect within-media market mergers. Other work on media competition includes Groseclose and Milyo (2005), Gentzkow et al. (2014), Puglisi and Snyder (2015), Gentzkow and Shapiro (2010), and Cagé (2020). Finally, there has been analysis of the rise of billionaire control of newspaper outlets (Durante et al., 2019; Grossman et al., 2020).

\footnotetext{
${ }^{6}$ There is also evidence from outside the U.S. Using the staggered introduction in Italy of Berlusconi's private TV network, Durante et al. (2019) show that exposure to Berlusconi's network increased viewers propensity to vote for his party, in part because the content made viewers less civic minded. Enikolopov et al. (2011) demonstrate that an independent anti-Putin broadcaster in Russia reduced voting for the Putin government party substantially. DellaVigna et al. (2014) provide evidence that exposure to nationalistic content in a rival ethnic group's media increased ethnic hatred in the Balkans.
} 
In sum, this body of work provides strong evidence that newspapers have been essential-especially in the U.S.- for maintaining citizen engagement and policymaker accountability. This supports the connection that we draw between declining local governance content in newspapers and reduced voter turnout in local elections.

Social Media. A growing literature indicates that internet sources of news, especially social media, do not offer meaningful substitutes for the traditional local issue coverage found in newspapers. For example, Levy (2020) shows that Facebook algorithms limit exposure to counter-attitudinal news, and thereby increase polarization. There is also evidence that social media increases the prevalence of fake news about politics (Vosoughi et al., 2018). In particular, Allcott and Gentzkow (2017) show that Facebook is four times more likely to be visited immediately before a visit to a fake news website than before a visit to a real news website.

Similar to the findings of Gentzkow (2006), Falck et al. (2014) document that internet availability has negative effects on voter turnout, which they attributed to reduced information via television. Gavazza et al. (2019) also demonstrated that in the U.K., more time spent on the internet decreased voter turnout by crowding out consumption of media with more news content, especially newspapers. While there is evidence that people who deactivate their Facebook accounts have less knowledge about national politics (Allcott et al., 2020), and research on non-democratic countries finds that social media penetration increases political protests (Qin et al., 2019; Enikolopov et al., 2020), in Western countries research indicates that under certain circumstances, access to broadband internet or social media increase nationalism, hate crimes, and political polarization (Bakshy et al., 2015; Sunstein, 2018; Schaub and Morisi, 2019; Bursztyn et al., 2019; Müller and Schwarz, 2019). For example, Lelkes et al. (2017) show that in the U.S. in the 2000s, access to broadband internet increased partisan hostility.

We conclude based on this literature that internet- or social media-based news does not thus far offer objective information about sub-national policy issues in democratic countries and therefore is unlikely to provide an unbiased, full substitute for a decline in local government content at local newspapers. Conversely, growing evidence suggests that these sources increase nationalization of news content and polarization. This leads us to argue in our analysis that less local government content in local newspapers implies less information available to citizens.

Private Equity. This paper also contributes to a growing literature studying how private equity 
affects product quality, labor, and other stakeholder outcomes in various industries. It is well-known that private equity ownership is associated with exceptionally high-powered incentives to maximize firm value (Kaplan and Stromberg, 2009; Boucly et al., 2011). These incentives do not necessarily imply operational changes if, for example, managers rely on leverage and tax strategies to generate returns (Axelson et al., 2013). Alternatively, managers may be particularly good at screening, and choose targets that are on trajectories toward better outcomes (Guo et al., 2011; Acharya et al., 2013).

However, there is abundant evidence that private equity managers actively intervene in company management, consistent with our findings. Existing work has found largely positive implications for product quality, employees, and consumers (Davis et al., 2014; Agrawal and Tambe, 2016; Bernstein and Sheen, 2016; Davis et al., 2019; Fracassi et al., 2020; Cohn et al., 2017; Gao et al., 2021; Gornall et al., 2021; Howell et al., 2022). In one of the only other studies of a distressed industry, Johnston-Ross et al. (2021) document positive effects of private equity buyouts of banks after the Great Financial Crisis. In the context of education and healthcare, which are characterized by both public goods provisions as well as intensive government subsidy, Eaton, Howell and Yannelis (2019) and Gupta et al. (2020) found negative effects on student and patient outcomes, respectively, after private equity buyouts. In an analysis of newspaper content, Turkel et al. (2021) finds that financial investors have little impact on investigative journalism. Our analysis is much larger and more systematic.

Finally, there is a literature related to high-powered incentive compensation, which is important for the key mechanism underlying our focus on ownership type: high-powered incentives impact product outcomes. A traditional view of convex compensation schemes-corresponding to the option-like profits for private equity fund managers-is that they should lead to greater risk-taking (Grinblatt and Titman, 1989; Jensen and Meckling, 1976; Palomino and Prat, 2003). In our context, we might observe more highly successful newspaper chains under private equity ownership, but also more failures and shutdowns. In contrast, we observed that the probability of closure declines. Carpenter (2000) presents a theory consistent with these results, showing that when a manager is paid with an option he cannot hedge, the option compensation does not lead to more risk seeking, especially when the evaluation date is far away. This is in part because leverage magnifies the manager's exposure to the asset volatility. ${ }^{7}$

\footnotetext{
${ }^{7}$ Also see Goetzmann et al. (2003) and Kouwenberg and Ziemba (2007).
} 


\section{Data Sources \& Descriptive Statistics}

In this section, we describe the sources of data that we use, and explain how we construct a dataset for analysis. First, we develop a panel of U.S. local daily newspapers (Section 2.1) supplemented with newspaper audit data from the Alliance for Audited Media. Second, we collect newspaper ownership data (Section 2.2). Third, we collect outcome data on local political elections (Section 2.3), newspaper article content (Section 2.4), and newspaper employment (Section 2.5).

\subsection{Daily Newspaper Data}

We digitize 17 years of Editor \& Publisher (E\&P) International Yearbooks of daily newspapers from 2001-2017, which contain basic information on essentially every daily newspaper in the U.S. ${ }^{8}$ E\&P data are traditionally used primarily by advertisers, and for this reason have audited circulation coverage. By circulation we generally refer to print circulation unless we specify digital circulation instead. We combine these digitized records with a digital version of the data in 2018 and 2019 provided by E\&P. The resulting dataset includes 1,610 unique newspapers.

An example of the structure of these books is in Appendix Figure A.1. The variables we obtained from E\&P are newspaper name, parent (or "group") name, circulation, and advertising rates. Circulation refers only to print subscriptions. We supplemented the E\&P circulation data with information provided by the Alliance of Audited Media. Their database tracks both print and digital media subscriptions, while also providing geographic coverage of the former. Advertising rates are calculated as the dollars charged per open inch, which is the price that a new advertiser, who does not have existing discounts, would be charged for one square inch. ${ }^{9}$ During the computer reading of the images, some text proved to be unreadable, and despite a great deal of manual cleaning, there are missing newspaper-years for some variables. This is one reason for different sample sizes across variables from E\&P.

The group names in E\&P do not always reveal ultimate newspaper ownership structure and in turn, ownership type. In some cases, a local newspaper is assigned to a group that is itself owned by a parent

\footnotetext{
${ }^{8} \mathrm{E} \& \mathrm{P}$ also tracks weekly newspapers, but we focus on dailies as they are more likely providing consistent, up-to-date local news coverage. For this reason, we also drop USA Today and the Wall Street Journal from our sample.

${ }^{9}$ We do not use data on subscription price for two reasons. First, it is not recorded consistently in the E\&P data, for example with some newspapers having only monthly data and others daily. Second, there is widespread tiered pricing and discounts, with some newspapers having many price levels depending on the nature of the subscription. Therefore, it is impossible to obtain a consistent price measure even if we observed all the price levels, because we do not observe the distribution of prices across subscribers.
} 
group. To address this issue, we supplement the list of group-year data with an index of newspaper groups from the appendix of some of the E\&P yearbooks, which contain indices listing parent group, subsidiaries, and newspapers. These data provide information on full ownership structure and help to fill in the gaps from the machine-reading of the PDFs. Next, E\&P also has lags in its tracking of ownership changes. For all instances of group name changes, we hand-checked the ownership change and searched for exact dates of such changes. This step is crucial for the non-private equity ownership changes because there is no commercial data provider, like PitchBook, tracking buyouts or mergers of newspaper companies.

\subsection{Ownership Data}

Private Equity Ownership. Our primary source of data on private equity transactions is a proprietary list of deals compiled by PitchBook Inc., a leading market intelligence firm. To create the list, we search PitchBook for all U.S.-based newspaper or media acquisitions through 2019 that involved a private equity sponsor. We merge the targets of these deals, which are typically parent companies, to the E\&P newspaper data using the group or ultimate parent name, and in some cases merged by hand. In sum, we identify 56 deals in which 168 unique newspapers were acquired. The now private equity-owned chains subsequently acquired an additional 94 newspapers. Therefore, we observe a total of 262 newspapers under private equity ownership at some point during our sampling period from 2001-2019. ${ }^{10}$

Measured by number of newspapers acquired, the most active private equity firms in our sample are Leonard Green Partners, Blackstone, Fortress Investment Group, Versa Capital Management and Providence Equity Partners. All are traditional private equity firms except for Fortress, which has a range of strategies including private equity. Among them, only Providence has a significant focus on media, while the remaining invest in a range of industries and geographies. For example, around the time that Versa Capital created Civitas Media to purchase U.S. newspapers, it purchased a restaurant chain, storage company and wireless provider. In nearly all the deals we observe, the private equity firm obtains majority or full ownership of the newspaper or newspaper chain via a holding company. These layered ownership structures complicate our efforts to assign newspapers to private equity ownership, and almost certainly lead us to underestimate the number (and share) of newspapers that are private

\footnotetext{
${ }^{10}$ The 2019 data on private equity deals is only used for the first two figures in the paper. Other information for that year is a work-in-progress.
} 
equity-owned.

Other Ownership Types. We supplement the PitchBook data with manual identification of owner type for each newspaper-year in our data. This process involved hand-checking the ownership type and historical ownership changes of each newspaper. We assign newspapers to one of the following mutually exclusive categories: family, independent, non-profit, hedge fund, other financial firm, partnership, pension fund, private chain, private equity, and public company. The family status takes precedence over other ownership types; that is, if a chain is family-owned, we call it family-owned and not part of a private chain. Independent newspapers have standalone (i.e., non-chain) ownership and are not family-owned.

We do not treat hedge funds as private equity as they have a different incentive structure, including long-term holding periods. We also do not consider them on their own as there is only one hedge fund in the data: Alden Capital, primarily through its ownership of MediaNews Group. Further, hedge funds differ from private equity in the open-ended nature of their investment horizon period, which does not result in the same incentives for short-term profit seeking. Prior literature on the impact of hedge fund interventions on corporate value emphasize resulting operational improvements in labor productivity and innovation, including Brav et al. (2015). We observe similar results when combining private equity and hedge fund owned newspapers.

Ownership Trends Over Time. These data allow us to document the rise of private equity ownership in the newspaper industry. In Figure 1 we show the share of newspapers and the total number of newspapers owned by private equity firms each year. While there is both entry and exit, on average private equity ownership increased from just under 5\% in 2002 to $21 \%$ in 2019 . We place this increase into the broader industry context in Figure 2 Panel A. This figure documents industry ownership dynamics by charting the number of newspapers owned under each of the major categories in each year. As there are very few partnerships and non-profits, we grouped these together with the unknown ownership category. We combined pension funds, the single hedge fund, and other financial firms into a single category called "Other Financial Firms." A clear trend is the marked decline in the share of newspapers that are part of private chains. Inspecting the data, we find that many of the transitions to private equity, hedge fund, or public company ownership are from private chain status. 
The figure yields two other noteworthy insights. First, while the total number of newspapers was roughly constant around 1,500 until 2012, subsequently we see a steady decline. Second, the share of family-owned and independent newspapers has been, perhaps surprisingly, constant over time with the latter even increasing slightly. The increase in independent newspapers seems to stem from cases in which a chain of two to three newspapers breaks apart, either because one of the newspapers are purchased by a larger company, for example a publicly listed entity such as the McClatchy Company, or because one closes, leaving a single standalone newspaper.

\subsection{Political Data}

To study changes in political participation at local levels, we use four types of election data.

County Elections. The first is county-level election data, which we acquire from the Local Elections in America Project (LEAP) at Rice University. This has been used in the political science literature, for example in de Benedictis-Kessner and Warshaw (2020). We consider vote totals in three types of local elections. First and most important are county legislative elections, which elect county commissions and councils. These entities oversee local government, local taxes, and other local administrative services including infrastructure and judicial functions. Elections to these offices, as a result, are likely to be very local races for which we expect local news commentary to be most important. From the same LEAP data, we also obtain data on mayoral and sheriff elections. While these are sparser and do not always map to a newspaper area, they are important for city governments. We convert voting totals to turnout percentages using county-year population data from the U.S. Census Bureau. The election data exist only for a subset of newspaper years, both because elections do not happen every year and because not every county has election data reported in the LEAP files.

State Legislative Elections. Next, we collect information on U.S. State legislative elections at the district-year level from Klarner (2018). ${ }^{11}$ A state legislative district is different (and much smaller than) a Congressional district. These data—containing information on 105,001 district-level elections—-have been assembled to enable study of politics at lower levels of government. They have been broadly used across political science for this purpose (e.g., Berry et al. (2010)); one such user of the data comments

\footnotetext{
${ }^{11}$ The data are available here: https://dataverse.harvard.edu/dataset. $x$ html ?persistent Id=doi: $10.7910 /$ DVN/DRSACA.
} 
they are the "largest collection of election data ever analyzed at once" (Katz et al., 2020).

These data include the number of votes, the number of candidates up for election per available seat, and the number of votes for the winner and runner-up, among other variables. Unfortunately, turnout is not observable because there is no information about registered voters at this geographic level. We merge these data to the newspaper-year panel by constructing a district-year panel in which the key independent variable is an indicator for the district having a local paper that is private equity-owned. We define the newspaper as serving the district if the district is in the paper's Designated Market Area (DMA). ${ }^{12}$ These data allow us to observe the number of votes in the election (by candidate), the number of candidates running, whether an incumbent ran in the election (and won), and a host of characteristics about the candidates' political experience.

Congressional Elections. We gather information about general Congressional elections from two sources. The first is the CongressData database created by the Institute for Public Policy and Social Research at Michigan State University. ${ }^{13}$ In these data, we can study election outcomes and the activity of the district's sitting member of Congress, such as his proposed number of bills and which committees he sits on. The second is the MIT Election Data and Science Lab's U.S. House Election database. ${ }^{14}$ These data contain information about voting activity, including the number of votes and share of votes for each party. We construct turnout by combining these data with information about the voter eligible population from the American Community Survey at the U.S. Census Bureau. ${ }^{15}$ These election variables are at the Congressional district level and are available only for Congressional election years. We therefore construct a dataset at the Congressional district-Congress level, also using a DMA-based match.

Survey Data. As an alternative to real political outcomes, we gather survey responses from the Cooperative Congressional Election Study (CCES) across the 2006-2019 waves. CCES is a national survey administered by YouGov, with over 50,000 individuals surveyed annually, using a stratified

\footnotetext{
${ }^{12}$ Using DMAs is a standard way to define media markets geographically in the U.S. Although they were created for television and radio, they can be applied to newspapers as well. For more information and a list, see https: //outdoormediabuyers.com/list-of-u-s-dmas/. We require a meaningful (>.2) fraction of newspapers to be private equity owned in order for the indicator to take a value of 1 , since DMAs are larger than legislative districts.

${ }^{13}$ The data are available here: https: / / cspp.ippsr.msu.edu/congress/.

${ }^{14}$ The data are available here: https://dataverse.harvard.edu/dataset.xhtml?persistentId=doi: $10.7910 /$ DVN/IG0UN2 \& version=10 . 0 .

${ }^{15}$ The data are available here: https : / / www . census. gov/mycd/ ? st $=35 \& \mathrm{~cd}=02$.
} 
sample procedure. We focus on variables related to news interest and whether an individual has any opinion about their elected representatives. For these variables, we develop a treatment measure of whether there are any private equity-owned papers in the county-year.

\subsection{Article Content Data}

We obtain data on textual frequency of local news content using the NewsLibrary dataset, as in Gentzkow and Shapiro (2010). We can identify 745 of our 1,610 unique newspapers in the NewsLibrary data, which represents $44.5 \%$ of total U.S. circulation as of 2018. To identify content, we first manually code a random subset of articles, and then search for words identified with certain types of content across the whole dataset. We use automated scripts to assess the frequency of words associated with these categories of news. ${ }^{16}$

We are most interested in articles in a newspaper that contain local policy and governance content. As explained in Section 1.1, this type of coverage is strongly associated with higher civic engagement and a more robust democracy. We construct a set of articles that contain local government content. Importantly, we are interested in words that reflect news relevant to a citizen's information set about local governance and elections. The goal is not to capture whatever the newspaper management might think is "local." For example, a story about a lost cat might be local, but is clearly not relevant for civic engagement with local government.

Therefore, to construct our keywords, research assistants manually classified a test series of articles from non-PE owned newspapers as concerning local government or not. We then extracted a parsimonious list of the most common words concerning local government in those articles that contained substantive references to different aspects of government. While this process was researcher-led, it was objective and was conducted in a way that is orthogonal to any possible private equity treatment effects. It is in the same spirit as the narrative approach that Romer and Romer (1989) and Romer and Romer (2010) take to manually classify monetary shocks and the reasons for tax changes, respectively. In Section 7, we present a machine-learning based approach to identifying local content as an alternative.

This process yielded the following words: city council, city hall, mayor, state senate, state legislature,

\footnotetext{
${ }^{16}$ We restrict analysis of all news content variables to newspapers that have at least 300 articles.
} 
zoning, and planning board. Articles containing one or more of these words are classified as concerning local government. We also consider obituaries, which in local newspapers predominantly concern the deaths of local citizens and thus tend to require more local employee time. We identify obituaries as articles including any of the following words: died, finally at peace, or passed away. Although we believe that the keywords we use are, as a group, inherently important, of course there may be other effects on content that we do not measure.

Beyond local government, we are also interested in evidence of non-local content that could be syndicated across multiple newspapers, potentially achieving cost savings. The obvious choice here is national politics content, which we define as including any of the following words: Bush, Congress, Obama, Trump, White House, Democrat, Republican. Newspaper groups could create this cross-newspaper content in-house, or they could purchase content from the wire syndication companies. To assess this latter possibility, we identify articles from the Associated Press wire service. While there are other wire services, the Associated Press is the most easily observable in the content data and not conflated with other topics that might have the same name as the wire service. We further constructed two supplementary categories. One is about local schools, which includes the words: board of education, school board or school district. Second, as a proxy for international news coverage, we locate articles including either of the words China or Russia. For all of these categories, we consider the share of a newspaper's articles with a certain type of content as well as the total number of articles by content type.

\subsection{LinkedIn Data}

To augment our sample with employment information, we use LinkedIn data. ${ }^{17}$ The data include information on over 300 million individuals with public LinkedIn profiles as of May 2017. Crucially for our purposes, LinkedIn profiles contain detailed work histories, and so capture extended data prior to the study period for individuals with public profiles. We can identify 766 of our 1,610 unique newspapers in the LinkedIn data with at least one reporter.

We extract job titles from the LinkedIn data for all individuals identifying themselves as employed at the newspaper as of a given year. This allows us to identify the number of people with certain job titles

\footnotetext{
${ }^{17}$ These data were originally scraped by a commercial analytics firm. Legal precedent in hiQ Labs v. LinkedIn protects the rights of academics and other third-parties to use scraped data from publicly available LinkedIn profiles.
} 
on a panel basis for each newspaper. We create a "Reporters" variable which includes all people with the word reporter or journalist in their job title. We also identify "Editors" as people with the word Editor in their job title, and "Interns and Freelancers" as people with either of those words in their job titles. Finally, we consider all employees as well. ${ }^{18}$

\subsection{Summary Statistics}

Statistics on the outcome variables employed in this analysis are shown in Table 1. The top two sets concern the share and number of articles in a given newspaper-year that cover particular content areas, as defined in Section 2.4. The next set contains data on employment from LinkedIn. The following two sets report variables from E\&P, with the maximum number of newspaper-years in the data on closure. Specifically, we observe print circulation and advertising rates, both of which have large standard deviations. As can be seen in the examples in Appendix Figure A.1, some newspapers charge only a few dollars per open inch, while others charge hundreds of dollars. Finally, the last sets contain election data, which exists only for a subset of newspaper-years as explained above. These variables are summarized in levels, but we usually consider log transformations in analysis. ${ }^{19}$ The table indicates that private equity-owned newspapers are on average smaller than other types of newspapers, with about $60 \%$ of the total number of articles, $69 \%$ of the employees, and $82 \%$ of the circulation.

Panel B of Figure 2 provides basic information about the major ownership types with three means calculated across all newspaper-years: the share of total newspaper-years, the share of content that concerns local policy, and the number of reporters per ten articles (excluding individuals who identify themselves as interns). Private equity is characterized, on average, by the lowest share of articles on local policy, at $32 \%$. The highest share is for other financial-owned newspapers (e.g., by pension funds), at $46 \%$. Interestingly, the number of reporters per ten articles published, which is related to the degree of syndication, centralization, and investigative effort, is highest among newspapers owned by private chains, at nearly $30 \%$. Private equity-owned newspapers have far fewer reporters per ten articles, at just

\footnotetext{
${ }^{18}$ Because our analysis uses self-reported job and occupational classifications, it is possible that underlying job functions may change while formal job titles remain the same. Our baseline results, focusing on the number of total employees, are less sensitive to this possible concern.

${ }^{19}$ Note that the data samples differ for the first three sets of variables, as only a subset of newspapers match to each external source, as explained previously. With E\&P, we could not parse circulation and advertising for all newspaper-years. All variables that are unbounded above (including the total number of articles, employee counts, circulation, and total votes) are winsorized at $2.5 \%$ level on both sides, which is a restriction we make throughout the paper.
} 
$2 \%$. The next-lowest is publicly listed companies. Of course, there are many possible structural reasons for these differences. Notably, private equity ownership tends to occur later in the study period, after newspaper revenue and attention share had in general declined substantially. This change highlights the need for a within-newspaper comparison that also controls for time trends.

\section{Empirical Strategy}

For each outcome, we present two difference-in-differences regression estimates: one that compares the post-buyout period to the pre-buyout period, and one that estimates the dynamic impact for each year around the buyout. Both approaches include newspaper and year as fixed effects. In other words, we compare newspapers after versus before private equity ownership to other newspapers that never come under private equity ownership, while allowing for an average effect on the whole industry of being in each year. The first regression model is:

$$
y_{i t}=\alpha_{i}+\alpha_{t}+\beta P E_{i t}+\varepsilon_{i t}
$$

Here, $y_{i t}$ represents an outcome such as voter turnout or the log number of reporters. $\alpha_{i}$ and $\alpha_{t}$ are two vectors of fixed effects controlling for the average of the particular newspaper and year respectively. The coefficient of interest $\beta$ represents the relative differences of private equity ownership. We cluster standard errors by newspaper.

The dynamic difference-in-differences specification in Equation 2 follows a standard event-study design as in Autor (2003) and Almond et al. (2011). This second approach separately estimates coefficients for each year around the buyout using the following equation:

$$
y_{i t}=\sum_{s=-19}^{t=19} \beta_{t} \mathbf{1}\{t=s\}+\alpha_{i}+\alpha_{t}+\varepsilon_{i t}
$$

We fully saturate the model to account for all years before and after the deal date. The omitted category is $\mathbf{1}\{t=-1\}$, reflecting the year prior to deal. All other aspects of the equation are as defined previously. We show the results graphically by plotting the coefficients $\beta_{t}$ for the years immediately around the buyout. In a robustness test, we also show the raw means of key outcome variables for target newspapers in the years around the buyout. 
Although the event studies and other robustness tests allow us to assess pre-trends and rule out certain confounding factors, it remains the case that private equity firms clearly do not pick targets at random, and our empirical design does not approximate a random experiment. Our argument focuses on treatment impacts for the treated, rather than external validity to a random firm in the economy. This interpretation is important for social welfare as private equity expands its footprint in the economy and in the newspaper sector in particular; even to the degree that target newspapers "need" LBOs because they are, for example, mismanaged, we shed light on real outcomes of that buyout.

\section{Private Equity Ownership and Political Outcomes}

As explained in Section 1.1, local newspapers provide residents in the area with key information relevant for civic engagement. People learn from the newspaper-and the TV, radio, and social media sources that subsequently relay this content-about the fact that a local election will occur, who the candidates are, and what, if anything, their platforms contain. As de Benedictis-Kessner and Warshaw (2020) explain, local offices are responsible for providing important local public goods yet their elections are not very salient and, in recent decades, suffer from low turnout. Therefore, the first order question we wish to address in this paper is whether private equity ownership may have real implications in the form of political participation.

To shed light on this question, we examine the association between private equity ownership and local political races. This analysis does not have a strong causal interpretation, primarily because the political data do not permit event studies. Below, we employ data on article content and other operational dimensions of the newspapers to establish a plausible link between ownership type and local political outcomes.

County-Level Elections. The first and main analysis employs county-level election data. We prefer this level of analysis because it is most local and thus should be most closely tied to the local newspaper. We assume that county residents are most likely to read their own county's newspaper for information. At the county level, we consider three types of local elections: legislative councils, mayors, and sheriffs. The broadest coverage exists for council elections, and it is here we find the strongest impacts, shown in columns 1-3 of Panel A in Table 2. First, total votes decline by about 3,000 relative to a mean of about $32,000(9 \%)$ when there is a private equity-owned newspaper in the county. The impact is similar, at 
$12.4 \%$, when we use the log of total votes in column 2. Most important is the third dependent variable, which is turnout measured as the number of votes divided by the county's population. Here we see a decline of $0.82 \%$, which is $9.4 \%$ of the mean. ${ }^{20}$

One way to assess whether these results for legislative council elections are spurious is to test whether effects occur in the same direction for different outcomes. The pattern is similar for mayoral elections, where there is less coverage (Table 2 columns 4-6). Total votes declined by $16 \%$, and turnout also appears to decline, though this effect was not significant. In Appendix Table A.1 Panel A, we further consider sheriff elections. Here we have far fewer observations, and the results are not statistically significant. However, the coefficients are negative across all models. For example, in column 1 the nearly-significant coefficient implies a decline of $7 \%$ in sheriff election votes.

Survey Responses. In Panel B of Table 2, we consider a different type of real political outcome, information about news interest and political engagement based on survey responses in the Cooperative Congressional Election Study (CCES), across 2006-2019. For these survey data, the unit of observation is the county-year level, so we consider treatment at that level. This requires aggregating multiple counties with multiple papers into districts. This is also true for the election data below.

First, we ask whether private equity buyouts lead to a change in interest in news generally. We find that they do not (column 1), although the coefficient is negative. Next, we ask whether the individual has an opinion about the elected official who represents them in the U.S. House of Representatives. Here we find a strong impact; having a private equity-owned paper in the county increases the chances of "No Opinion" by 2 percentage points, about $11 \%$ of the mean. As a control comparison, we consider in columns 3-5 higher levels of government, which are more likely to be independently covered by TV and other news outlets (Senator, Governor, and President). In all cases, there are no effects. These results support those in Table 2 Panel A.

State Legislative Elections. We also consider two supplementary types of elections. The first is for state legislatures (typically called state houses, state senates, or state assemblies) at the district-year level. While the legislature is state-wide, districts elect their own representatives and we expect local newspaper coverage to be relevant for citizens' information sets about these offices. The results are in Table 3 Panel

\footnotetext{
${ }^{20} \mathrm{We}$ do not show visual event studies for these outcomes because of the nature of the county-year level election data, where observations occur only every two to four years in a given locality. In practice, like the other outcomes they contain no pre-trends, but are very noisy and thus not especially informative.
} 
A. We control for the estimated log population of the district and the number of seats up for election. We consider four outcome variables. The first, in column 1, is the number of votes in the election. We find that private equity ownership is associated with a $1.6 \%$ decline in the number of votes, a result that is highly significant. (Unfortunately, turnout is not observable because data on registered voters does not exist at this geographic level.)

Next, we turn to competitiveness measures, which are important signals of a functioning democratic process; the number of candidates and election closeness. The chance that the election has only one candidate increases (Table 3 Panel A column 2), though this result is noisy. We find a similar result when we use the number of candidates (not reported). The outcome in column 3 is an indicator for a close election, defined as the difference between the percent of the vote going to the winner and to the runner up being less than 5\%. This declines by 1.7 percentage points, which is $27 \%$ of the mean. Last, column 4 reports a continuous measure of election closeness, the difference between the percent of the vote going to the winner and to the runner up. This has a positive coefficient, which is just barely not significant, indicating that when there are more private equity-owned papers, winners win by relatively more of the vote. Overall, we see a decline in voting and in election competitiveness, consistent with lower local civic engagement.

Congressional Elections. The last type of election we study are Congressional elections, which are observed at the Congressional district-Congress level. ${ }^{21}$ The results are in Table 3 Panel B. We first consider total votes, which decline following a private equity acquisition by $1.7 \%$. Similarly, turnout (votes as a share of the population eligible to vote) declines by $0.4 \%$, a result that is significant at the $5 \%$ level (column 2). These results clearly point to less political participation. The declines are driven primarily by a decline in votes for the Democratic party, whose share of votes goes down by 2.1 percentage points, or about $5 \%$ of the mean (column 3 ).

Here we also have two measures of election competitiveness. The first is whether the election is uncontested. The chances of an uncontested election increase (column 4), albeit not significantly. Second, we employ an indicator for the incumbent winning reelection, where reelection points to less

\footnotetext{
${ }^{21}$ Each Congress lasts for two years, so this is a unit of time that is coarser than the year. Therefore, in the regression models we include Congress and Congressional district fixed effects. (As above, turnout is not observable because data on registered voters does not exist at this level.) Again, we employ an indicator for the district having a paper that is private equity-owned in the given year.
} 
competitiveness. ${ }^{22}$ Here, we find a robust impact of 11 percentage points, which is $13 \%$ of the mean (column 5). Finally, we examine the number of bills that a member proposes as a measure of their contribution to policymaking. We find in column 6 that this declines by 1.1 , which is about $10 \%$ of the mean. In sum, the results in this panel suggest lower voter engagement, less competitive elections, and less pressure to govern on the sitting House member.

\section{Operational Impacts of Private Equity Ownership}

In this section, we examine channels for the political engagement results above and explore how operations change at private equity-owned newspapers.

News Content. Our first operational outcome is the share of news articles mentioning local policy issues. In Table 4, we assess the impacts of buyouts on the share (Panel A) and the number (Panel B) of a newspaper's articles that cover a specific topic. The share measure is informative about the allocation of reader's attention within the newspaper across content types. We find a significant negative impact of private equity buyouts on the share of articles concerning local government policy. Specifically, these decline by 3.6 percentage points, or $10.8 \%$ of the mean (Panel A column 1). There is also a negative impact on the share of articles that are obituaries, which is $9.4 \%$ of the mean (Panel A column 2). These results suggest that reader attention is diverted away from local content.

In Panel B, we continue to see significant declines in local content when measured as the absolute number of articles. There is a $23 \%$ decline in local government articles and a $29 \%$ decline in obituaries (columns 1-2). Note we report the exponentiated coefficients when the outcome is logged. ${ }^{23}$ More articles on other topics do not compensate for these negative effects. Instead, we see a $16.7 \%$ decline in the total number of articles (column 5).

We next consider content that can be more easily shared across newspapers, creating opportunities for cost efficiencies. Here we find an increase in the share of articles about national politics of 1.3 percentage points or $8.3 \%$ of the mean (column 3). In contrast, there is no change in the number of Associated Press articles (column 4), suggesting that private equity ownership does not lead to more use of national wire services. When it comes to the number of articles, we see no significant impacts

\footnotetext{
${ }^{22}$ The sample size is smaller because we use a different data source for columns 5-6, as described in Section 2.3.

${ }^{23}$ For example, in the case of local government articles we calculate the effect as $23=(\exp (-0.256)-1) \times 100$.
} 
on national politics, and a negative impact on Associated Press articles (Panel B columns 3-4). Overall, these changes in article content are consistent with cost-cutting measures by private equity firms, because they disproportionately reduce articles which are more expensive to produce (i.e., local journalism) while shifting towards national content which is easier to share across newspapers.

Figure 3 Panels $\mathrm{A}-\mathrm{C}$ presents the event study difference-in-differences results. We find minimal pre-trends before the deal, none of which are statistically significant. In the years immediately following the deal year, the coefficients for local content (local government and obituaries) drop discontinuously (Panels A and B), while there is an upward trend for national politics (Panel C). The event study supports the assumption that the impacts we observe in Table 4 are unlikely to be driven by pre-existing trends in local content shifting, and instead can be attributed to changes to private equity operations beginning in the years after the deal.

We consider supplementary outcomes in Appendix Table A.2. We see no change in the share but a significant decline in the raw number of articles about school policy. The absence of an effect on share could reflect substantial demand among readers for information about local schools, where the importance of knowledge may be more immediately salient, especially for parents. We do not see significant impacts on articles about China or Russia. The visual event studies for these outcomes as well as for AP Wire content share are in Appendix Figure A.3. A complication for the AP Wire outcome is that use of wire services trends down in our sample over time. As a result, control newspapers, included in the -1 years before the deal, push the coefficient on that control year upwards. We also report the visual event studies for all outcomes using the log number of articles in Appendix Figure A.2. The regression results for school policy content should be taken with some caution, as we do not see a meaningful impact in the event study.

Employment. We next assess a plausible mechanism which would result in decreases in local news coverage: changes in employment. In Table 5, we consider the log number of employees at the newspaper using the LinkedIn data. We find large and statistically significant decreases in key occupations associated with generating new, local content.

Specifically, following private equity buyouts the number of reporters declines by $7.3 \%$, though this impact is significant only at the .1 level (column 1). The number of editors, who would typically be more highly paid, declines by $8.9 \%$ (column 2 ). This impact is particularly robust, significant at the 
.01 level. We see no impact of private equity buyouts on the number of interns and freelancers, who are typically less costly, as they earn less per hour, do not receive benefits, and do not have long-term contracts. As we would expect, the number of total employees also declines, by $7.1 \%$ (column 4 ). The event studies analysis in Figure 3 Panels D-F confirm these impacts. The plots reveal a steady and statistically significant decrease in employment in the years after a buyout and exhibit no evidence of pre-trends in the years prior to the buyout.

The employment impacts, combined with the decline in absolute local news coverage, suggest that private equity owners reduce costs by cutting local reporting staff. The near-zero marginal cost of nonlocal news dissemination may allow the private equity-owned newspapers to partially make up for the resulting decline in local content with relatively more national content that is syndicated from other newspapers.

Business Platform. We consider variables related to how the newspaper treats demand curves on its two-sided platform in Table 6 Panel A. We find negative impacts on the number of print newspaper subscribers. The data include many instances in which circulation is the same from year-to-year, suggesting imputed and possibly stale data. Therefore, we present two models: one with all the data (Panel A column 1), and one restricted to newspaper-years in which circulation changes from year to year, in case the absence of change represents stale data (Panel A column 2). The results indicate declines of $7.9-11 \%$. In contrast, in column 3 we see a dramatic increase of $44 \%$ in digital circulation, but unfortunately digital circulation is available only for a small subset of the sample. Therefore, we interpret this result with some caution.

The increase in digital subscription raises the question of whether private equity firms select newspapers with low pre-existing digital circulation. To the contrary, Table A.3 shows that private equity investment is weakly associated with higher pre-existing digital shares, using both contemporaneous and lagged ratios of digital to print subscriptions. Rather than purchasing newspapers that have not made the digital transition at all, private equity companies appear to select companies that have partially made the digital transformation, and as a result have some digital subscription share. Returns from incremental investment are potentially the highest for these newspapers. The result is also consistent with our earlier finding that private equity does not seem to focus on especially distressed newspapers. However, at the same time, we do find that the largest increase post-buyout in digital 
subscriptions is coming from newspapers that had relatively lower shares ex-ante (Appendix Table A.4).

One impact of private equity ownership may be to bring the target firm "up to speed" when it comes to IT investment, as in Agrawal and Tambe (2016).

In sum, although private equity acquirers do not target newspapers with low digital circulation, we do find evidence that they invest in increasing it, especially at newspapers with lower levels pre-buyout. However, since digital content typically does not include original reporting that does not appear in print, there is no reason to think a move to digital-though perhaps improving the newspaper's bottom line and helping it survive-would confound our result of less local content and less political participation. Unfortunately, we have poor data coverage on subscriber prices.

Advertisers represent the other side of the newspaper's platform. The impact on the advertising rate appears negative but is imprecisely measured (Table 6 Panel A columns 5-6). Here, we use the same approach to address possibly stale data, though it is more likely that menu costs make advertising rates sticky, as opposed to circulation which we do not expect to be the same year-to-year. The negative impacts on circulation and advertising could reflect private equity owners reducing prices for advertisers to compete with online advertising opportunities, while potentially increasing prices for subscribers. This could increase overall profits if prices rise sufficiently relative to the declines in subscriptions. These results should be interpreted with some caution because while the event studies indicate declines in print circulation and advertising rates, together with an increase in digital circulation, they are noisy (Appendix Figure A.3 Panels D-F).

We find a second benefit of private equity ownership in the form of reduced closure. We consider three outcomes: the newspaper shutting down entirely; merging and changing the newspaper name; and transitioning to a weekly newspaper. All three outcomes represent major changes in newspaper operation. While the annual rates of closure are small, we find that private equity-owned newspaper are much less likely to close newspapers. The results are reported in Table 6 Panel B. Column 2 shows that within year and state, private equity-owned newspapers are $0.2 \%$ less likely to shut down, relative to a mean of $0.4 \%$, implying a $75 \%$ reduction relative to the mean. They are also $60 \%$ less likely to become a weekly newspaper (relative to the mean, column 4). In contrast, we find no evidence that private equity ownership leads to a "rolling up" of newspapers into single entities with the same name, shown in column 3. We can calculate what this result means for averted closures. If private equity-owned 
newspapers closed at the same rate as other newspapers, there would be about 11 additional closures, which is just $0.7 \%$ of the overall sample of 1,610 newspapers. ${ }^{24}$

\section{Mechanisms}

In this section, we consider a number of mechanisms that may explain the association of private equity ownership and political outcomes documented in Section 4. Some of the mechanisms are alternatives to the operational drivers identified in Section 5. Others could coexist with them.

Changing Local Preferences. Private equity-owned newspapers may cater more to local or national changes in news interest. In this case, the political outcomes and article content changes may reflect local demand rather than information supply. That is, if local residents have become less interested in local government, it is possibly that they simultaneously change their voting behavior while private equity-owned newspapers respond better to their preferences for alternative content, rather than the new ownership playing a role in causing the changes in political participation. To test this hypothesis, we employ data from Google Trends on local internet searches for the same keywords that define the local government and national politics content in our analysis above. Google Trends measures are relevant to economic and political realities in the U.S. (Choi and Varian, 2012; Stephens-Davidowitz, 2014; Chae et al., 2015). If people become less interested in local government around the time of the buyout for other reasons, we ought to see a similar result using these Google Trends keywords.

The Google Trends data are composed of time series indices of the volume of search queries that Google users make in a DMA. Google aggregates queries into "terms" and "topics." We can identify all of our keywords as either a term or topic in Google Trends, with exact matches. The index provided for each keyword is based on the share of queries in the DMA for that keyword. We then download the data as a series of cross-sections for each year, so that the measures can be considered residuals after removing year fixed effects. The normalizations mean there is no economic interpretation to the magnitudes; instead the relevant variation is change over time within location.

We use two moments to combine the Google Trends keywords within a DMA-year; the mean and the sum of the indices. Note for article content, we sum the articles containing the keywords within the

\footnotetext{
${ }^{24}$ This reflects the following calculation. Among newspapers that are never private equity-owned, $6.5 \%$ close ultimately. This figure is $2.3 \%$ for private equity-owned newspapers. $6.5 \%$ of the 262 ever private equity-owned newspapers is 17 , minus the actual six ever-private equity closures yields 11 .
} 
newspaper-year. We then use these Google Trends Local Government and National Politics variables as outcomes in our main estimation approach using Equation 1. The average effects are reported in Table 7. We find that searches for local government content increase after buyouts, while there is no effect for national politics content. Specifically, both the mean and the sum of the local government keywords search intensity increase by $2.6 \%$ of their respective means (columns 1-2 of Table 7). Event studies are shown in Appendix Figure A.6.

The positive impact on Google searches for local government content suggests that consumers may seek online sources to substitute for less access to local government content in their newspaper. Since the political outcomes show declining engagement, such substitution efforts appear ineffective, consistent with the evidence from social media research in Section 1.1, including Allcott and Gentzkow (2017). Regardless of any substitution effort, however, we can rule out meaningful negative impacts on Google queries for local government content, offering compelling evidence against changing local preferences as a confounder of our main results. These analytical results are supported by a recent national survey data finding strong interest in local relative to national news, especially among young people. ${ }^{25}$

Survivorship. In Section 5, we showed that private equity ownership is associated with a lower chance of newspaper closure. This raises the possibility that the political results reflect survivorship; perhaps all survivors shift operations, for example away from local government content, and experience civic engagement declines in the local area. To test this, we can restrict the analysis sample to surviving newspapers only, defined as those that persist to the end of our sample.

The results for article content and employees among surviving newspapers, reported in Appendix Table A.5 and A.6 Panel A, are very similar to the main results in Tables 4 and 5. In line with these operational results, we continue to find an association for the political outcomes in Appendix table A.7 Panel A which is, if anything, stronger than the main results in Table 2. A related concern may be that the results are tied to a shift to digital content as well as survival, and reflect private equity owners being more likely to deploy digital content in order to survive. Therefore, in Appendix Tables A.6 Panel B, A.7 Panel B, and A.8, we further restrict the sample to newspapers that not only survived but also have digital circulation. Although the sample size becomes quite small, the results are qualitatively preserved.

\footnotetext{
${ }^{25}$ A national poll from Spring 2022 found sizable interest among young people (18-to-29-year-olds) for local news coverage relative to national news or social media. Data and results available here: https://iop.harvard.edu/youth-poll/ spring-2022-harvard-youth-poll.
} 
In sum, neither differential survival nor digital content seem to explain the political associations and operational drivers.

Ownership Types Beyond Private Equity. To understand how private equity fits into the industry's broader context and to assess whether its impacts reflect corporatization or scale, it is useful to explore its relation to other ownership types. As depicted in Figure 2 Panel B, 31\% of newspaper-years in our sample occur under family ownership, $21 \%$ under private chain ownership, $14 \%$ under public ownership, $16 \%$ under independent ownership, and 9\% under non-PE financial ownership. In this section, we first compare private equity with these other major ownership types, and then study how the impacts of private equity acquisitions vary depending on the previous ownership type.

In Table 8, we compare different ownership types. In all cases, the base (omitted) group is private equity, so the coefficients should be interpreted relative to private equity. We show two models for each outcome. The first excludes newspaper fixed effects, so each coefficient represents the average for that ownership type relative to private equity. The second column includes newspaper fixed effects, so the coefficient is identified only from newspapers that change to or from the ownership type, but is still relative to private equity. We report the results for all of our main outcomes across the four panels of Table 8. All other ownership types on average have significantly higher election participation, local government article content, and employment (for example, column 1 of Panel A and column 5 of Panel B). Other financial firms are the exception in not having significantly different employment on average compared to private equity (bottom row of columns 1, 3, and 5 of Panel C). On average other ownership types have less digital circulation, more overall circulation, and are more likely to close (Panel D).

In the models with newspaper fixed effects, where we consider the impact of transitions to these other ownership types relative to private equity as the base group, we find that transitions to independent and family ownership are accompanied by significant increases in both the share and number of articles about local government (Table 8 Panel B columns 2 and 6). The patterns are similar for employment, with transitions to independent ownership leading to about a $10 \%$ increase in the number of reporters, for example (Panel C).

We also assess whether the impacts are stronger for particular previous ownership types, including all of them in the same model to facilitate comparison. This analysis is challenged by the relatively small sample size, making it more difficult to identify significant impacts when we split the main 
independent variable into categories. The results are in Appendix Tables A.9-A.12. Overall, no one type of ownership appears to explain the key outcomes, though the coefficients vary substantially in magnitude and significance. Family and public ownership seem to be the previous types that are associated with the largest negative impact on local government news, though private chain also has a negative coefficient. Also, transitions from publicly traded and private chain newspapers are associated with the most negative impacts on employment outcomes. ${ }^{26}$

In sum, this analysis is generally consistent with our main results, suggesting that alternative ownership types are associated with more local news coverage, more newspaper employment, and higher local voter turnout, but also lower digital circulation and higher closure rates. These results are relevant to understanding ownership types in media. First, private equity ownership impacts newspapers in ways that are not mirrored by any other ownership type, suggesting the main results do not simply reflect corporatization or scale. To the contrary, public firms and chains are associated with significantly more employees and local government news coverage. Second, our results add to the existing literature on family firms. This is particularly relevant because family ownership has traditionally been a dominant form for newspapers worldwide. Consistent with non-pecuniary benefits from governance that family ownership might entail, family firms do have more employees, especially senior ones. This contributes to the debate in the literature about labor contracts in family firms (Bertrand and Schoar, 2006; Villalonga and Amit, 2006; Sraer and Thesmar, 2007; Bach and Serrano-Velarde, 2015).

Targeting. Beyond the type of previous ownership discussed above, it may be that private equityowned newspapers have different outcomes because of selection; that is, private equity firms may target newspapers that are doing especially well or poorly on various dimensions. One hypothesis is that private equity firms purchase struggling papers. Alternatively, these investors may seek out newspaper groups that have the assets or sales to support changes in capital structure. Despite the absence of pre-trends in the event studies, such targeting could play a role in explaining the results. In addition to this mechanism test, it is independently interesting to explore which characteristics predict private equity buyouts.

In Table 9 we consider predictors of private equity ownership. The dependent variable is a binary indicator that equals one if a newspaper-year switches to private equity ownership in that year. For this

\footnotetext{
${ }^{26}$ For robustness, Appendix Table A.13 includes separate regressions for the results for article content for each previous ownership group. The findings are not driven by specific comparisons of private equity against specific omitted categories like other financial firms.
} 
analysis, we omit the paper after that year. We find that private equity tends to target larger firms, in the sense of having more newspapers in the group (column 1). They also target newspapers with higher ex-ante circulation and advertising rates (columns 8-9). These results are not consistent with targeting newspapers in distress. The remaining columns consider our key outcome variables, and do not find any evidence of targeting, for example, on local voter turnout or news interest (columns 2-5). Last, column 10 examines whether private equity targets particular ownership types, with the "Other financial firms" category omitted. As private equity almost never acquires from other financial firms, all the coefficients are positive. The strongest relationship is for public companies, with private chains and family-owned newspapers second.

Discussion. This section has shown that several channels do not fully explain our main results: changes in local interest (i.e., demand), survivorship and digital content, the previous ownership type, and targeting of outcome variables. Instead, our results support a mechanism in which private equity ownership reduces local government content in the newspaper, measured by the content itself and the employment of reporters and editors. In this case, the shift in content causes citizens to be less informed and become less engaged in local democracy. In turn, this reduces participation in local elections and leads to deteriorating democracy, with less competitive elections and more poorly performing elected members of Congress. This link is also supported by the large body of literature establishing that local newspapers in the U.S. have been measurably important to political participation, discussed in Section 1.1. As we discuss in the Conclusion below, welfare effects are beyond the scope of our work, especially because we do find lower rates of newspaper closure under private equity ownership.

\section{Robustness Tests}

In this section, we describe robustness tests of the main political and operational results.

Placebo Test. We conduct a placebo test by randomly allocating PE deals to newspapers and once randomly selected creating a placebo deal year. The random allocation of deal years is disciplined such that the fraction of papers with a placebo PE deal in that year matches the original sample. The results are presented in Table 10. There are no significant impacts across outcome variables. 
Staggered Bias Tests. We conduct robustness with respect to the staggered difference-in-differences empirical design in Table A.14, using the Sun and Abraham (2021) and Callaway and Sant'Anna (2021) estimators. Our coefficients on the impacts of private equity investment on local news content, employment, and circulation maintain the same signs. Our main estimates on article content remain economically and statistically significant. Our estimates on employees and operations are quantitatively very similar but slightly weaker due to power issues in the specification, and our magnitudes remain substantial.

Machine Learning Measures of Article Content. To provide alternative measures of article content and ensure that the main results do not spuriously result from a particular researcher-chosen word or words, we use a machine learning approach to classify local and national content. We do so using the full-text newspapers from the Chicago Tribune and the Boston Globe downloaded from LexisNexis Uni, which contain articles classified into "local" and "national" sections. We implement a tf-idf (term frequency - inverse document frequency) process to identify the words most associated with local and national content. This is a popular machine learning algorithm commonly used to identify the word associations most commonly associated with a particular corpus of text relative to a reference dataset. Other papers which have used this methodology include Gentzkow et al. (2019), Doh et al. (2022), and Kelly et al. (2021). ${ }^{27}$

We find that private equity buyouts are associated with large, and typically statistically significant, declines in local content for this new measure of local keywords. The results for the top 15 local keywords are reported in Appendix Table A.15. Interestingly, we also observe some declines in national keywords in Appendix Table A.16, particularly those which may be politically relevant (i.e., "administration" and "voters"). By contrast, we observe far smaller declines for other national keywords, including some words which are related to foreign conflict (i.e., "Baghdad" or "troops"). This overall pattern supports our central story that private equity buyouts affect local politically relevant news content; our results are robust to alternative choices of words. We prefer the researcher-led set of words used in our main

\footnotetext{
${ }^{27}$ Specifically, for every word $j$ in document $i$, the term frequency $t f_{i j}$ counts the frequency of word $i$ 's appearance in document $i$. The inverse document frequency is the log of the number of documents divided by the documents containing the word $j: i d f_{i j} \equiv \log \left(n / d_{j}\right)$ with $n$ being the number of documents and $d_{j}$ being the count over documents containing $j$. We are interested in $t f_{i j} \times i d f_{i j}$ : words that are common in our document, but uncommon in the set of comparison documents. Our algorithm, in other words, provides an estimate of the idiosyncratic words commonly and distinctly found in both local and national newspaper sections. It provides therefore an alternative, machine learning-generated measure of local and national news content.
} 
approach because the words are more closely connected to our primary research question, which is about how local government content affects political participation.

Leave-one-out Content Test. To ensure that the results do not reflect one specific keyword used to construct the content measures, we conduct leave-one-out robustness tests of the content measures. We estimate multiple models, in which each model shows the effect on the number of articles mentioning all the keywords except the one identified in the column header. The results are in Appendix Tables A.17, A.18, and A.19 for local, national, and obituary content, respectively. The results are generally robust to omitting any given word and the magnitudes are typically a bit smaller but quite similar to the main combined coefficient. The one exception is for the share of articles that are obituaries (Appendix Table A.19 Panel A), where we do not have significance if we omit "died" or "passed away." This is not unexpected, since it is naturally rare to write an obituary without including these terms.

Raw Mean Changes. We examine the raw mean changes in key variables around buyouts, within the target sample of firms. Observing similar results using this simple event study confirms that nothing about our parametric models biases the general direction of effects. Appendix Figure A.4 shows the mean of the outcome variable for each year around the year of the buyout for four key variables. Panel A contains the share of articles on local government. Similar to the dynamic difference-in-differences results, we see no pre-trends and a discontinuous decline after the buyout. In Panel B, the share of articles on national politics does not exhibit the same strong upward trend, suggesting that the comparison with other newspapers is important to the regression estimate. Newspapers have generally increased their national content over time, which muddies the waters for this figure. For employees, we observe a marked decline in the first three years after the buyout (Panel C). Last, in Panel D, there is a significant decline in circulation after the buyout, which appears to begin in year three, but we also see some evidence of the pre-trend discussed previously. This is helpful given the noise in the dynamic difference-in-differences model (Figure A.3 Panel D).

Specification and Fixed Effect Tests. We consider a range of alternative models to address potential concerns with the specification. First, we partially address endogeneity in acquisition by private equity by adding deal fixed effects in Appendix Table A.20. This specification allowed us to control for all unobserved characteristics in common with newspapers commonly purchased (at the potential cost of 
"overcontrolling" for part of the treatment effect itself). Despite the strong nature of this control, we continued to observe large changes for all our main outcome variables.

There may be concern with binary outcome variables in a panel data setting. To address this, in Appendix Table A.21 Panel A, we report the article content results using a fractional logit GLM, following Papke and Wooldridge (2008). The results are robust to this approach, and the effect on news content about international issues (using the words "China" and "Russia" as a proxy) grows stronger (column 3). A second concern with the content results is that given the different match rates to employment and article data, our employment results could stem from a different set of newspapers than the content results. In Appendix Table A.21 Panel B, we show that the effects on local governance article content are robust to restricting the sample to those papers in which we also observed employment, though the national politics result is not. We also show that the results in which we log the outcome variables are robust to using levels in Appendix Table A.22.

We also conduct a robustness test of the political participation results. We are concerned that because these outcomes are defined at the county level, and there may be more than one newspaper in a county, it is possible that our results reflect some spurious factor at the county level. Therefore, in Appendix Table A.1 Panel B, we add county level fixed effects and remove newspaper fixed effects. The results become weaker without the newspaper fixed effects. However, the coefficients remain large and negative, and the key county council turnout impact remains significant at the 0.1 level.

Finally, we conduct heterogeneity tests to better understand which parts of the sample drive the main effects on employment and local government news content. One reason this is important is that since our results are estimated in-sample on the set of newspapers targeted by private equity firms, they may not generalize broadly to the set of all newspapers - that is, in a counterfactual experiment where private equity investors randomly acquired newspapers. We therefore divide the sample around the median in two dimensions. The first is on print circulation, where we take the average for each newspaper across its life and then calculate the median across newspapers. The second dimension is local news share, which is the ratio of news items which are local compared with national news. We similarly compare newspapers that are below and above median in this local news ratio across their life. Panel A of Table A.23 shows that private equity ownership reduces employment more at newspapers with a smaller local news share and below-median circulation. Panel B shows that local government news content is more 
negatively affected at newspapers with below-median circulation but above-median local news shares. These results suggest that the consolidation motives for private equity may be felt especially strongly for papers at a smaller scale, and which were previously supplying a high degree of local news content.

Overall, these tests together with the dynamic difference-in-differences event studies support the main results on news content and employees. The operational results around circulation and closure are less compelling, because either the event study or control test is suggestive of a pre-trend, or the event study does not clearly indicate a discontinuous change post-buyout. We are more confident in the political participation results, as they offer consistent results in terms of coefficient direction across many alternative outcomes that are measured at different times and using different geographies. They are, however, sparse and somewhat noisy, and do not permit event studies, which means they do not have as strong of a causal interpretation.

\section{Conclusion}

The importance of media to political outcomes in the U.S. has never been more apparent. The newspaper industry has been in decline for decades, and newspaper failures have accelerated over the past ten years. These failures have generated substantial alarm among political scientists; for example, following the January 2021 insurrection at the U.S. Capitol, Timothy Snyder wrote that "the financial crisis of 2008 did to American newspapers what the Great Depression did to German ones" (Snyder, 2021). While there has been work on the role of partisan ownership (DellaVigna and Kaplan, 2007), and despite a large literature on the role of competition in media markets, including Cagé (2020), there has been little focus on how the intensity of profit-maximizing incentives affects information provision. In this paper, we examine the role of private equity ownership, which has exceptionally high-powered and short-term incentives to increase firm value. We offer to our knowledge the first evidence of private equity's impact on the media industry.

We document declines in civic engagement and political participation following local newspaper shifts to private equity ownership. As a likely channel for this relationship, we find declines in news content about local government (but not national or international content, which is more easily syndicated across newspapers). The absolute amount of local news declines as well. We also observe falling employment of editors and reporters, who represent a significant share of newspaper costs and 
are necessary to produce timely, informative articles about local government.

This civic engagement result is unambiguously negative, as voter knowledge of local policy issues and participation in the political process are crucial for local government accountability and, ultimately, a functioning democracy. Further research is needed both to confirm our results using higher-quality data on outcomes and to understand whether alternative business models being suggested for the newspaper industry, such as non-profits — as exemplified by the Salt Lake Tribune's conversion in 2019—might be able to achieve better outcomes (Times, 2020). 


\section{References}

Abramowitz, Alan I and Steven Webster, "The rise of negative partisanship and the nationalization of US elections in the 21st century," Electoral Studies, 2016, 41, 12-22.

Acharya, Viral V, Oliver F Gottschalg, Moritz Hahn, and Conor Kehoe, "Corporate governance and value creation: Evidence from private equity," The Review of Financial Studies, 2013, 26 (2), 368-402.

Agrawal, Ashwini and Prasanna Tambe, "Private equity and workers' career paths: The role of technological change," The Review of Financial Studies, 2016, 29 (9), 2455-2489.

Allcott, Hunt and Matthew Gentzkow, "Social media and fake news in the 2016 election," Journal of economic perspectives, 2017, 31 (2), 211-36.

_ , Luca Braghieri, Sarah Eichmeyer, and Matthew Gentzkow, "The welfare effects of social media," American Economic Review, 2020, 110 (3), 629-76.

Almond, Douglas, Hilary W Hoynes, and Diane Whitmore Schanzenbach, "Inside the war on poverty: The impact of food stamps on birth outcomes," The Review of Economics and Statistics, 2011, 93 (2), 387-403.

Angelucci, Charles, Julia Cagé, and Michael Sinkinson, "Media Competition and News Diets," Technical Report, National Bureau of Economic Research 2020.

Ardia, David, Evan Ringel, Victoria Smith Ekstrand, , and Ashley Fox, "Addressing the decline of local news, rise of platforms, and spread of mis- and disinformation online," UNC Center for Media Law and Policy, 2020.

Autor, David H, "Outsourcing at will: The contribution of unjust dismissal doctrine to the growth of employment outsourcing," Journal of labor economics, 2003, 21 (1), 1-42.

Axelson, Ulf, Tim Jenkinson, Per Strömberg, and Michael S Weisbach, "Borrow cheap, buy high? The determinants of leverage and pricing in buyouts," The Journal of Finance, 2013, 68 (6), 22232267.

Bach, Laurent and Nicolas Serrano-Velarde, "CEO identity and labor contracts: Evidence from CEO transitions," Journal of Corporate Finance, 2015, 33, 227-242.

Bakshy, Eytan, Solomon Messing, and Lada A Adamic, "Exposure to ideologically diverse news and opinion on Facebook," Science, 2015, 348 (6239), 1130-1132.

Barthel, Michael, Jesse Holcomb, Jessica Mahone, and Amy Mitchell, "Civic engagement strongly tied to local news habits," Pew Research Center. Accessed September, 2016, 10, 2019.

Bernstein, Shai and Albert Sheen, "The operational consequences of private equity buyouts: Evidence from the restaurant industry," Review of Financial Studies, 2016, 29 (9), 2387-2418.

Berry, William D, Richard C Fording, Evan J Ringquist, Russell L Hanson, and Carl E Klarner, "Measuring citizen and government ideology in the US states: A re-appraisal," State Politics \& Policy Quarterly, 2010, 10 (2), 117-135.

Bertrand, Marianne and Antoinette Schoar, "The role of family in family firms," Journal of economic perspectives, 2006, 20 (2), 73-96.

Boucly, Quentin, David Sraer, and David Thesmar, "Growth LBOs," Journal of Financial Economics, 2011, 102 (2), 432-453.

Brav, Alon, Wei Jiang, and Hyunseob Kim, "The real effects of hedge fund activism: Productivity, asset allocation, and labor outcomes," The Review of Financial Studies, 2015, 28 (10), 2723-2769.

Bursztyn, Leonardo, Georgy Egorov, Ruben Enikolopov, and Maria Petrova, "Social media and xenophobia: evidence from Russia," Technical Report, National Bureau of Economic Research 2019.

Cagé, Julia, Saving the media, Harvard University Press, 2016.

_ , "Media competition, information provision and political participation: Evidence from French local newspapers and elections, 1944-2014,” Journal of Public Economics, 2020, 185, 104077. 
Callaway, Brantly and Pedro HC Sant'Anna, "Difference-in-differences with multiple time periods," Journal of Econometrics, 2021, 225 (2), 200-230.

Carpenter, Jennifer $\mathbf{N}$, "Does option compensation increase managerial risk appetite?," The Journal of finance, 2000, 55 (5), 2311-2331.

Chae, David H, Sean Clouston, Mark L Hatzenbuehler, Michael R Kramer, Hannah LF Cooper, Sacoby M Wilson, Seth I Stephens-Davidowitz, Robert S Gold, and Bruce G Link, "Association between an internet-based measure of area racism and black mortality," PloS one, 2015, 10 (4), e0122963.

Choi, Hyunyoung and Hal Varian, "Predicting the present with Google Trends," Economic record, 2012, 88, 2-9.

Cohn, Jonathan, Nicole Nestoriak, and Malcolm Wardlaw, "Private equity buyouts and workplace safety," Working Paper, 2017.

Darr, Joshua P, Matthew P Hitt, and Johanna L Dunaway, "Newspaper closures polarize voting behavior," Journal of Communication, 2018, 68 (6), 1007-1028.

Davis, Steven J, John C Haltiwanger, Kyle Handley, Ben Lipsius, Josh Lerner, and Javier Miranda, "The economic effects of private equity buyouts," Technical Report, National Bureau of Economic Research 2019.

_ , John Haltiwanger, Kyle Handley, Ron Jarmin, Josh Lerner, and Javier Miranda, "Private equity, jobs, and productivity," The American Economic Review, 2014, 104 (12), 3956-3990.

de Benedictis-Kessner, Justin and Christopher Warshaw, "Politics in forgotten governments: the partisan composition of county legislatures and county fiscal policies," The Journal of Politics, 2020, $82(2), 460-475$.

DellaVigna, Stefano and Ethan Kaplan, “The Fox News effect: Media bias and voting," The Quarterly Journal of Economics, 2007, 122 (3), 1187-1234.

_ , Ruben Enikolopov, Vera Mironova, Maria Petrova, and Ekaterina Zhuravskaya, "Cross-border media and nationalism: Evidence from Serbian radio in Croatia," American Economic Journal: Applied Economics, 2014, 6 (3), 103-32.

Djankov, Simeon, Caralee McLiesh, Tatiana Nenova, and Andrei Shleifer, "Who owns the media?," The Journal of Law and Economics, 2003, 46 (2), 341-382.

Doh, Taeyoung, Dongho Song, and Shu-Kuei Yang, "Deciphering federal reserve communication via text analysis of alternative fomc statements," Federal Reserve Bank of Kansas City Working Paper Forthcoming, 2022.

Drago, Francesco, Tommaso Nannicini, and Francesco Sobbrio, "Meet the press: How voters and politicians respond to newspaper entry and exit," American Economic Journal: Applied Economics, 2014, 6 (3), 159-88.

Durante, Ruben, Paolo Pinotti, and Andrea Tesei, "The political legacy of entertainment tv," American Economic Review, 2019, 109 (7), 2497-2530.

Dyck, Alexander, Natalya Volchkova, and Luigi Zingales, "The corporate governance role of the media: Evidence from Russia,” The Journal of Finance, 2008, 63 (3), 1093-1135.

Eaton, Charlie, Sabrina Howell, and Constantine Yannelis, "When investor incentives and consumer interests diverge: Private equity in higher education," The Review of Financial Studies, 2019.

Enikolopov, Ruben, Alexey Makarin, and Maria Petrova, "Social media and protest participation: Evidence from Russia," Econometrica, 2020, 88 (4), 1479-1514.

_ , Maria Petrova, and Ekaterina Zhuravskaya, "Media and political persuasion: Evidence from Russia," American Economic Review, 2011, 101 (7), 3253-85.

Falck, Oliver, Robert Gold, and Stephan Heblich, "E-lections: Voting Behavior and the Internet," 
American Economic Review, 2014, 104 (7), 2238-65.

Fan, Ying, "Ownership consolidation and product characteristics: A study of the US daily newspaper market," American Economic Review, 2013, 103 (5), 1598-1628.

Ferraz, Claudio and Frederico Finan, "Exposing corrupt politicians: the effects of Brazil's publicly released audits on electoral outcomes," The Quarterly journal of economics, 2008, 123 (2), 703-745.

Filla, Jackie and Martin Johnson, "Local news outlets and political participation," Urban Affairs Review, 2010, 45 (5), 679-692.

Fracassi, Cesare, Alessandro Previtero, and Albert W Sheen, "Barbarians at the store? Private equity, products, and consumers," Technical Report, National Bureau of Economic Research 2020.

Gao, Janet, Merih Sevilir, and Yong Seok Kim, "Private equity in the hospital industry," Technical Report 7872021.

Gao, Pengjie, Chang Lee, and Dermot Murphy, "Financing dies in darkness? The impact of newspaper closures on public finance," Journal of Financial Economics, 2020, 135 (2), 445-467.

Gavazza, Alessandro, Mattia Nardotto, and Tommaso Valletti, "Internet and politics: Evidence from uk local elections and local government policies," The Review of Economic Studies, 2019, 86 (5), 2092-2135.

Gentzkow, Matthew, "Television and voter turnout," The Quarterly Journal of Economics, 2006, 121 (3), 931-972.

_ and Jesse M Shapiro, "What drives media slant? Evidence from US daily newspapers," Econometrica, 2010, 78 (1), 35-71.

_ , Bryan Kelly, and Matt Taddy, "Text as data," Journal of Economic Literature, 2019, 57 (3), 535-74.

_ , Jesse M Shapiro, and Michael Sinkinson, "The effect of newspaper entry and exit on electoral politics," American Economic Review, 2011, 101 (7), 2980-3018.

_, , and _ , "Competition and ideological diversity: Historical evidence from us newspapers," American Economic Review, 2014, 104 (10), 3073-3114.

Gerber, Alan S, Dean Karlan, and Daniel Bergan, "Does the media matter? A field experiment measuring the effect of newspapers on voting behavior and political opinions," American Economic Journal: Applied Economics, 2009, 1 (2), 35-52.

Goetzmann, William N, Jonathan E Ingersoll Jr, and Stephen A Ross, "High-water marks and hedge fund management contracts," The Journal of Finance, 2003, 58 (4), 1685-1718.

Gornall, Will, Oleg Gredil, Sabrina T Howell, and Xing Liu, "Do Employees Cheer for Private Equity? The Heterogeneous Effects of Buyouts on Job Quality," Available at SSRN 3912230, 2021.

Grinblatt, Mark and Sheridan Titman, "Adverse risk incentives and the design of performance-based contracts," Management science, 1989, 35 (7), 807-822.

Groseclose, Tim and Jeffrey Milyo, "A measure of media bias," The Quarterly Journal of Economics, 2005, 120 (4), 1191-1237.

Grossman, Guy, Yotam Margalit, and Tamar Mitts, "Media Ownership as Political Investment: The Case of Israel Hayom," Working Paper, 2020.

Guo, Shourun, Edith S Hotchkiss, and Weihong Song, "Do buyouts (still) create value?," The Journal of Finance, 2011, 66 (2), 479-517.

Gupta, Atul, Sabrina Howell, Constantine Yannelis, and Abhinav Gupta, "Does private equity investment in healthcare benefit patients? evidence from nursing homes," Evidence from Nursing Homes, 2020.

Gurun, Umit G and Alexander W Butler, "Don't believe the hype: Local media slant, local advertising, and firm value," The Journal of Finance, 2012, 67 (2), 561-598.

Hayes, Danny and Jennifer L Lawless, "As local news goes, so goes citizen engagement: Media, 
knowledge, and participation in US House Elections," The Journal of Politics, 2015, 77 (2), 447-462.

_ and _ , "The decline of local news and its effects: New evidence from longitudinal data," The Journal of Politics, 2018, 80 (1), 332-336.

Hopkins, Daniel J, The increasingly United States: How and why American political behavior nationalized, University of Chicago Press, 2018.

Howell, Sabrina T, Yeejin Jang, Hyeik Kim, and Michael S Weisbach, "All Clear for Takeoff: Evidence from Airports on the Effects of Infrastructure Privatization," Technical Report, National Bureau of Economic Research 2022.

Jacobson, Gary C, "It's nothing personal: The decline of the incumbency advantage in US House elections," The Journal of Politics, 2015, 77 (3), 861-873.

Jensen, Michael C and William H Meckling, "Theory of the firm: Managerial behavior, agency costs and ownership structure," Journal of financial economics, 1976, 3 (4), 305-360.

Johnston-Ross, Emily, Song Ma, and Manju Puri, "Private equity and financial stability: evidence from failed bank resolution in the crisis," Technical Report, National Bureau of Economic Research 2021.

Kaplan, Steven N and Per Stromberg, "Leveraged buyouts and private equity," Journal of Economic Perspectives, 2009, 23 (1), 121-46.

Katz, Jonathan N, Gary King, and Elizabeth Rosenblatt, "Theoretical foundations and empirical evaluations of partisan fairness in district-based democracies," American Political Science Review, 2020, 114 (1), 164-178.

Kelly, Bryan, Dimitris Papanikolaou, Amit Seru, and Matt Taddy, "Measuring technological innovation over the long run," American Economic Review: Insights, 2021, 3 (3), 303-320.

Klarner, Carl, "State Legislative Election Returns, 1967-2016: Restructured For Use," 2018.

Kouwenberg, Roy and William T Ziemba, "Incentives and risk taking in hedge funds," Journal of Banking \& Finance, 2007, 31 (11), 3291-3310.

Kuttner, Robert and Hildy Zenger, "Saving the Free Press from Private Equity," The American Prospect, 2017.

Lelkes, Yphtach, Gaurav Sood, and Shanto Iyengar, "The hostile audience: The effect of access to broadband internet on partisan affect," American Journal of Political Science, 2017, 61 (1), 5-20.

Levy, Roee, "Social Media, News Consumption, and Polarization: Evidence from a Field Experiment," American Economic Review, 2020.

Lewis, Adam, "Don't count on private equity to save newspapers," PitchBook, 2018, p. April 27.

Martin, Gregory J and Joshua McCrain, "Local news and national politics," American Political Science Review, 2019, 113 (2), 372-384.

Martin, Nicole, "How Social Media Has Changed How We Consume News," Forbes, 2018.

Moskowitz, Daniel J, "Local news, information, and the nationalization of US Elections," Technical Report, Working Paper, https://bit. ly/2W15rjp 2018.

Müller, Karsten and Carlo Schwarz, "From hashtag to hate crime: Twitter and anti-minority sentiment," Available at SSRN 3149103, 2019.

Palomino, Frédéric and Andrea Prat, "Risk taking and optimal contracts for money managers," RAND Journal of Economics, 2003, pp. 113-137.

Papke, Leslie E and Jeffrey M Wooldridge, "Panel data methods for fractional response variables with an application to test pass rates," Journal of econometrics, 2008, 145 (1-2), 121-133.

Puglisi, Riccardo and James M Snyder, "The balanced US press," Journal of the European Economic Association, 2015, 13 (2), 240-264.

Qin, Bei, David Strömberg, and Yanhui Wu, "Social media, information networks, and protests in 
china," Work. Pap., Stockholm Univ., Stockholm, Swed, 2019.

Romer, Christina D and David H Romer, "Does monetary policy matter? A new test in the spirit of Friedman and Schwartz," NBER macroeconomics annual, 1989, 4, 121-170.

_ and _, "The macroeconomic effects of tax changes: estimates based on a new measure of fiscal shocks," American Economic Review, 2010, 100 (3), 763-801.

Rubado, Meghan E and Jay T Jennings, "Political consequences of the endangered local watchdog: Newspaper decline and mayoral elections in the United States," Urban Affairs Review, 2020, 56 (5), 1327-1356.

Schaub, Max and Davide Morisi, "Voter mobilisation in the echo chamber: Broadband internet and the rise of populism in Europe," European Journal of Political Research, 2019.

Shearer, Elisa and Amy Mitchell, "News Use Across Social Media Platforms in 2020," Pew Research Center, 2021.

Shephard, Alex, "Finance Is Killing the News," The New Republic, 2018.

Smith, Gerry and K Chiglinsky, "Wall Street Has Plans for Newspapers, and They Aren't Pretty," Bloomberg Quint, 2020.

Snyder, James M and David Strömberg, "Press coverage and political accountability," Journal of political Economy, 2010, 118 (2), 355-408.

Snyder, Timothy, "The American Abyss: A historian of fascism and political atrocity on Trump, the mob and what comes next," The New York Times, 2021.

Sraer, David and David Thesmar, "Performance and behavior of family firms: Evidence from the French stock market," Journal of the european economic Association, 2007, 5 (4), 709-751.

Stephens-Davidowitz, Seth, "The cost of racial animus on a black candidate: Evidence using Google search data," Journal of Public Economics, 2014, 118, 26-40.

Strömberg, David, "Radio's impact on public spending," The Quarterly Journal of Economics, 2004, 119 (1), 189-221.

Sun, Liyang and Sarah Abraham, "Estimating dynamic treatment effects in event studies with heterogeneous treatment effects," Journal of Econometrics, 2021, 225 (2), 175-199.

Sunstein, Cass R, \# Republic: Divided democracy in the age of social media, Princeton University Press, 2018.

Times, Los Angeles, "Editorial: Local newspapers are dying. Here's how we can save them," Los Angeles Times, 2020.

Tocqueville, Alexis De, Democracy in america, Regnery Publishing, 1835.

Turkel, Eray, Anish Saha, Rhett Carson Owen, Gregory J Martin, and Shoshana Vasserman, "A method for measuring investigative journalism in local newspapers," Proceedings of the National Academy of Sciences, 2021, 118 (30).

Villalonga, Belen and Raphael Amit, "How do family ownership, control and management affect firm value?," Journal of financial Economics, 2006, 80 (2), 385-417.

Vosoughi, Soroush, Deb Roy, and Sinan Aral, "The spread of true and false news online," Science, 2018, 359 (6380), 1146-1151. 
Figure 1: Private Equity Ownership of Daily Newspapers (2001-2019)

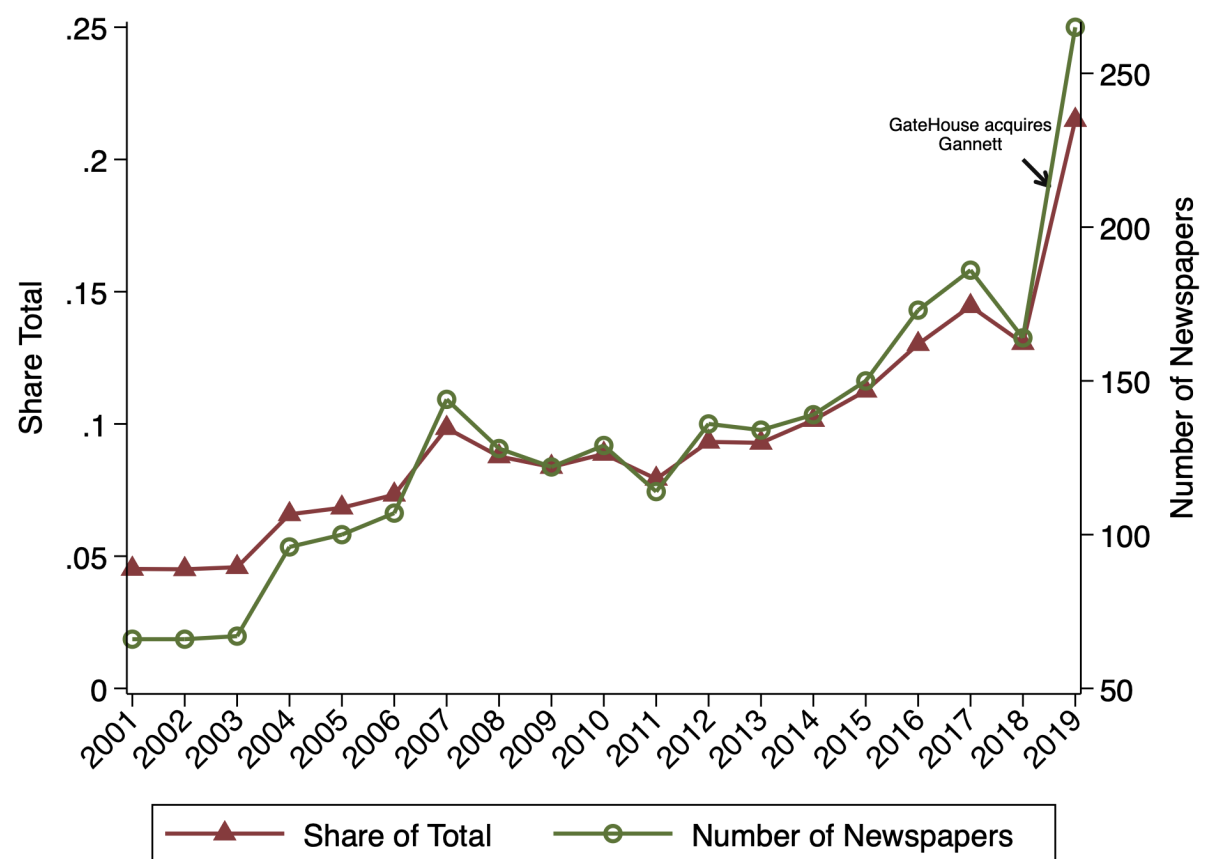

Note: This figure shows the share of all newspapers and the number of newspapers owned by private equity firms over time in our sample of daily newspapers. 
Figure 2: Private Equity Compared with Other Major Ownership Types (2001-2019)

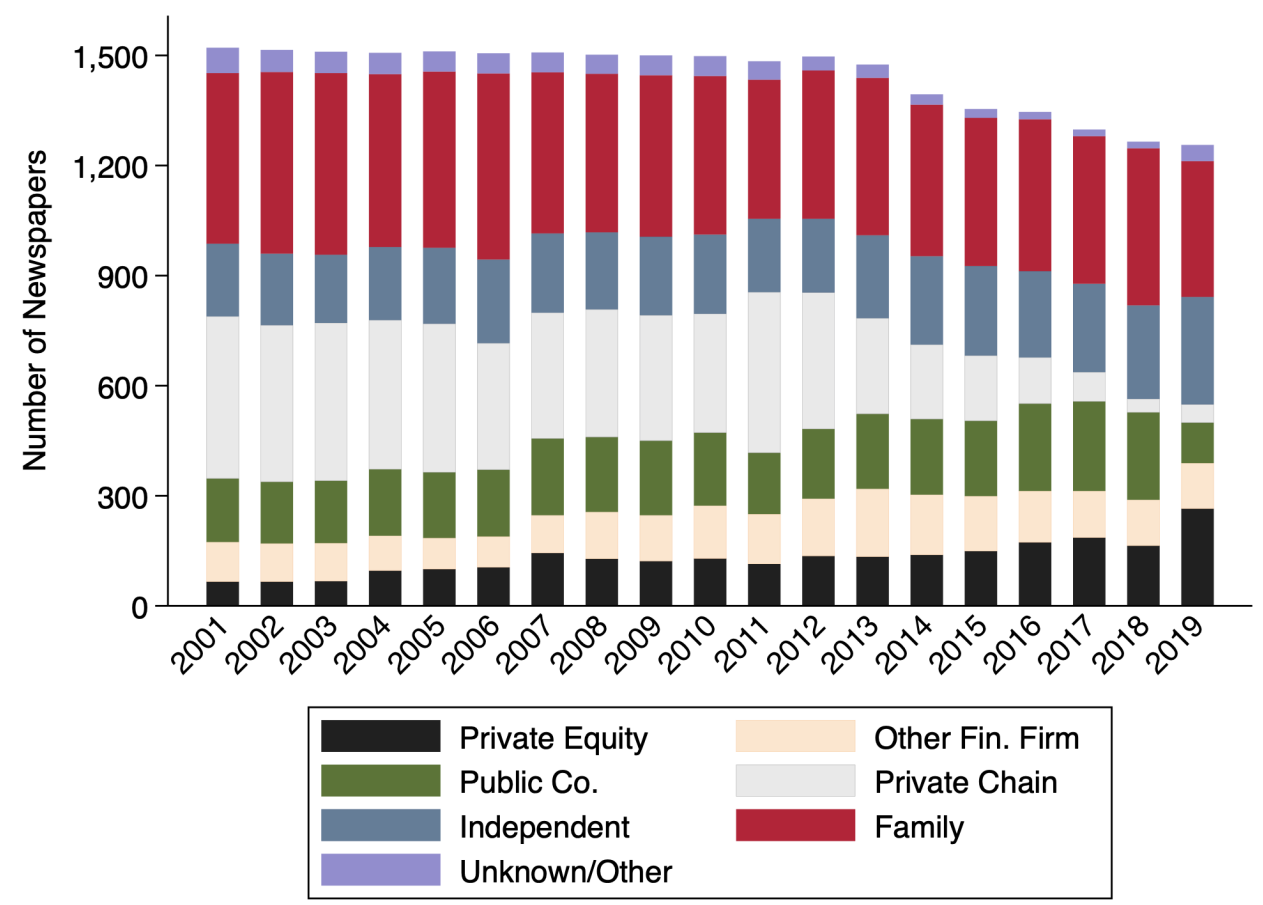

A. Major Ownership Types as Fraction of Total in Study Sample

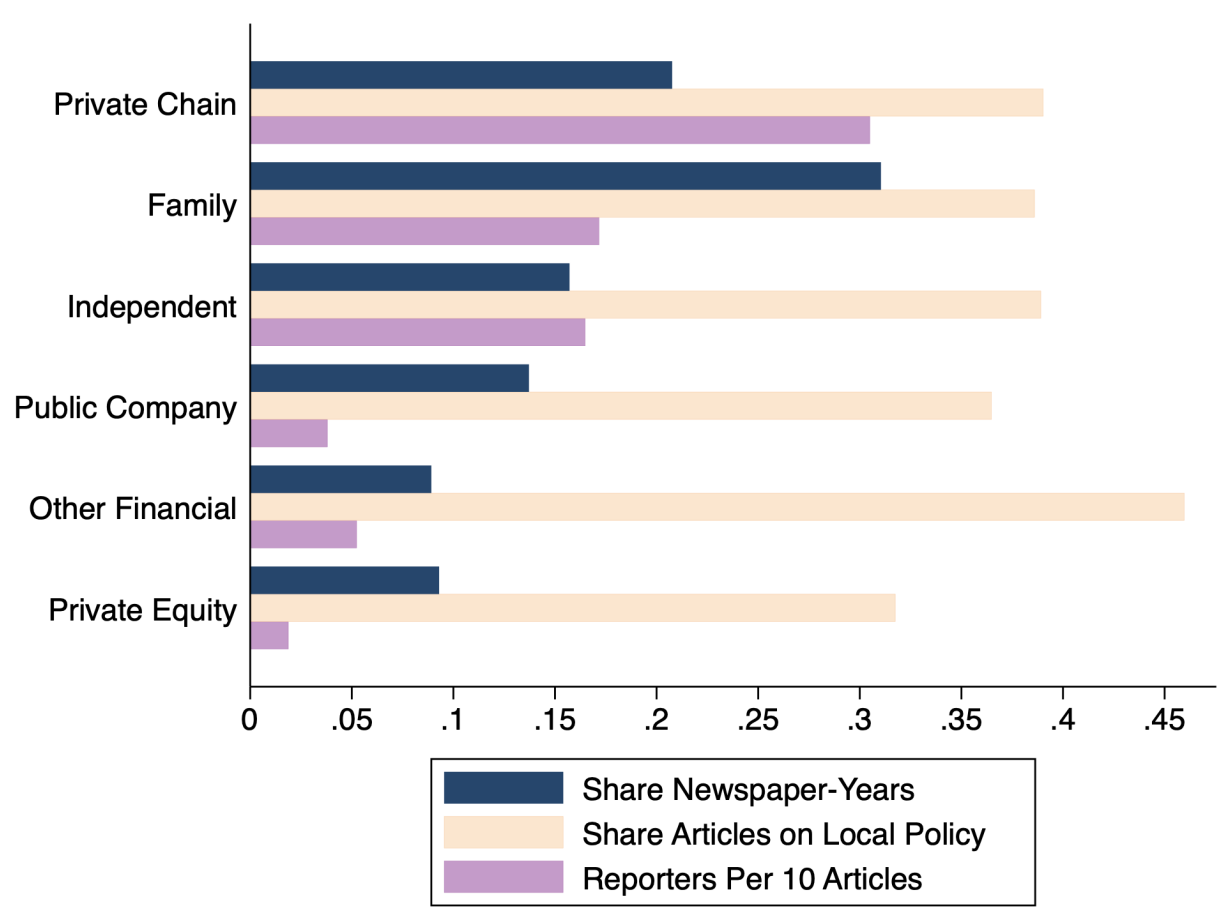

B. Comparison of Key Statistics Across Ownership Types

Note:This figure shows ownership dynamics and key relative characteristics in our sample of daily newspapers. We include the major ownership types. Ownership types are mutually exclusive. If a newspaper is identified as family-owned, that status takes precedence vis-a-vis chain or independent status. 


\section{Figure 3: Difference-in-differences Event Studies on Effects of Private Equity Ownership}

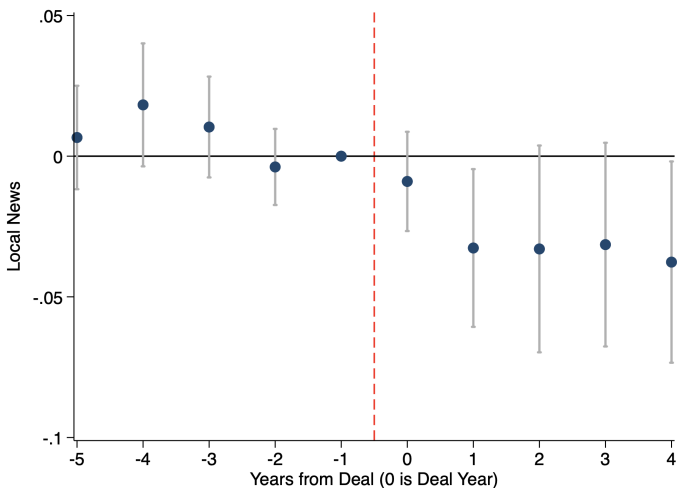

A. Local Government Content Share

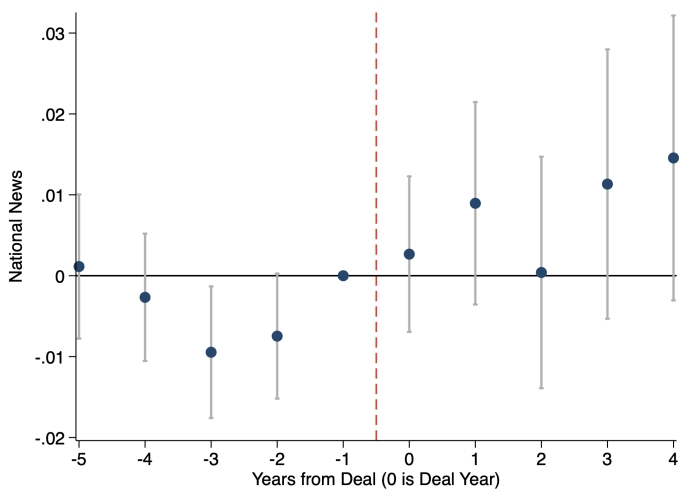

C. National Politics Content Share

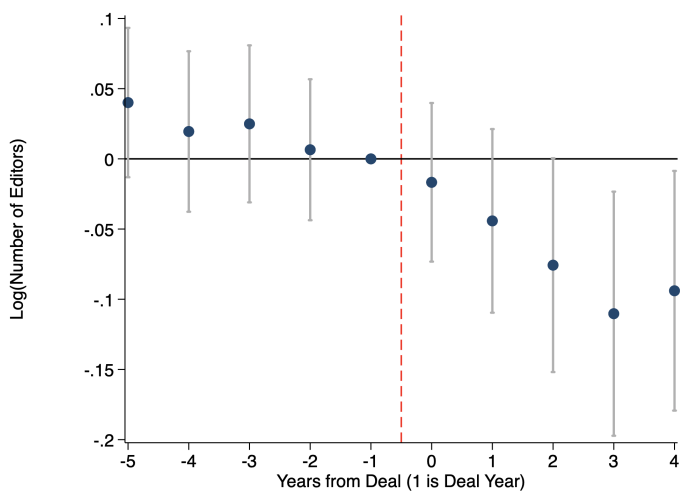

E. Editors

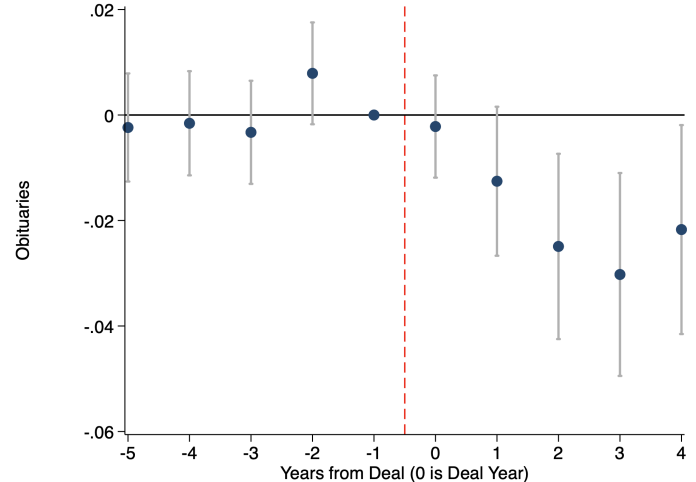

B. Obituary Content Share

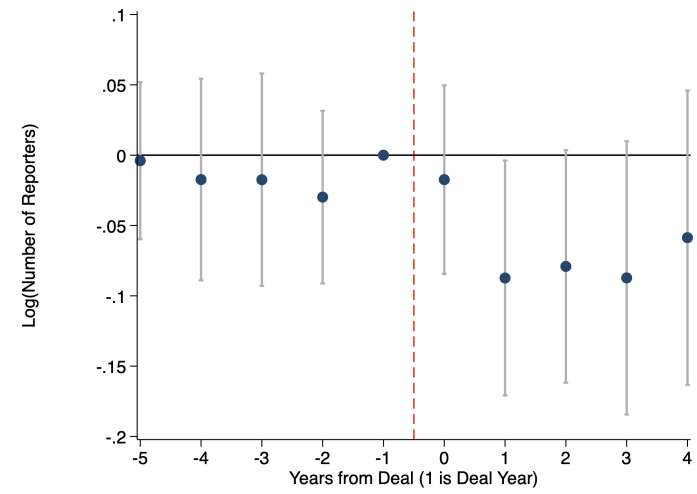

D. Reporters

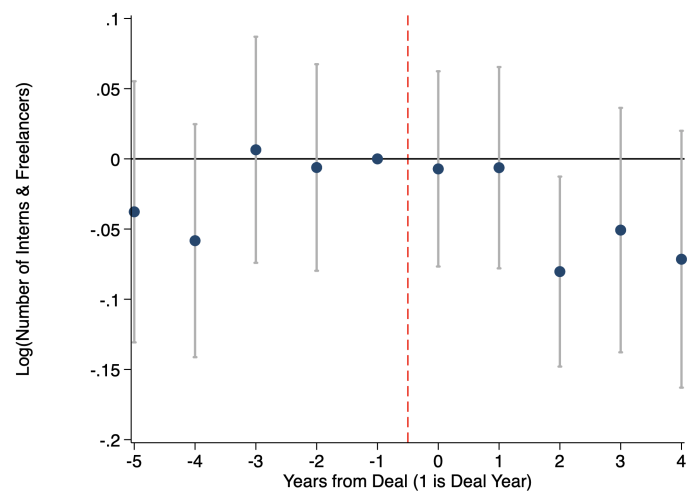

F. Interns/Freelancers

Note: This figure presents the difference-in-differences event studies around the time a newspaper experiences a private equity buyout. We leave out the year before the deal $(-1)$. The regression includes year and newspaper fixed effects, as well as dummies for each year around the buyout (34 total dummies). Only the coefficients for the years immediately around the buyout are shown in the graph. Article content outcomes are in Panels A-C. Local policy articles (Panel A) include any of the following words: city council, city hall, mayor, state senate, state legislature, zoning, planning board, board of education, school board, school district, municipal, sheriff, police, local policy. Obituaries (Panel B) include any of the following words: died, finally at peace, or passed away. National politics articles (Panel C) include any of the following words: Bush, Congress, Obama, Trump, White House, Democrat, Republican. Employees by occupation are in Panels D-F. In each case, the dependent variable is the log number of employees in a certain occupational category. $95 \%$ confidence intervals shown. 
Table 1: Summary Statistics

\begin{tabular}{|c|c|c|c|c|c|c|c|c|}
\hline & \multicolumn{2}{|r|}{ All } & \multicolumn{2}{|c|}{ Non-Private Equity } & \multicolumn{2}{|c|}{ Pre-Private Equity } & \multicolumn{2}{|c|}{ Post-Private Equity } \\
\hline & $\mathrm{N}$ & Mean (SD) & $\mathrm{N}$ & Mean (SD) & $\mathrm{N}$ & Mean (SD) & $\mathrm{N}$ & Mean (SD) \\
\hline \multicolumn{9}{|l|}{ Share Articles: } \\
\hline Local Government & 11449 & $0.33(0.17)$ & 7681 & $0.34(0.18)$ & 1331 & $0.35(0.19)$ & 2220 & $0.28(0.13)$ \\
\hline Obituaries & 11449 & $0.14(0.10)$ & 7681 & $0.14(0.10)$ & 1331 & $0.15(0.10)$ & 2220 & $0.13(0.09)$ \\
\hline National Politics & 11449 & $0.16(0.17)$ & 7681 & $0.16(0.17)$ & 1331 & $0.15(0.15)$ & 2220 & $0.16(0.19)$ \\
\hline AP Wire & 11449 & $0.05(0.08)$ & 7681 & $0.05(0.09)$ & 1331 & $0.06(0.09)$ & 2220 & $0.03(0.05)$ \\
\hline Local Policy - Schools & 11449 & $0.05(0.03)$ & 7681 & $0.05(0.03)$ & 1331 & $0.05(0.03)$ & 2220 & $0.05(0.03)$ \\
\hline China/Russia & 11449 & $0.02(0.01)$ & 7681 & $0.02(0.01)$ & 1331 & $0.01(0.01)$ & 2220 & $0.02(0.02)$ \\
\hline \multicolumn{9}{|l|}{ Number Articles: } \\
\hline All & 11449 & 13999 ( 14026$)$ & 7681 & 14924 ( 14669$)$ & 1331 & 17462 ( 15029) & 2220 & 8894 ( 9217) \\
\hline Local Government & 11449 & 4346 ( 4678) & 7681 & 4658 ( 4799) & 1331 & $5778(5381)$ & 2220 & $2433(2880)$ \\
\hline Obituaries & 11449 & $1831(2210)$ & 7681 & 1947 ( 2259) & 1331 & 2425 ( 2507) & 2220 & $1120(1625)$ \\
\hline National Politics & 11449 & 2273 ( 2911) & 7681 & 2484 ( 3177$)$ & 1331 & $2500(2521)$ & 2220 & 1447 ( 1907) \\
\hline AP Wire & 11449 & 1072 ( 2432) & 7681 & 1185 ( 2568$)$ & 1331 & 1547 ( 2958) & 2220 & $376(883)$ \\
\hline Local Policy - Schools & 11449 & $580(592)$ & 7681 & $622(629)$ & 1331 & $718(573)$ & 2220 & 356 ( 369$)$ \\
\hline China/Russia & 11449 & 277 ( 385$)$ & 7681 & $305(416)$ & 1331 & 309 ( 378$)$ & 2220 & 165 ( 234) \\
\hline Reporters & 13122 & $5.46(8.74)$ & 10819 & $5.60(8.98)$ & 885 & $6.36(8.40)$ & 1369 & $3.77(6.70)$ \\
\hline Editors & 13122 & $6.69(10.98)$ & 10819 & $6.72(11.12)$ & 885 & $9.27(11.96)$ & 1369 & $4.70(8.55)$ \\
\hline Interns and Freelancers & 13122 & $1.57(3.06)$ & 10819 & $1.58(3.10)$ & 885 & $1.77(2.88)$ & 1369 & $1.31(2.81)$ \\
\hline Employees & 13122 & $36.47(60.31)$ & 10819 & 37.14 ( 61.63$)$ & 885 & $45.11(60.83)$ & 1369 & $25.58(47.10)$ \\
\hline Circulation & 22792 & 22037 ( 28021) & 17066 & $20933(27454)$ & 3005 & 35667 ( 32547$)$ & 2721 & $13910(20037)$ \\
\hline Digital Circulation & 3419 & $32392(217200)$ & 2333 & 37412 ( 258649) & 643 & $14558(33155)$ & 443 & 31841 ( 98274) \\
\hline Advertising (Max open inch rate) & 22192 & $46.51(86.21)$ & 16745 & $43.93(86.90)$ & 2858 & 72.47 ( 89.82$)$ & 2589 & $34.48(70.94)$ \\
\hline Closed & 27474 & $0.01(0.10)$ & 20697 & $0.01(0.11)$ & 3511 & $0(0.02)$ & 3050 & $0.01(0.10)$ \\
\hline Shut Down & 27933 & $0.003(0.06)$ & 21060 & $0.004(0.06)$ & 3512 & $0(0)$ & 3053 & $0.003(0.05)$ \\
\hline Merged \& Changed Name & 27856 & $0.003(0.05)$ & 21013 & $0.003(0.06)$ & 3511 & $0(0.02)$ & 3052 & $0.004(0.07)$ \\
\hline Changed to Weekly & 27781 & $0.005(0.07)$ & 20918 & $0.01(0.08)$ & 3512 & $0(0)$ & 3051 & $0.004(0.06)$ \\
\hline \multicolumn{9}{|l|}{ County-Level Elections: } \\
\hline Council Votes (Thou) & 2119 & $32.35(36.81)$ & 1714 & $34.12(37.70)$ & 191 & 32.66 ( 32.70$)$ & 214 & $17.93(29.17)$ \\
\hline Council Turnout & 2117 & $8.72(12.19)$ & 1712 & $8.86(12.06)$ & 191 & $12.04(16.34)$ & 214 & $4.66(6.69)$ \\
\hline Mayor Votes (Thou) & 1960 & $26.11(58.65)$ & 1663 & $25.76(58.35)$ & 127 & $36.44(68.31)$ & 170 & $21.85(52.96)$ \\
\hline Mayor Turnout & 1960 & $4.64(5.53)$ & 1663 & $4.72(5.54)$ & 127 & $5.44(6.78)$ & 170 & $3.24(4.05)$ \\
\hline Sheriff Votes (Thou) & 487 & $47.55(57.14)$ & 389 & $47.23(56.98)$ & 47 & $62.82(67.25)$ & 51 & $35.89(44.95)$ \\
\hline Sheriff Turnout & 487 & $30.01(7.43)$ & 389 & 30.17 ( 7.54) & 47 & $30.13(7.34)$ & 51 & $28.62(6.54)$ \\
\hline \multicolumn{9}{|l|}{ Congressional Elections: } \\
\hline Log total votes & 2219 & $12.31(0.32)$ & 785 & $12.29(0.33)$ & 236 & $12.24(0.32)$ & 1198 & $12.34(0.31)$ \\
\hline Turnout & 2219 & $0.20(0.11)$ & 785 & $0.18(0.10)$ & 236 & $0.19(0.11)$ & 1198 & $0.21(0.11)$ \\
\hline Dem vote share & 2219 & 45.59 ( 19.99) & 785 & $47.84(21.91)$ & 236 & $45.27(19.29)$ & 1198 & 44.18 ( 18.64$)$ \\
\hline Incumbent reelected & 2219 & $0.99(0.08)$ & 785 & $0.99(0.09)$ & 236 & $1.00(0.07)$ & 1198 & $0.99(0.08)$ \\
\hline Uncontested election & 2219 & $0.35(0.48)$ & 785 & $0.40(0.49)$ & 236 & $0.22(0.42)$ & 1198 & $0.33(0.47)$ \\
\hline \# bills & 2219 & $6.70(5.05)$ & 785 & $7.12(5.43)$ & 236 & $5.85(4.23)$ & 1198 & $6.59(4.91)$ \\
\hline \multicolumn{9}{|l|}{ State Legislative Elections: } \\
\hline Log Num Votes & 39016 & $9.76(0.96)$ & 31709 & $9.74(0.97)$ & 1391 & $10.02(0.98)$ & 5916 & $9.77(0.89)$ \\
\hline One candidate & 39016 & $0.32(0.47)$ & 31709 & $0.32(0.47)$ & 1391 & $0.27(0.45)$ & 5916 & $0.36(0.48)$ \\
\hline Close election & 39016 & $0.07(0.25)$ & 31709 & $0.07(0.25)$ & 1391 & $0.07(0.26)$ & 5916 & $0.06(0.24)$ \\
\hline Winning $\%$ edge & 38558 & $0.52(0.38)$ & 31322 & $0.52(0.37)$ & 1388 & $0.47(0.36)$ & 5848 & $0.54(0.38)$ \\
\hline
\end{tabular}

Note: This table shows summary statistics about our data at the newspaper-year level. Variables are defined in Section 2 . The left-most three columns include the whole sample, the middle three columns include newspaper-years under private equity ownership, and the right-most three columns include newspaper-years not under private equity ownership (including targets pre-buyout). The samples differ based on matching to the source of characteristic data, which is content from NewsLibrary (first two blocks of variables), employment outcomes (third block), circulation and advertising where populated in E\&P (fourth block), closure (fifth block), and political variables (sixth block). 
Table 2: Private Equity Ownership and Local Elections

\begin{tabular}{|c|c|c|c|c|c|c|}
\hline \multirow{3}{*}{$\begin{array}{l}\text { Election Type: } \\
\text { Dependent Variable: }\end{array}$} & \multicolumn{5}{|c|}{ Panel A: Local Election Participation } & \\
\hline & \multicolumn{3}{|c|}{ County Council } & \multicolumn{3}{|c|}{ Mayor } \\
\hline & Total Votes & $\begin{array}{c}\text { Log Total } \\
\text { Votes }\end{array}$ & Turnout (\%) & Total Votes & $\begin{array}{l}\text { Log Total } \\
\text { Votes }\end{array}$ & Turnout $(\%)$ \\
\hline & (1) & (2) & (3) & (4) & (5) & (6) \\
\hline Post deal X PE & $\begin{array}{l}-3.005^{*} \\
(1.730)\end{array}$ & $\begin{array}{l}-0.133^{*} \\
(0.079)\end{array}$ & $\begin{array}{c}-0.821^{* *} \\
(0.407)\end{array}$ & $\begin{array}{l}-1.545 \\
(4.094)\end{array}$ & $\begin{array}{l}-0.175^{*} \\
(0.098)\end{array}$ & $\begin{array}{l}-0.198 \\
(0.293)\end{array}$ \\
\hline Observations & 2124 & 2124 & 2122 & 1960 & 1960 & 1960 \\
\hline$R^{2}$ & 0.299 & 0.196 & 0.076 & 0.155 & 0.083 & 0.034 \\
\hline Year FE & Yes & Yes & Yes & Yes & Yes & Yes \\
\hline Newspaper FE & Yes & Yes & Yes & Yes & Yes & Yes \\
\hline Outcome Mean & 32.283 & 9.492 & 8.745 & 26.111 & 8.848 & 4.637 \\
\hline
\end{tabular}

Panel B: Survey-Based Measures of News Interest and Government Knowledge

\begin{tabular}{|c|c|c|c|c|c|}
\hline \multirow[b]{2}{*}{ Dependent Variable: } & \multirow[b]{2}{*}{$\begin{array}{c}\text { High News } \\
\text { Interest }\end{array}$} & \multicolumn{4}{|c|}{ No Opinion Of } \\
\hline & & House Rep & Senator & Governor & President \\
\hline & (1) & (2) & (3) & (4) & (5) \\
\hline Post deal X PE & $\begin{array}{l}-0.013 \\
(0.009)\end{array}$ & $\begin{array}{c}0.020^{* * *} \\
(0.008)\end{array}$ & $\begin{array}{c}0.004 \\
(0.008)\end{array}$ & $\begin{array}{c}0.006 \\
(0.006)\end{array}$ & $\begin{array}{c}0.002 \\
(0.003)\end{array}$ \\
\hline Observations & 22170 & 22170 & 22170 & 22170 & 22170 \\
\hline Year FE & Yes & Yes & Yes & Yes & Yes \\
\hline County FE & Yes & Yes & Yes & Yes & Yes \\
\hline Outcome Mean & 0.500 & 0.183 & 0.182 & 0.102 & 0.030 \\
\hline
\end{tabular}

Note: This table shows the relationship between private equity ownership and political outcomes. In Panel A, we consider two types of local elections: county legislature (columns 1-3) and mayoral (columns 4-6) elections. Total votes are in thousands. Turnout is defined as total votes divided by the local population (based on U.S. Census data). The specification is the same as in previous tables. In Panel B, we examine survey responses from the Cooperative Congressional Election Study (CCES) across the 2006-2019 waves. Column 1 asks individuals if they have a strong ideology; column 2 asks about high news interest; and columns 3-6 examine response rates of individuals who have "No Opinion" about a range of elected officials from their district. The key independent variable is whether newspapers serving that county-year are owned by private equity. In this panel, standard errors are clustered at the county level. *** denotes $\mathrm{p}$-value $<.01$, ** denotes $\mathrm{p}$-value $<.05$, and $*$ denotes p-value $<.1$. 


\section{Table 3: Private Equity Ownership and Supplementary State Elections}

Panel A: State Legislative Elections

Dependent Variable: Log \# votes One Candidate Close election Log win. \% diff

\begin{tabular}{lcccc} 
& $(1)$ & $(2)$ & $(3)$ & $(4)$ \\
\hline Has PE paper & $-0.016^{* * *}$ & 0.017 & $-0.017^{*}$ & 0.054 \\
& $(0.006)$ & $(0.017)$ & $(0.010)$ & $(0.036)$ \\
\hline Observations & 39016 & 39016 & 39016 & 38558 \\
$R^{2}$ & 0.666 & 0.004 & 0.001 & 0.005 \\
State District FE & Yes & Yes & Yes & Yes \\
Year FE & Yes & Yes & Yes & Yes \\
Controls & Yes & Yes & Yes & Yes \\
Outcome Mean & 9.757 & 0.353 & 0.063 & -1.094 \\
\hline
\end{tabular}

Panel B: Congressional Elections and Members

\begin{tabular}{lcccccc} 
Dependent Variable: & $\begin{array}{c}\text { Total } \\
\text { Votes }\end{array}$ & Turnout & $\begin{array}{c}\text { Democratic } \\
\text { Vote Share }\end{array}$ & $\begin{array}{c}\text { Uncontested } \\
\text { Election }\end{array}$ & $\begin{array}{c}\text { Incumbent } \\
\text { Reelected }\end{array}$ & \# Bills \\
& $(1)$ & $(2)$ & $(3)$ & $(4)$ & $(5)$ & $(6)$ \\
\hline Post deal X PE & $-0.017^{*}$ & $-0.004^{* *}$ & $-2.097^{*}$ & 0.024 & $0.108^{* *}$ & $-1.102^{*}$ \\
& $(0.009)$ & $(0.002)$ & $(1.231)$ & $(0.039)$ & $(0.045)$ & $(0.571)$ \\
\hline Observations & 2119 & 2119 & 2119 & 2119 & 1893 & 1893 \\
$R^{2}$ & 0.923 & 0.967 & 0.781 & 0.558 & 0.320 & 0.549 \\
Cong. District FE & Yes & Yes & Yes & Yes & Yes & Yes \\
Congress FE & Yes & Yes & Yes & Yes & Yes & Yes \\
Controls & Yes & Yes & Yes & Yes & Yes & Yes \\
Outcome Mean & 12.310 & 0.200 & 45.332 & 0.342 & 0.843 & 11.082 \\
\hline
\end{tabular}

Note: This table shows the relationship between private equity ownership and political outcomes based on district-level elections. In Panel A, we consider outcomes in State legislature elections at the state legislative district-year level. Newspapers are matched to districts at the larger DMA level. We consider four dependent variables. First, the log number of votes. Second, whether there is only one candidate running in an election. Third, an indicator for a close election, defined as the difference between the percent of the vote going to the winner and to the runner up is less than $5 \%$. Fourth, the log win percent, which is the $\log$ of the difference between the percent of the vote going to the winner and to the runner up. We control for the estimated log population of the district and the number of seats up for election. In Panel B, we consider outcomes in Congressional elections, at the Congressional district level (which is much larger than state legislative districts), but available only for Congressional election years. Observations are at the district-Congress level and thus we include Congress fixed effects. The dependent variables are as follows. First, a $(\log )$ measure of the total number of votes. Second, turnout which is measured by dividing the total number of votes by the voter eligible population in the Congressional District taken from the American Community Survey. Third, the share of the two-party vote which goes to Democrats. Fourth, an indicator for whether the election was uncontested. Fifth, a dummy variable for whether the incumbent was re-elected. And sixth, the number of bills proposed by the sitting member of Congress for the district, winsorized at the 99th percentile. We control for the estimated log population of the district. In both panels, standard errors are clustered at the district level. *** denotes p-value $<.01$, ** denotes p-value $<.05$, and $*$ denotes p-value $<.1$. 
Table 4: Private Equity Ownership and Article Content

\begin{tabular}{lcccc}
\hline \multicolumn{5}{c}{ Panel A: Share of Articles } \\
Dependent Variable: & Local Government & Obituaries & National Politics & AP Wire \\
& & & & \\
& $(1)$ & $(2)$ & $(3)$ & $(4)$ \\
\hline Post deal X PE & $-0.036^{* *}$ & $-0.013^{*}$ & $0.013^{* *}$ & -0.008 \\
& $(0.014)$ & $(0.007)$ & $(0.007)$ & $(0.007)$ \\
\hline Observations & 10952 & 10952 & 10952 & 10952 \\
Year FE & Yes & Yes & Yes & Yes \\
Newspaper FE & Yes & Yes & Yes & Yes \\
Outcome Mean & 0.332 & 0.139 & 0.157 & 0.050 \\
\hline
\end{tabular}

Panel B: Log Number of Articles

\begin{tabular}{lccccc} 
Dependent Variable: & Local Government & Obituaries & National Politics & AP Wire & Total \\
& & & & & \\
& $(1)$ & $(2)$ & $(3)$ & $(4)$ & $(5)$ \\
\hline Post deal X PE & $-0.256^{* * *}$ & $-0.345^{* * *}$ & -0.122 & $-0.240^{*}$ & $-0.183^{* * *}$ \\
& $(0.054)$ & $(0.081)$ & $(0.081)$ & $(0.129)$ & $(0.054)$ \\
\hline Observations & 10952 & 10952 & 10952 & 10952 & 10952 \\
Year FE & Yes & Yes & Yes & Yes & Yes \\
Newspaper FE & Yes & Yes & Yes & Yes & Yes \\
Outcome Mean & 7.895 & 6.930 & 6.972 & 5.274 & 9.122 \\
\hline
\end{tabular}

Note: This table shows the effect of private equity buyouts on the share (Panel A) and log number (Panel B) of a newspaper's total articles that fall into a particular topic area (a single article can cover multiple topics). Local policy "government" articles (column 1) include any of the following words: city council, city hall, mayor, state senate, state legislature, zoning, and planning board. Obituaries (column 2) are articles including any of the following words: died, finally at peace, or passed away. National politics articles (column 3) include any of the following words: Bush, Congress, Obama, Trump, White House, democrat, or republican. AP Wire (column 4) refers to syndicated articles from the Associated Press. Total articles are in Column B, column 5. Standard errors are clustered by newspaper. $* * *$ denotes p-value $<.01$, ** denotes p-value $<.05$, and $*$ denotes $\mathrm{p}$-value $<.1$. 


\section{Table 5: Private Equity Ownership and Employees}

\begin{tabular}{lcccc}
\hline Dependent Variable: & Reporters & Editors & $\begin{array}{c}\text { Interns \& } \\
\text { Freelancers }\end{array}$ & Employees \\
& $(1)$ & $(2)$ & $(3)$ & $(4)$ \\
\hline Post deal X PE & $-0.076^{*}$ & $-0.093^{* * *}$ & -0.004 & $-0.074^{* *}$ \\
& $(0.040)$ & $(0.035)$ & $(0.041)$ & $(0.038)$ \\
\hline Observations & 12641 & 12641 & 12641 & 12641 \\
$R^{2}$ & 0.092 & 0.045 & 0.130 & 0.181 \\
Year FE & Yes & Yes & Yes & Yes \\
Newspaper FE & Yes & Yes & Yes & Yes \\
Outcome Mean & 1.188 & 1.717 & 0.518 & 2.531 \\
\hline
\end{tabular}

Note: This table shows the effect of private equity buyouts on the logged number of employees. The sample is restricted to newspaper-years with at least one reporter. Employee data are from LinkedIn, and occupations are derived from job titles. Standard errors are clustered by newspaper. $* * *$ denotes $\mathrm{p}$-value $<.01, * *$ denotes $\mathrm{p}$-value $<.05$, and $*$ denotes p-value $<.1$. 
Table 6: Private Equity Ownership and Operations

\begin{tabular}{|c|c|c|c|c|c|c|}
\hline \multirow{3}{*}{ Dependent Variable: } & \multicolumn{4}{|c|}{ Panel A: Circulation \& Advertising } & \multirow{2}{*}{\multicolumn{2}{|c|}{ Advertising Rate }} \\
\hline & \multicolumn{4}{|c|}{ Circulation } & & \\
\hline & $\begin{array}{c}\text { No Stale } \\
\text { (1) }\end{array}$ & $\begin{array}{l}\text { All } \\
(2)\end{array}$ & $\begin{array}{l}\text { Digital } \\
\text { (3) }\end{array}$ & $\begin{array}{l}\text { All } \\
(4)\end{array}$ & $\begin{array}{c}\text { No Stale } \\
\text { (5) }\end{array}$ & $\begin{array}{l}\text { All } \\
(6)\end{array}$ \\
\hline Post deal X PE & $\begin{array}{c}-0.083^{* * *} \\
(0.016)\end{array}$ & $\begin{array}{c}-0.117^{* * *} \\
(0.019)\end{array}$ & $\begin{array}{c}0.364^{*} \\
(0.208)\end{array}$ & $\begin{array}{c}-0.073^{* * *} \\
(0.018)\end{array}$ & $\begin{array}{l}-0.034 \\
(0.031)\end{array}$ & $\begin{array}{l}-0.042^{*} \\
(0.024)\end{array}$ \\
\hline Observations & 15037 & 22790 & 3287 & 3416 & 10549 & 22192 \\
\hline$R^{2}$ & 0.606 & 0.433 & 0.102 & 0.755 & 0.093 & 0.087 \\
\hline Year FE & Yes & Yes & Yes & Yes & Yes & Yes \\
\hline Newspaper FE & Yes & Yes & Yes & Yes & Yes & Yes \\
\hline Outcome Mean & 9.775 & 9.427 & 5.030 & 10.100 & 3.200 & 3.183 \\
\hline
\end{tabular}

Panel B: Closure or Change of Status

\begin{tabular}{lcccc} 
Dependent Variable: & $\begin{array}{c}\text { Any Closure } \\
(1)\end{array}$ & $\begin{array}{c}\text { Shut Down } \\
(2)\end{array}$ & $\begin{array}{c}\text { Merged \& New Name } \\
(3)\end{array}$ & $\begin{array}{c}\text { Became Weekly } \\
(4)\end{array}$ \\
\hline Post deal X PE & $-0.004^{* *}$ & $-0.002^{* *}$ & 0.001 & $-0.003^{* *}$ \\
& $(0.002)$ & $(0.001)$ & $(0.001)$ & $(0.001)$ \\
\hline Observations & 26720 & 26736 & 26730 & 26730 \\
$R^{2}$ & 0.024 & 0.008 & 0.008 & 0.016 \\
Year FE & Yes & Yes & Yes & Yes \\
State FE & Yes & Yes & Yes & Yes \\
Outcome Mean & 0.011 & 0.004 & 0.003 & 0.005 \\
\hline
\end{tabular}

Note: Panel A of this table shows the effect of private equity buyouts on log print circulation (number of subscribers) and log advertising rate (dollars per open inch, which is the rate charged to a new advertiser who does not have an existing discount per square inch). In column 1 and 3, the sample is restricted to newspaper-years in which circulation or advertising rates change from year to year, in case the absence of change represents stale data. Panel B of this table shows the effect of private equity buyouts on three newspaper outcomes: closure (columns 1-2), merger and change of name (columns 3-4), and a switch from being a daily newspaper to a weekly (column 5-6). Note only dailies, not weeklies, comprise the main sample. We show models both with and without newspaper fixed effects as these events can happen only once in a newspaper's life. Standard errors are clustered by newspaper. $* * *$ denotes $\mathrm{p}$-value $<.01$, ** denotes $\mathrm{p}$-value $<.05$, and $*$ denotes $\mathrm{p}$-value $<.1$. 


\section{Table 7: Local Preferences via Google Trends Robustness Test}

\begin{tabular}{lccccc}
\hline \multirow{2}{*}{ Dependent Variable: } & \multicolumn{2}{c}{ Local Government } & & \multicolumn{2}{c}{ National Politics } \\
\cline { 2 - 3 } \cline { 6 - 6 } & Mean & Sum & & Mean & Sum \\
& & & & \\
& $(1)$ & $(2)$ & & $(3)$ & $(4)$ \\
\hline Post deal X PE & $0.105^{* * *}$ & $0.013^{* * *}$ & & 0.024 & 0.004 \\
& $(0.039)$ & $(0.005)$ & & $(0.032)$ & $(0.005)$ \\
\hline Observations & 8375 & 8375 & & 8375 & 8375 \\
Year FE & Yes & Yes & & Yes & Yes \\
Newspaper FE & Yes & Yes & & Yes & Yes \\
Outcome Mean & 4.064 & 0.479 & & 2.858 & 0.427 \\
\hline
\end{tabular}

Note: The table reports the effects of private equity buyouts on local Google search trends for the local and national keywords. In columns 1 and 3, the dependent variables are constructed as means of the keyword search intensity across all the keywords in our local and national government measures from Table 4 columns 1 and 3. In columns 2 and 4 , the dependent variables are constructed the same way except as sums. All specifications are otherwise identical to those in Table 4 . The sample is smaller because the Google trends data are only available starting in 2006. Google search trend data is at the DMA level. *** denotes $\mathrm{p}$-value $<.01, * *$ denotes $\mathrm{p}$-value $<.05$, and $*$ denotes $\mathrm{p}$-value $<.1$. 
Table 8: Private Equity Relative to Other Types of Ownership

\begin{tabular}{|c|c|c|c|c|}
\hline \multirow{3}{*}{$\begin{array}{l}\text { Election Type: } \\
\text { Dependent Variable: }\end{array}$} & \multicolumn{3}{|c|}{ Panel A: Local Election Participation } & \\
\hline & \multicolumn{2}{|c|}{ County Council } & \multicolumn{2}{|c|}{ Mayor } \\
\hline & $\begin{array}{c}\text { Turnout (\%) } \\
\text { (1) }\end{array}$ & $\begin{array}{c}\text { Turnout (\%) } \\
\text { (2) }\end{array}$ & $\begin{array}{c}\text { Turnout (\%) } \\
\text { (3) }\end{array}$ & $\begin{array}{c}\text { Turnout (\%) } \\
\text { (4) }\end{array}$ \\
\hline Independent & $\begin{array}{l}4.447^{* * *} \\
(1.428)\end{array}$ & $\begin{array}{l}-0.207 \\
(0.869)\end{array}$ & $\begin{array}{c}0.579 \\
(0.658)\end{array}$ & $\begin{array}{l}-0.210 \\
(0.415)\end{array}$ \\
\hline Family & $\begin{array}{l}5.918^{* * *} \\
(1.291)\end{array}$ & $\begin{array}{c}0.106 \\
(0.565)\end{array}$ & $\begin{array}{l}2.939^{* * * *} \\
(0.701)\end{array}$ & $\begin{array}{c}0.129 \\
(0.330)\end{array}$ \\
\hline Private Chain & $\begin{array}{l}3.714^{* * * *} \\
(1.055)\end{array}$ & $\begin{array}{c}0.277 \\
(0.401)\end{array}$ & $\begin{array}{c}0.259 \\
(0.619)\end{array}$ & $\begin{array}{c}0.199 \\
(0.295)\end{array}$ \\
\hline Public Co. & $\begin{array}{l}4.699^{* * *} \\
(1.388)\end{array}$ & $\begin{array}{c}0.627 \\
(0.648)\end{array}$ & $\begin{array}{l}1.903^{* *} \\
(0.820)\end{array}$ & $\begin{array}{c}0.421 \\
(0.344)\end{array}$ \\
\hline Other Fin. Firm & $\begin{array}{l}4.196^{* *} \\
(1.764)\end{array}$ & $\begin{array}{l}1.476^{*} \\
(0.808)\end{array}$ & $\begin{array}{c}0.808 \\
(0.665)\end{array}$ & $\begin{array}{l}0.671^{*} \\
(0.373)\end{array}$ \\
\hline Observations & 2145 & 2123 & 1988 & 1963 \\
\hline$R^{2}$ & 0.094 & 0.823 & 0.107 & 0.656 \\
\hline Year FE & Yes & Yes & Yes & Yes \\
\hline Newspaper FE & No & Yes & No & Yes \\
\hline Outcome Mean & 8.770 & 8.735 & 4.679 & 4.677 \\
\hline
\end{tabular}

Panel B: Article Content by Ownership Type with Private Equity as Base Group

\begin{tabular}{|c|c|c|c|c|c|c|c|c|}
\hline \multirow[t]{3}{*}{ Dependent Variable: } & \multicolumn{4}{|c|}{ Share of Articles on } & \multicolumn{4}{|c|}{ Number of Articles on } \\
\hline & \multicolumn{2}{|c|}{ Local Government } & \multicolumn{2}{|c|}{ National Politics } & \multicolumn{2}{|c|}{ Local Government } & \multicolumn{2}{|c|}{ National Politics } \\
\hline & (1) & (2) & (3) & (4) & $(5)$ & (6) & (7) & (8) \\
\hline \multirow[t]{2}{*}{ Independent } & $0.072^{* * *}$ & $0.042^{* *}$ & 0.003 & $-0.014^{* *}$ & $0.604^{* * *}$ & $0.121^{*}$ & $0.562^{* * *}$ & -0.064 \\
\hline & $(0.017)$ & $(0.018)$ & $(0.018)$ & $(0.006)$ & $(0.084)$ & $(0.063)$ & $(0.126)$ & $(0.089)$ \\
\hline \multirow[t]{2}{*}{ Family } & $0.063^{* * *}$ & $0.030^{* *}$ & -0.011 & $-0.010^{*}$ & $0.755^{* * *}$ & $0.144^{* * *}$ & $0.659^{* * *}$ & 0.008 \\
\hline & $(0.011)$ & $(0.013)$ & $(0.015)$ & $(0.006)$ & $(0.084)$ & $(0.051)$ & $(0.111)$ & $(0.074)$ \\
\hline \multirow[t]{2}{*}{ Private Chain } & $0.057^{* * *}$ & 0.023 & 0.024 & -0.006 & $0.644^{* * *}$ & $0.110^{* *}$ & $0.729^{* * *}$ & 0.026 \\
\hline & $(0.013)$ & $(0.014)$ & $(0.018)$ & $(0.006)$ & $(0.084)$ & $(0.052)$ & $(0.108)$ & $(0.074)$ \\
\hline \multirow[t]{2}{*}{ Public Co. } & $0.045^{* * *}$ & 0.018 & 0.005 & -0.008 & $0.936^{* * *}$ & 0.105 & $0.970^{* * *}$ & -0.012 \\
\hline & $(0.014)$ & $(0.019)$ & $(0.022)$ & $(0.007)$ & $(0.094)$ & $(0.070)$ & $(0.130)$ & $(0.083)$ \\
\hline \multirow[t]{2}{*}{ Other Fin. Firm } & $0.153^{* * *}$ & $0.056^{* * *}$ & 0.018 & 0.005 & $0.560^{* * *}$ & 0.046 & $0.336^{* * *}$ & -0.070 \\
\hline & $(0.015)$ & $(0.020)$ & $(0.023)$ & $(0.009)$ & $(0.089)$ & $(0.066)$ & $(0.126)$ & $(0.098)$ \\
\hline Observations & 10892 & 10886 & 10892 & 10886 & 10892 & 10886 & 10892 & 10886 \\
\hline Year FE & Yes & Yes & Yes & Yes & Yes & Yes & Yes & Yes \\
\hline Newspaper FE & No & Yes & No & Yes & No & Yes & No & Yes \\
\hline Outcome Mean & 0.380 & 0.380 & 0.157 & 0.157 & 8.045 & 8.045 & 6.972 & 6.972 \\
\hline
\end{tabular}

Note: This table shows the relationship between major newspaper ownership types and article content in Panel A, and political participation in Panel B. Private equity ownership represents the base group. For each outcome, the first column does not include newspaper fixed effects, so the coefficients show the average for each ownership type in the whole sample. The second column includes newspaper fixed effects, which means that the coefficient is identified only from newspapers that change to or from the ownership type. The dependent variables in Panel A are voter turnout in county legislative council elections (columns 1-2) and mayoral elections (columns 3-4). Turnout is defined as total votes divided by the local population (based on U.S. Census data). The dependent variables in Panel B are the share (columns 1-4) and number (columns 5-8) of articles with a particular type of content. Standard errors are clustered by newspaper. $* * *$ denotes p-value $<.01$, ** denotes p-value $<.05$, and $*$ denotes p-value $<.1$. 
Panel C: Employees by Ownership Type with Private Equity as Base Group Dependent Variable: Reporters Interns \&

\begin{tabular}{|c|c|c|c|c|c|c|}
\hline \multirow[t]{2}{*}{ Dependent Variable: } & \multicolumn{2}{|c|}{ Reporters } & \multicolumn{2}{|c|}{ Editors } & \multicolumn{2}{|c|}{$\begin{array}{l}\text { Interns \& } \\
\text { Freelancers }\end{array}$} \\
\hline & $(1)$ & $(2)$ & (3) & (4) & $(5)$ & (6) \\
\hline \multirow[t]{2}{*}{ Independent } & 0.168 & $0.098^{* *}$ & 0.059 & $0.083^{*}$ & 0.092 & $0.080^{*}$ \\
\hline & $(0.120)$ & $(0.046)$ & $(0.127)$ & $(0.043)$ & $(0.080)$ & $(0.046)$ \\
\hline \multirow[t]{2}{*}{ Family } & $0.319^{* * *}$ & 0.055 & $0.255^{* *}$ & $0.073^{* *}$ & 0.084 & 0.002 \\
\hline & $(0.105)$ & $(0.039)$ & $(0.110)$ & $(0.036)$ & $(0.068)$ & $(0.039)$ \\
\hline \multirow[t]{2}{*}{ Private Chain } & $0.344^{* * *}$ & $0.080^{* *}$ & $0.279^{* *}$ & $0.058^{*}$ & $0.182^{* * *}$ & 0.007 \\
\hline & $(0.106)$ & $(0.036)$ & $(0.112)$ & $(0.033)$ & $(0.068)$ & $(0.037)$ \\
\hline \multirow[t]{2}{*}{ Public Co. } & $1.046^{* * *}$ & 0.069 & $0.989^{* * *}$ & 0.003 & $0.648^{* * *}$ & 0.013 \\
\hline & $(0.139)$ & $(0.047)$ & $(0.151)$ & $(0.049)$ & $(0.101)$ & $(0.053)$ \\
\hline \multirow[t]{2}{*}{ Other Fin. Firm } & 0.027 & -0.013 & -0.048 & -0.068 & 0.051 & -0.003 \\
\hline & $(0.120)$ & $(0.048)$ & $(0.122)$ & $(0.050)$ & $(0.080)$ & $(0.050)$ \\
\hline Observations & 12550 & 12542 & 12550 & 12542 & 12550 & 12542 \\
\hline Year FE & Yes & Yes & Yes & Yes & Yes & Yes \\
\hline Newspaper FE & No & Yes & No & Yes & No & Yes \\
\hline Outcome Mean & 1.187 & 1.187 & 1.148 & 1.148 & 2.526 & 2.526 \\
\hline
\end{tabular}

Panel D: Operations by Ownership Type with Private Equity as Base Group

\begin{tabular}{|c|c|c|c|c|c|c|}
\hline \multirow[t]{2}{*}{ Dependent Variable: } & \multicolumn{2}{|c|}{ Digitial circulation } & \multicolumn{2}{|c|}{ Circulation } & \multicolumn{2}{|c|}{ Shut Down } \\
\hline & (1) & (2) & (3) & (4) & (5) & (6) \\
\hline \multirow[t]{2}{*}{ Independent } & -0.757 & -0.339 & 0.090 & $0.078^{* * *}$ & $0.006^{* * *}$ & $0.008^{*}$ \\
\hline & $(0.756)$ & $(0.296)$ & $(0.095)$ & $(0.022)$ & $(0.002)$ & $(0.004)$ \\
\hline \multirow[t]{2}{*}{ Family } & $-1.329^{* *}$ & -0.251 & $0.200^{* *}$ & $0.096^{* * *}$ & $0.003^{* *}$ & $0.006^{* * *}$ \\
\hline & $(0.574)$ & $(0.272)$ & $(0.079)$ & (0.019) & $(0.001)$ & $(0.002)$ \\
\hline \multirow[t]{2}{*}{ Private Chain } & -0.554 & $-0.463^{*}$ & $0.226^{* * *}$ & $0.066^{* * *}$ & $0.013^{* * *}$ & $0.010^{* * *}$ \\
\hline & $(0.628)$ & $(0.251)$ & $(0.083)$ & $(0.019)$ & $(0.002)$ & $(0.003)$ \\
\hline \multirow[t]{2}{*}{ Public Co. } & -0.383 & $-0.424^{* *}$ & $0.629^{* * *}$ & $0.080^{* * *}$ & $0.003^{*}$ & 0.003 \\
\hline & $(0.553)$ & $(0.214)$ & $(0.084)$ & $(0.019)$ & $(0.002)$ & $(0.003)$ \\
\hline \multirow[t]{2}{*}{ Other Fin. Firm } & $-1.757^{* *}$ & $-0.854^{* *}$ & 0.001 & 0.027 & 0.002 & -0.000 \\
\hline & $(0.783)$ & $(0.382)$ & $(0.092)$ & $(0.032)$ & $(0.002)$ & $(0.003)$ \\
\hline Observations & 3286 & 3244 & 15217 & 15111 & 26858 & 26827 \\
\hline Year FE & Yes & Yes & Yes & Yes & Yes & Yes \\
\hline Newspaper FE & No & Yes & No & Yes & No & Yes \\
\hline Outcome Mean & 5.036 & 5.087 & 9.777 & 9.783 & 0.007 & 0.006 \\
\hline
\end{tabular}

Note: This table shows the relationship between major ownership types and employment in Panel A, and operations in Panel B. Private equity ownership represents the base group. For each outcome, the first column does not include newspaper fixed effects, so the coefficients show the average for each ownership type in the whole sample. The second column includes newspaper fixed effects, which means that the coefficient is identified only from newspapers that change to or from the ownership type. The dependent variables in Panel A are log employees of a certain occupation. The dependent variables in Panel B are the advertising rate in $\log$ dollars per open inch in columns $1-2, \log$ print circulation in columns $3-4$, and an indicator for the newspaper closing in a particular year in columns $5-6$. Standard errors are clustered by newspaper. $* * *$ denotes $\mathrm{p}$-value $<.01$, ** denotes p-value $<.05$, and $*$ denotes p-value $<.1$. 


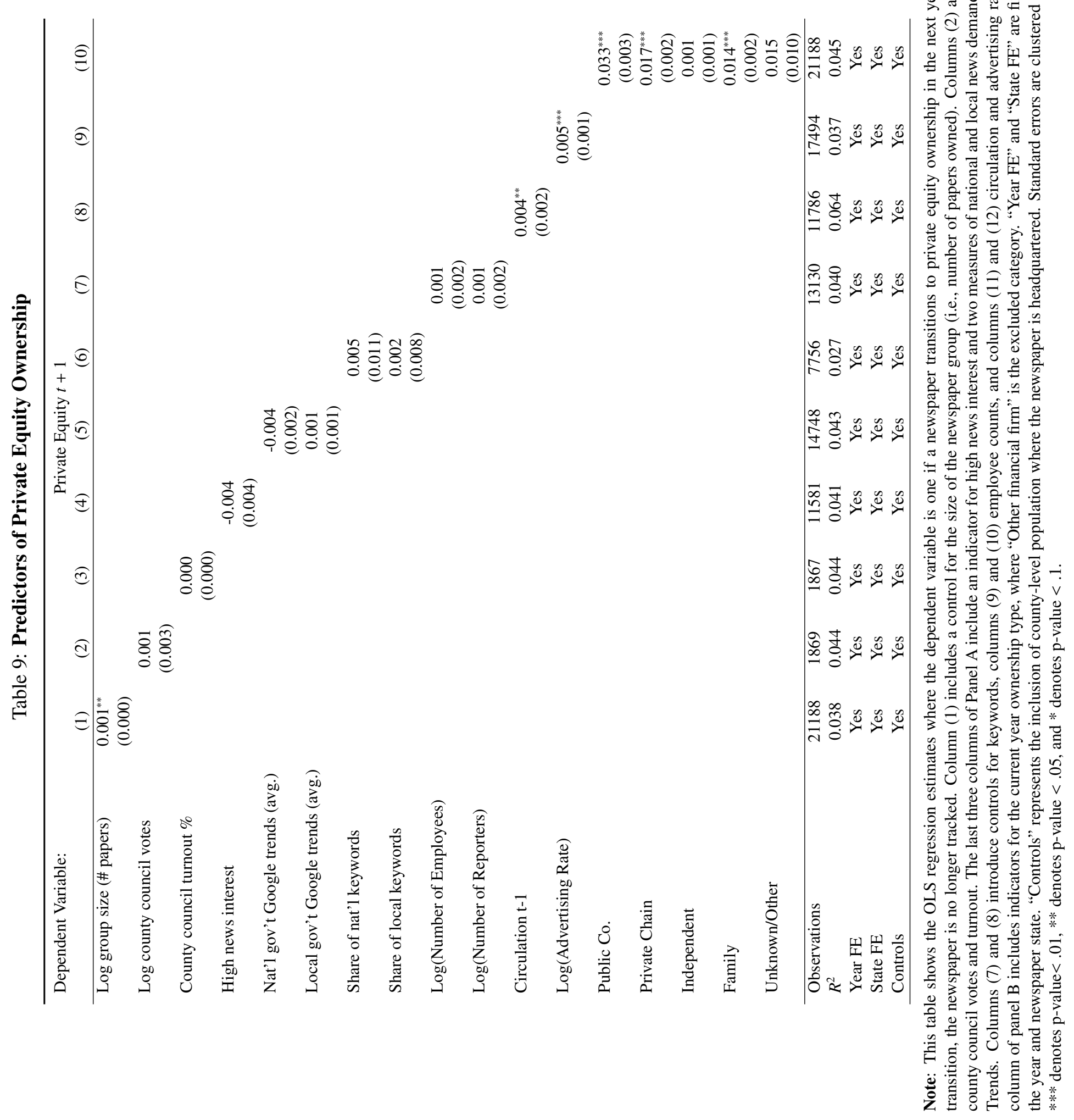


Table 10: Placebo Tests

\begin{tabular}{lccccc}
\hline & \multicolumn{2}{c}{ Panel A: Article Content } & & \\
Dependent Variable: & \multicolumn{2}{c}{ Share of Articles on } & & Number of Articles on \\
\cline { 2 - 3 } \cline { 5 - 6 } & Local & National & & Local & National \\
& $(1)$ & $(2)$ & & $(3)$ & $(4)$ \\
\hline Post (Placebo) X PE (Placebo) & -0.010 & -0.003 & & 0.020 & -0.010 \\
& $(0.013)$ & $(0.005)$ & & $(0.052)$ & $(0.069)$ \\
\hline Observations & 10952 & 10952 & & 10952 & 10952 \\
Year FE & Yes & Yes & & Yes & Yes \\
Newspaper FE & Yes & Yes & & Yes & Yes \\
Outcome Mean & 0.380 & 0.157 & & 8.046 & 6.972 \\
\hline
\end{tabular}

Panel B: Employees and Operations

\begin{tabular}{lcccc} 
Dependent Variable: & Reporters & Editors & Circ & Circ No Stale \\
& $(1)$ & $(2)$ & $(3)$ & $(4)$ \\
\hline Post (placebo) X PE (placebo) & 0.016 & -0.006 & -0.027 & -0.027 \\
& $(0.048)$ & $(0.049)$ & $(0.018)$ & $(0.018)$ \\
\hline Observations & 13282 & 13282 & 14766 & 14766 \\
Year FE & Yes & Yes & Yes & Yes \\
Newspaper FE & Yes & Yes & Yes & Yes \\
Outcome Mean & 2.542 & 1.191 & 9.796 & 9.796 \\
\hline
\end{tabular}

Panel C: Local Election Participation

\begin{tabular}{lccccc} 
Election Type: & \multicolumn{2}{c}{ County Council } & & \multicolumn{2}{c}{ Mayor } \\
\cline { 2 - 3 } \cline { 5 - 6 } Dependent Variable: & Log Total Votes & Turnout $(\%)$ & & Log Total Votes & Turnout (\%) \\
& $(1)$ & $(2)$ & & $(3)$ & $(4)$ \\
\hline Post (placebo) X PE (placebo) & 0.014 & -0.385 & & -0.083 & -0.117 \\
& $(0.098)$ & $(0.410)$ & & $(0.108)$ & $(0.426)$ \\
\hline Observations & 2109 & 2107 & & 1955 & 1955 \\
Year FE & Yes & Yes & & Yes & Yes \\
Newspaper FE & Yes & Yes & & Yes & Yes \\
Outcome Mean & 9.502 & 8.745 & & 8.850 & 4.644 \\
\hline
\end{tabular}

Note: This table shows placebo tests for the main outcomes. We randomly allocate PE deals and deal years to papers in the sample. The allocation of PE deals is done so that the fraction of papers with a PE deal in each year matches the original sample. Standard errors are clustered by newspaper. $* * *$ denotes $\mathrm{p}$-value $<.01$, ** denotes $\mathrm{p}$-value $<.05$, and $*$ denotes $\mathrm{p}$-value $<.1$. 
Appendix: For Online Publication 
Figure A.1: Example of E\&P Raw Data

U.S. Daily Newspapers

Alabama

I-3

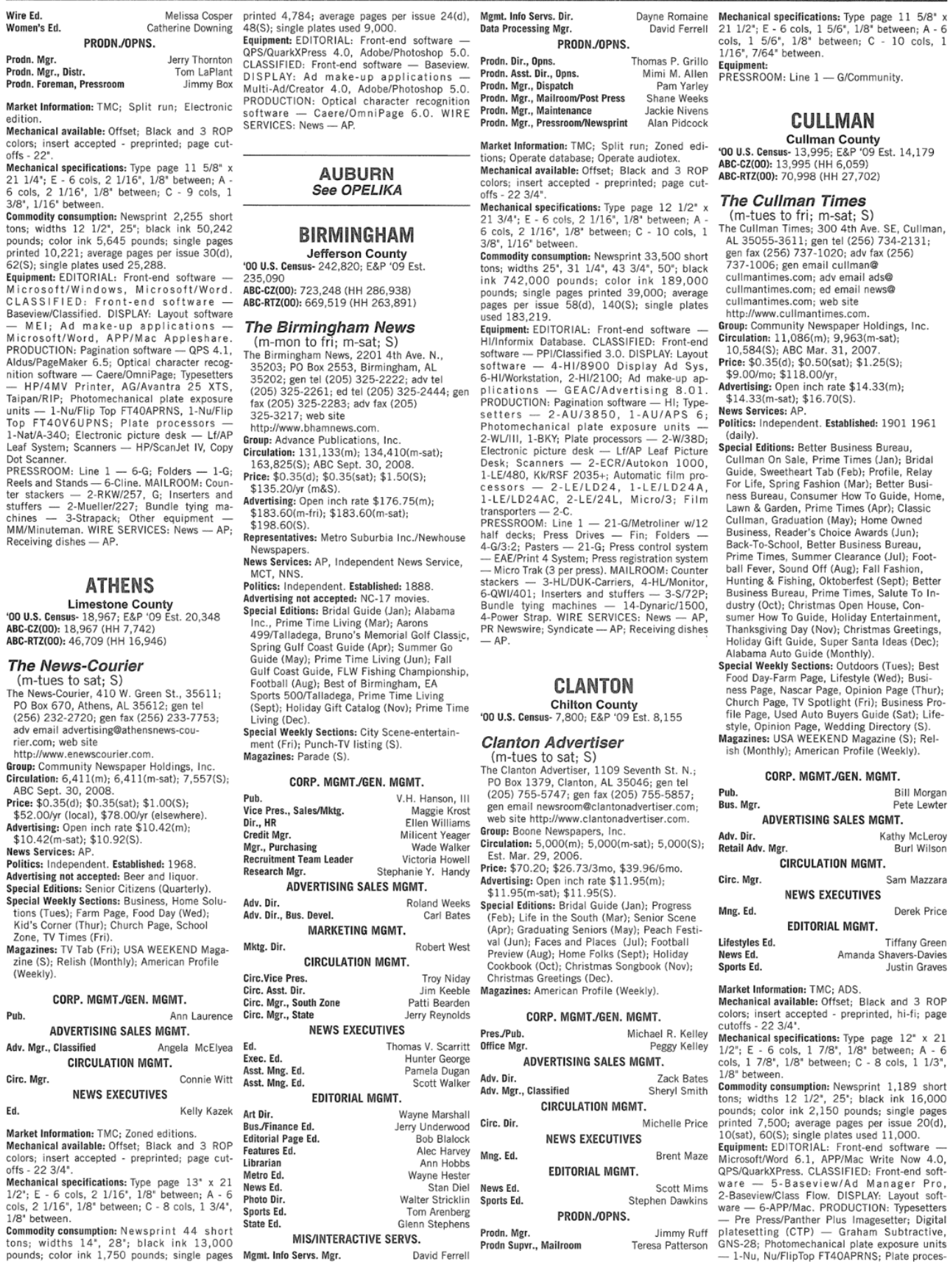

Note: This figure shows a page from the digitized E\&P Yearbooks. This representative page concerns newspapers in Alabama in 2009. 
Figure A.2: Difference-in-differences Event Study of Private Equity Ownership and Number of Articles by Content

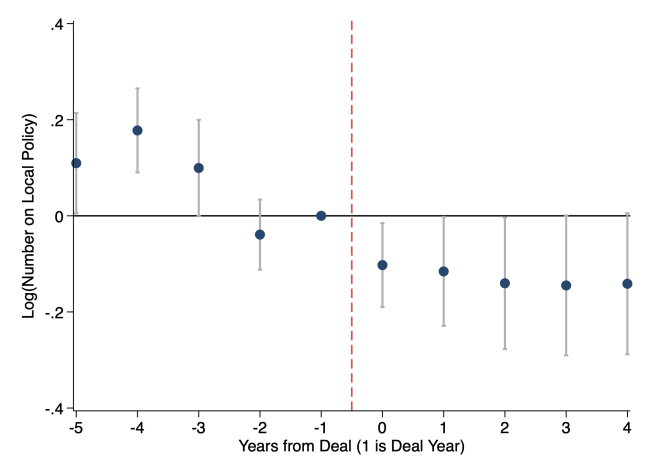

A. Local Government

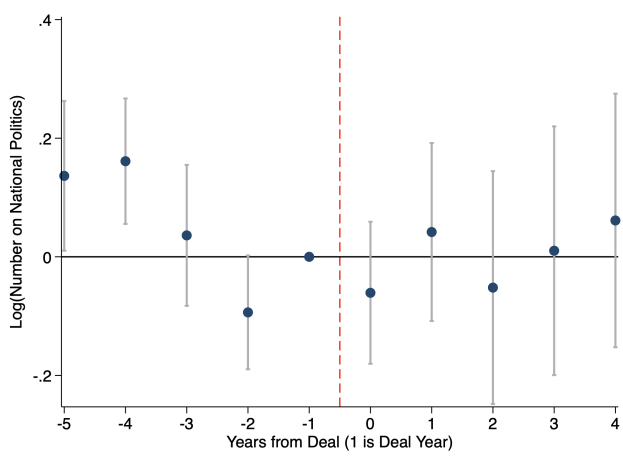

C. National Politics

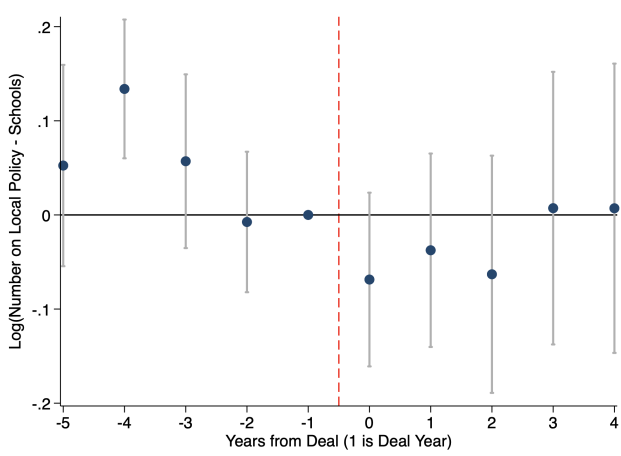

E. Schools

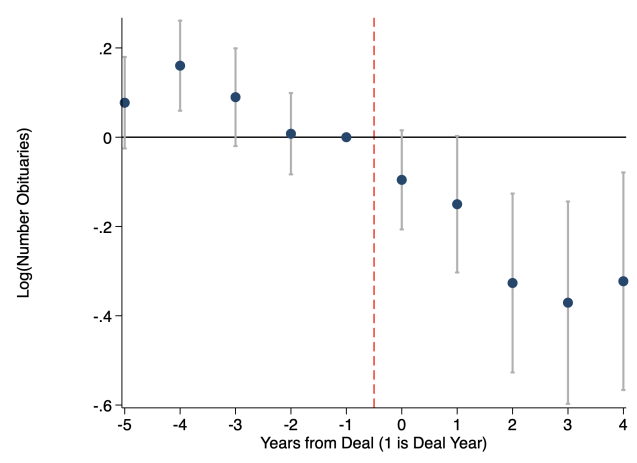

B. Obituaries

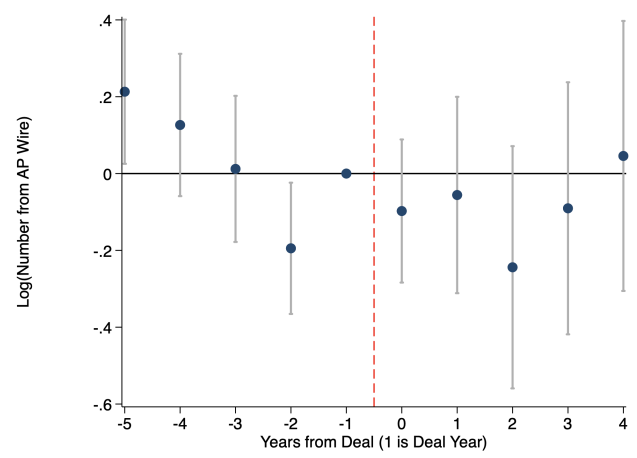

D. AP Wire

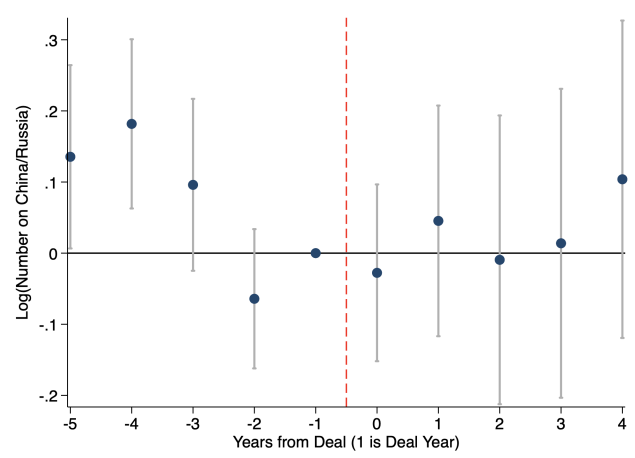

F. China/Russia

Note: This figure presents the difference-in-differences event studies around the time a newspaper experiences a private equity buyout. We leave out the year before the deal $(-1)$. The regression includes year and newspaper fixed effects, as well as dummies for each year around the buyout (34 total dummies). Only the coefficients for the years immediately around the buyout are shown in the graph. Local policy articles (Panel A) include any of the following words: city council, city hall, mayor, state senate, state legislature, zoning, planning board, board of education, school board, school district, municipal, sheriff, police, local policy. Obituaries (Panel B) include any of the following words: died, finally at peace, or passed away. National politics articles (Panel C) include any of the following words: Bush, Congress, Obama, Trump, White House, Democrat, Republican. AP Wire (Panel D) refers to syndicated articles from the Associated Press. Schools (Panel E) report the share of articles that have any mention of: board of education, school board, school district. China/Russia articles (Panel F) include any mentions of China or Russia. The final graph shows the total number of articles. For parsimony, we show the most important outcomes in our analysis. $95 \%$ confidence intervals shown. 
Figure A.3: Supplementary Difference-in-differences Event Studies on Effects of Private Equity Ownership

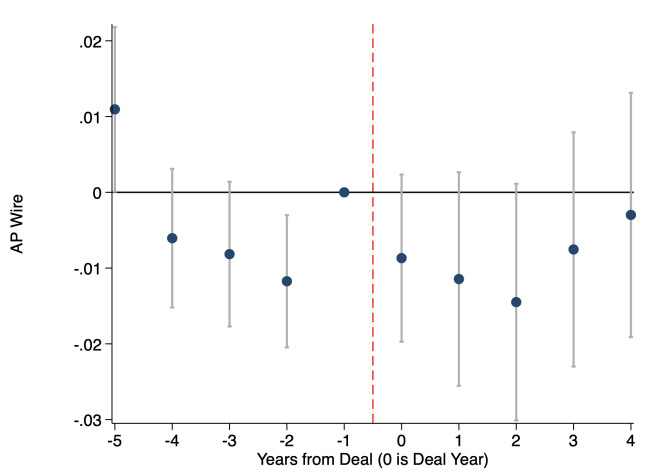

A. AP Wire Content Share

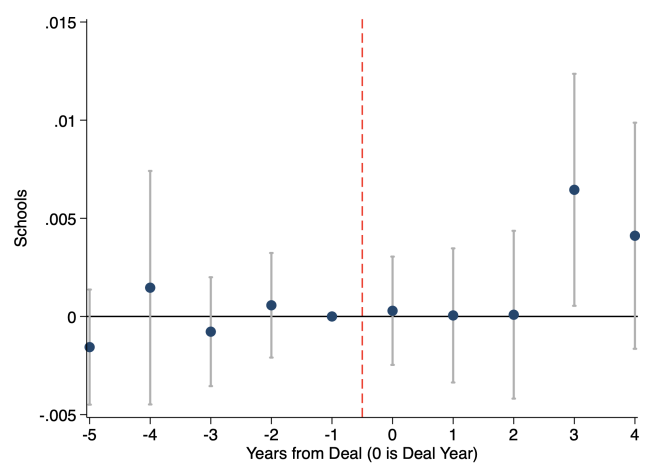

C. Schools Content Share

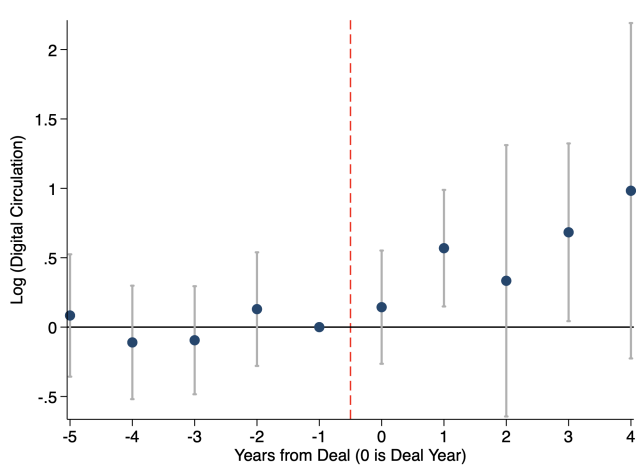

E. Log Digital Circulation

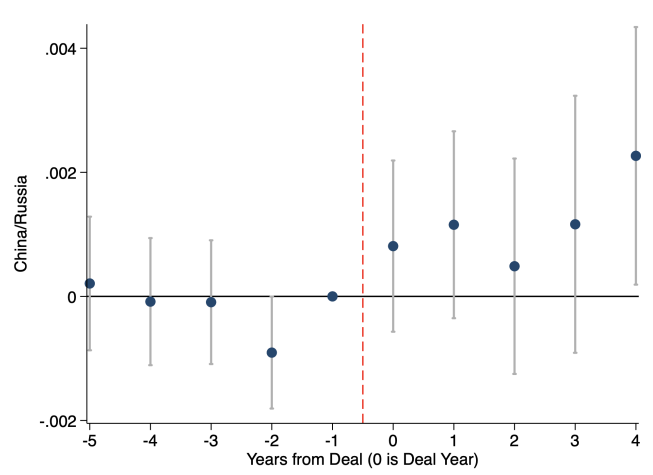

B. China/Russia Content Share

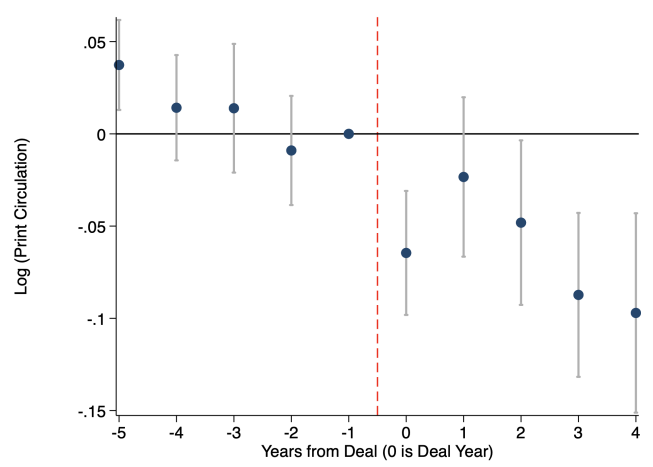

D. Log Print Circulation

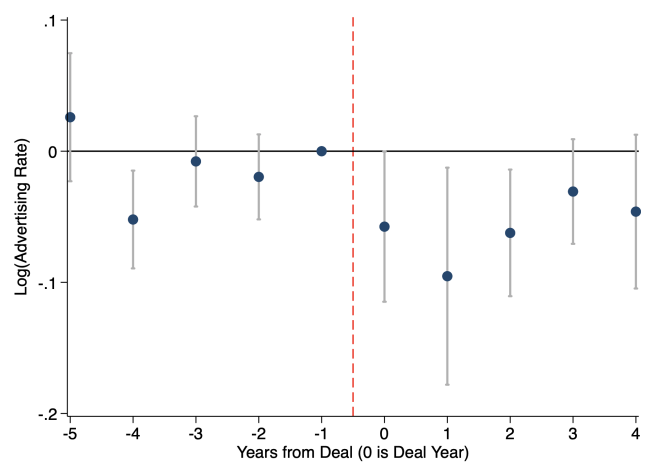

F. Log Advertising Rate (Dollars per Square Inch)

Note: This figure presents the difference-in-differences event studies around the time a newspaper experiences a private equity buyout. We leave out the year before the deal $(-1)$. The regression includes year and newspaper fixed effects, as well as dummies for each year around the buyout (34 total dummies). Only the coefficients for the years immediately around the buyout are shown in the graph. Article content outcomes are in Panels A-C. AP Wire (Panel A) refers to syndicated articles from the Associated Press. China/Russia articles (Panel B) include any mentions of China or Russia. Schools (Panel C) report the share of articles that have any mention of: board of education, school board, school district. Operational outcomes are in Panels D-F. In Panel D, the dependent variable is log print circulation. In Panel E, it is digital circulation. As there is concern that circulation are imputed from year to year, leading to stale data, we estimate the effects in the sample in which there is an observed change in circulation from the previous year. In Panel C, the dependent variable is the log advertising rate in dollars per open inch. $95 \%$ confidence intervals shown. 


\section{Figure A.4: Raw Mean Event Study Private Equity Ownership for Key Outcomes}

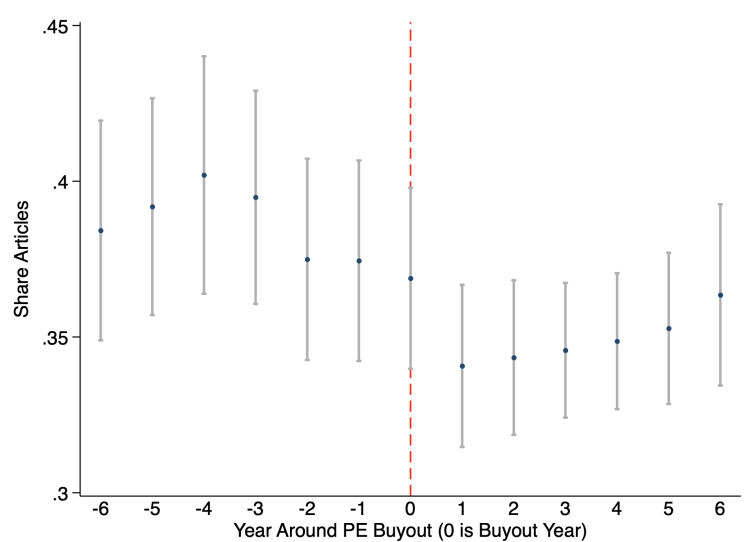

A. Share Articles on Local Government

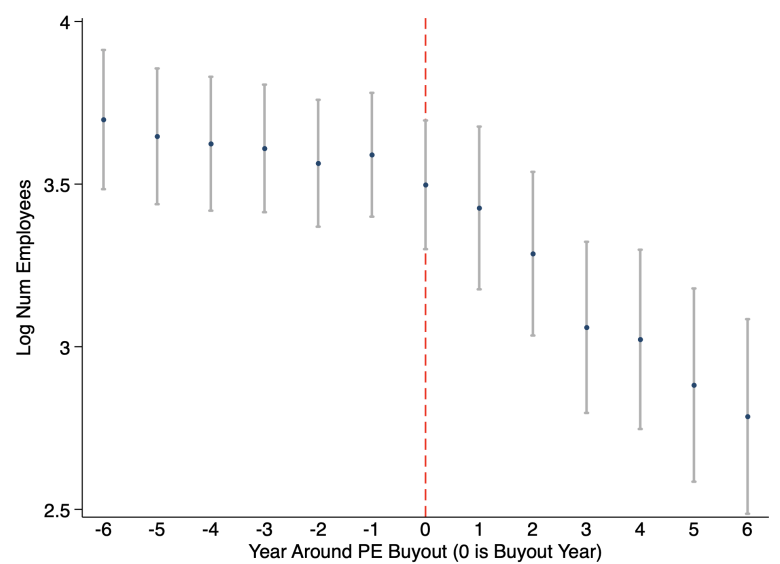

C. Employees

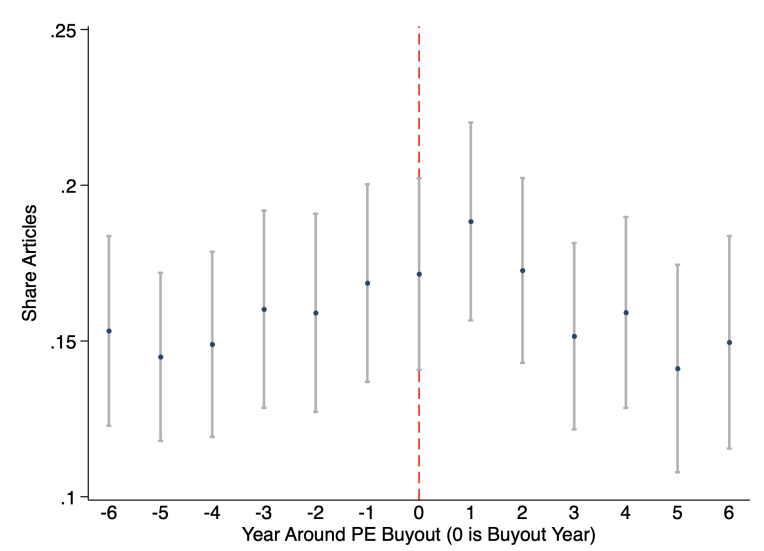

B. Share Articles on National Politics

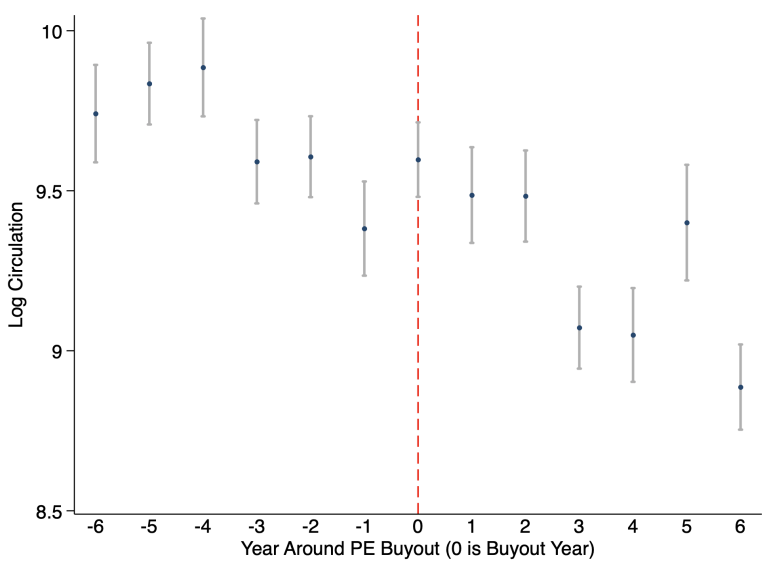

D. Circulation

Note: This figure presents the event studies around the time a newspaper experiences a private equity buyout. The graph shows raw means of the dependent variable. For parsimony, we show only key outcomes, though results are similar to the main findings for other outcomes. The sample is restricted to newspapers acquired by private equity firms. $95 \%$ confidence intervals shown. 
Figure A.5: Difference-in-differences Event Study of Private Equity Ownership and Share of Articles by Content (longer time series)

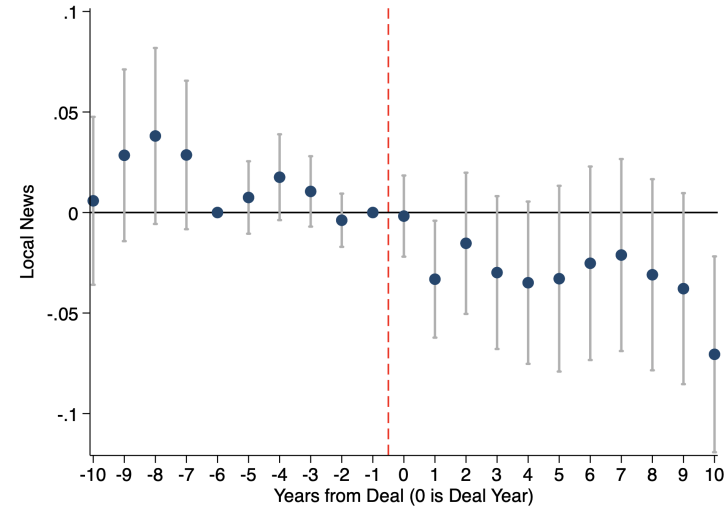

A. Local Gov't

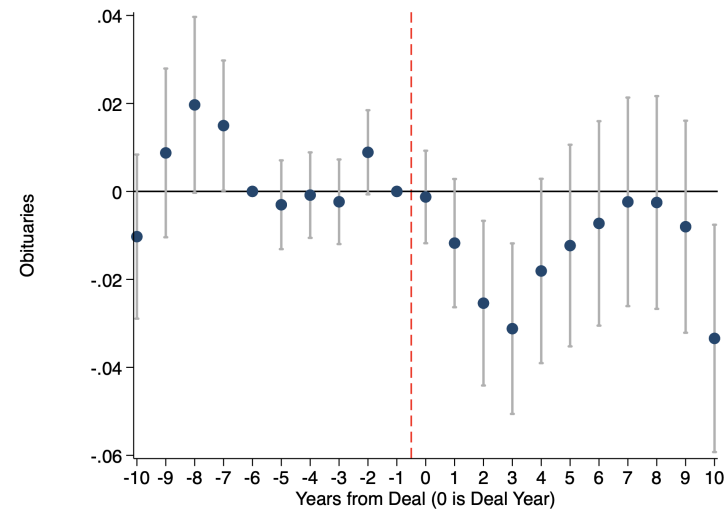

C. Obituaries

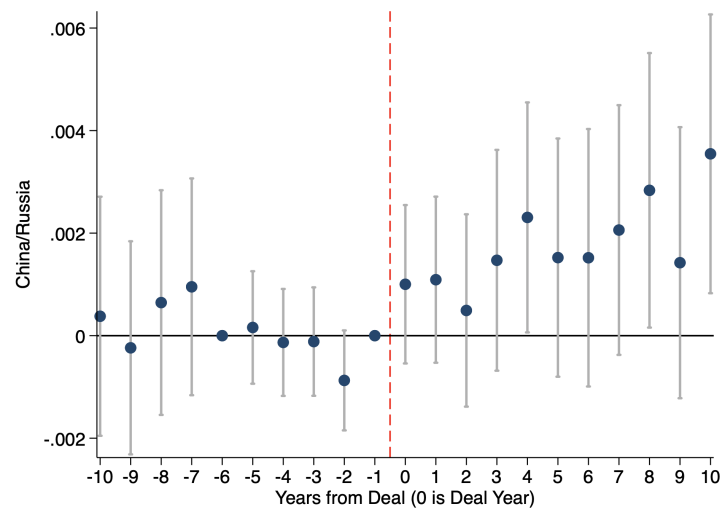

E. China/Russia

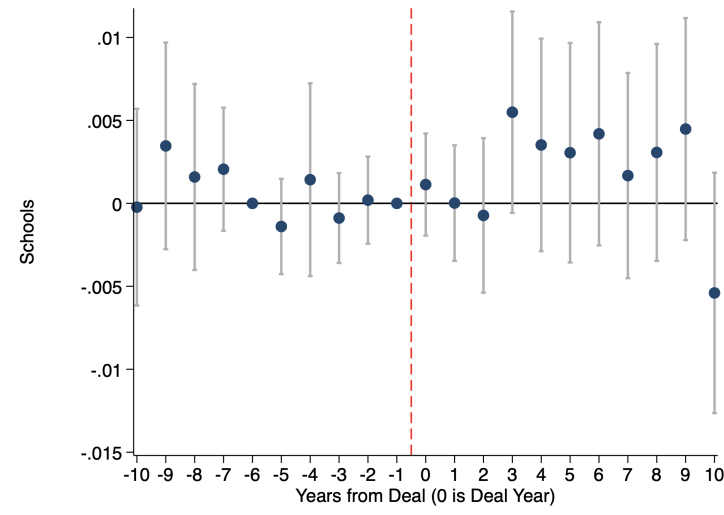

B. Schools

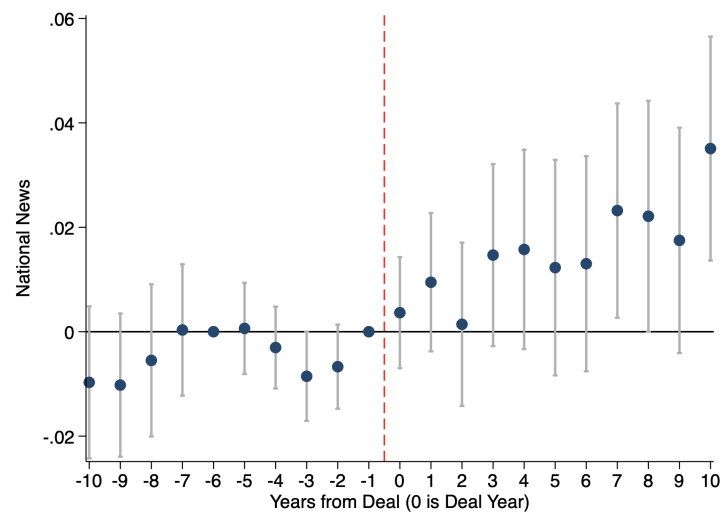

D. National Politics

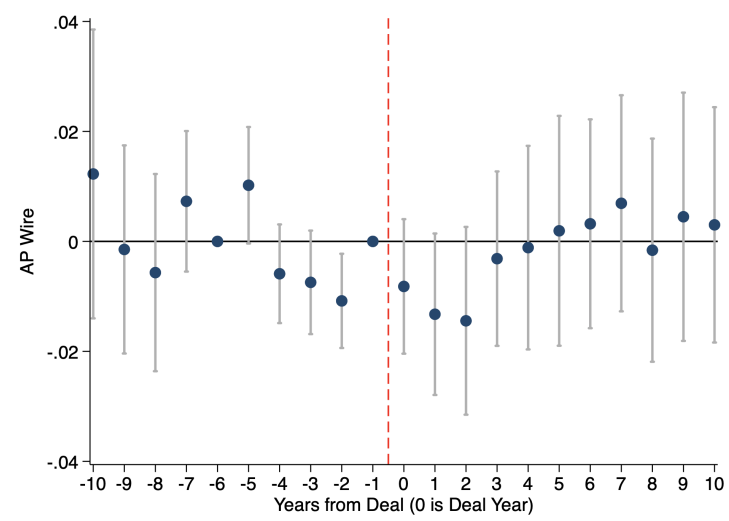

F. AP Wire

Note: This figure presents the difference-in-differences event studies around the time a newspaper experiences a private equity buyout. We leave out the year before the deal $(-1)$. The regression includes year, newspaper, and deal fixed effects, as well as dummies for each year around the buyout (34 total dummies). Only the coefficients for the years immediately around the buyout are shown in the graph. In each figure, the dependent variable is the log number of articles with particular element of content, defined as in Figure 3. The final graph shows the total number of articles. For parsimony, we show the most important outcomes in our analysis. $95 \%$ confidence intervals shown. 


\section{Figure A.6: Difference-in-differences Event Study of Private Equity Ownership and Local Preferences via Google Trends}

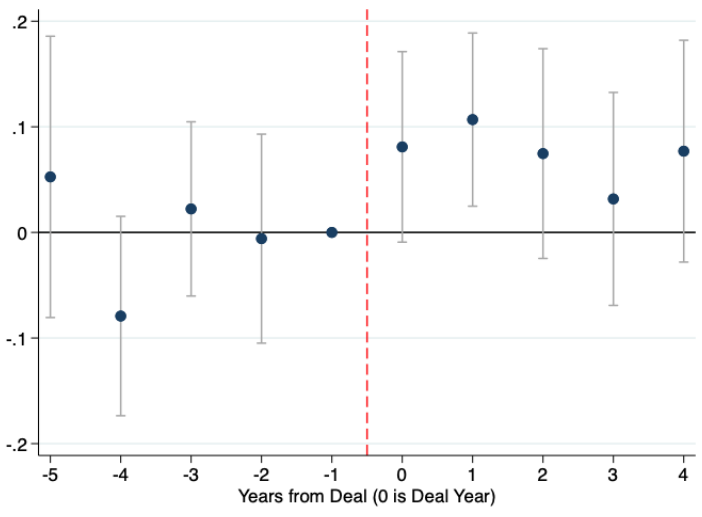

A. Local Government (Mean)

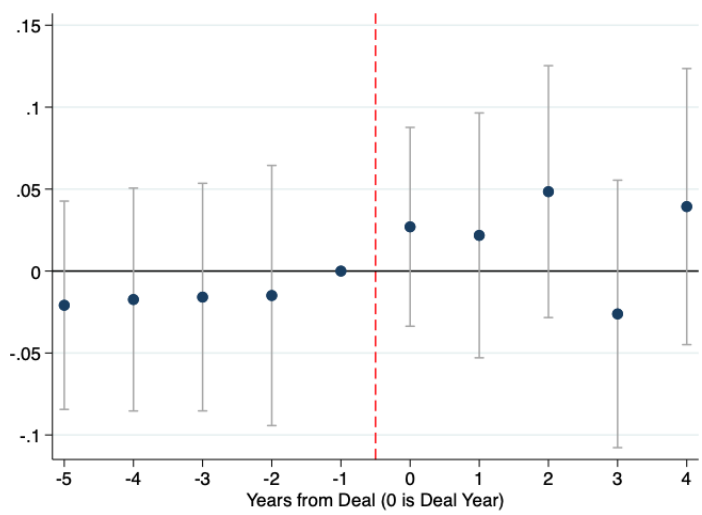

C. National Politics (Mean)

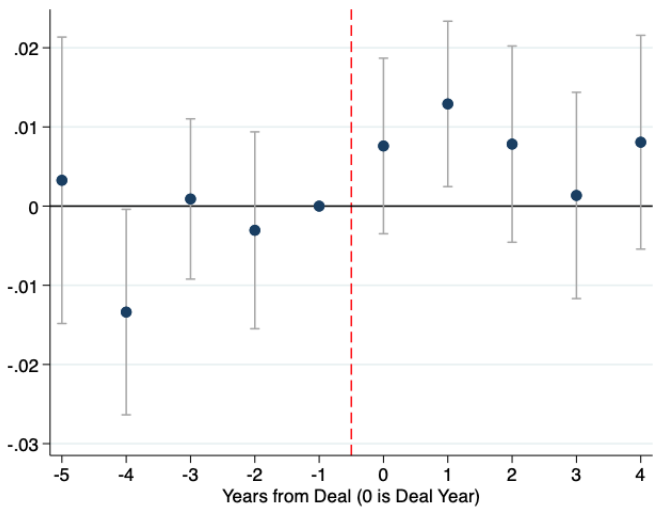

B. Local Government (Sum)

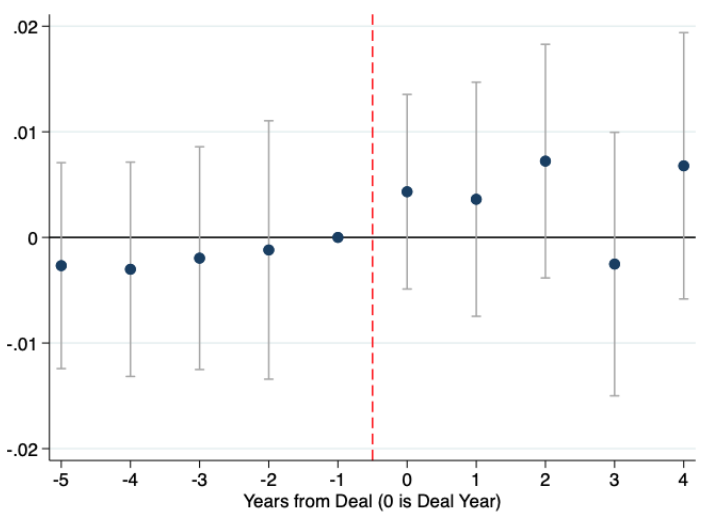

D. National Politics (Sum)

Note: This figure presents the difference-in-differences event studies around the time a newspaper experiences a private equity buyout. We leave out the year before the deal $(-1)$. The regression includes year and newspaper fixed effects, as well as dummies for each year around the buyout (34 total dummies). Only the coefficients for the years immediately around the buyout are shown in the graph. The dependent variables are local Google search trends for the local and national keywords. In Panels $\mathrm{A}$ and $\mathrm{C}$, the dependent variables are constructed as means of the keyword search intensity across all the keywords in our local and national government measures from Table 4 columns 1 and 3. In Panels B and D, the dependent variables are constructed the same way except as sums. All specifications are otherwise identical to those in Table 4. The sample is smaller because the Google trends data are only available starting in 2006. Google search trend data is at the DMA level. 95\% confidence intervals shown. 
Table A.1: Robustness Tests of Private Equity Ownership and Political Outcomes

\begin{tabular}{|c|c|c|c|c|c|c|}
\hline \multirow{3}{*}{$\begin{array}{l}\text { Fixed Effects: } \\
\text { Dependent Variable: }\end{array}$} & \multicolumn{5}{|c|}{ Panel A: Local Participation in Sheriff Elections } & \\
\hline & \multicolumn{3}{|c|}{ Newspaper } & \multicolumn{3}{|c|}{ County } \\
\hline & Total Votes & $\begin{array}{l}\text { Log Total } \\
\text { Votes }\end{array}$ & Turnout (\%) & Total Votes & $\begin{array}{l}\text { Log Total } \\
\text { Votes }\end{array}$ & Turnout (\%) \\
\hline & (1) & (2) & (3) & (4) & (5) & (6) \\
\hline Post deal X PE & $\begin{array}{l}-3.305 \\
(2.531)\end{array}$ & $\begin{array}{l}-0.017 \\
(0.052)\end{array}$ & $\begin{array}{c}-0.208 \\
(1.338)\end{array}$ & $\begin{array}{l}-1.953 \\
(2.148)\end{array}$ & $\begin{array}{l}-0.003 \\
(0.044)\end{array}$ & $\begin{array}{l}-0.160 \\
(1.180)\end{array}$ \\
\hline Observations & 489 & 489 & 489 & 461 & 461 & 461 \\
\hline$R^{2}$ & 0.263 & 0.466 & 0.537 & 0.983 & 0.986 & 0.835 \\
\hline Year FE & Yes & Yes & Yes & Yes & Yes & Yes \\
\hline Newspaper FE & Yes & Yes & Yes & Yes & Yes & Yes \\
\hline County FE & No & No & No & Yes & Yes & Yes \\
\hline Outcome Mean & 47.368 & 10.253 & 29.964 & 47.467 & 10.254 & 29.954 \\
\hline
\end{tabular}

Panel B: Local Election Participation with County Fixed Effects

\begin{tabular}{|c|c|c|c|c|c|c|}
\hline \multirow{2}{*}{$\begin{array}{l}\text { Election Type: } \\
\text { Dependent Variable: }\end{array}$} & \multicolumn{3}{|c|}{ County Council } & \multicolumn{3}{|c|}{ Mayor } \\
\hline & Total Votes & $\begin{array}{c}\text { Log Total } \\
\text { Votes }\end{array}$ & Turnout (\%) & Total Votes & $\begin{array}{l}\text { Log Total } \\
\text { Votes }\end{array}$ & Turnout (\%) \\
\hline & (1) & (2) & (3) & (4) & (5) & (6) \\
\hline Post deal X PE & $\begin{array}{l}-1.492 \\
(0.914)\end{array}$ & $\begin{array}{l}-0.065 \\
(0.040)\end{array}$ & $\begin{array}{l}-0.401^{*} \\
(0.208)\end{array}$ & $\begin{array}{l}-1.980 \\
(2.402)\end{array}$ & $\begin{array}{l}-0.125^{*} \\
(0.064)\end{array}$ & $\begin{array}{l}-0.220 \\
(0.178)\end{array}$ \\
\hline Observations & 2112 & 2112 & 2110 & 1947 & 1947 & 1947 \\
\hline$R^{2}$ & 0.781 & 0.838 & 0.830 & 0.481 & 0.770 & 0.651 \\
\hline Year FE & Yes & Yes & Yes & Yes & Yes & Yes \\
\hline County FE & Yes & Yes & Yes & Yes & Yes & Yes \\
\hline Outcome Mean & 32.364 & 9.499 & 8.749 & 26.188 & 8.850 & 4.628 \\
\hline
\end{tabular}

Note: This table shows the relationship between private equity ownership and political outcomes. In Panel A, we consider sheriff elections, where the data are much sparser. The first three columns use the main specification with newspaper fixed effects, while the latter three use county fixed effects. In Panel B, we consider two types of local elections: county legislature (columns 1-3) and mayoral (columns 4-6) elections. Total votes are in thousands. Turnout is defined as total votes divided by the local population (based on U.S. Census data). The specification includes county fixed effects. $* * *$ denotes p-value $<.01$, $* *$ denotes $\mathrm{p}$-value $<.05$, and $*$ denotes $\mathrm{p}$-value $<.1$. 
Table A.2: Private Equity Ownership and Article Content, Supplementary Outcomes

\begin{tabular}{|c|c|c|c|c|}
\hline Dependent Variable: & \multicolumn{2}{|c|}{ Schools } & \multicolumn{2}{|c|}{ China/Russia } \\
\hline Measure: & $\begin{array}{l}\text { Share } \\
\text { (1) }\end{array}$ & $\begin{array}{l}\text { All } \\
(2)\end{array}$ & $\begin{array}{l}\text { Share } \\
\text { (3) }\end{array}$ & $\begin{array}{l}\text { All } \\
\text { (4) }\end{array}$ \\
\hline Post deal X PE & $\begin{array}{c}0.002 \\
(0.002)\end{array}$ & $\begin{array}{c}-0.127^{* *} \\
(0.051)\end{array}$ & $\begin{array}{c}0.001 \\
(0.001)\end{array}$ & $\begin{array}{l}-0.120 \\
(0.084)\end{array}$ \\
\hline Observations & 10952 & 10952 & 10952 & 10952 \\
\hline$R^{2}$ & 0.613 & 0.746 & 0.742 & 0.753 \\
\hline Year FE & Yes & Yes & Yes & Yes \\
\hline Newspaper FE & Yes & Yes & Yes & Yes \\
\hline Outcome Mean & 0.049 & 5.926 & 0.017 & 4.809 \\
\hline
\end{tabular}

Note: This table shows the impact of private equity buyouts on the share (columns 1, 3) and $\log$ number (columns 2, 4) of a newspaper's total articles that fall into a particular topic area (a single article can cover multiple topics). Local policy "school" articles (columns 1-2) include: board of education, school board, and school district. China/Russia (columns 3-4) articles include either the words China or Russia. Standard errors are clustered by newspaper. $* * *$ denotes p-value $<.01$, ** denotes p-value $<.05$, and $*$ denotes $\mathrm{p}$-value $<.1$. 
Table A.3: Selection regression robustness: digital subscriptions

\begin{tabular}{|c|c|c|c|c|c|c|c|}
\hline \multirow[t]{2}{*}{ Dependent Variable: } & \multicolumn{6}{|c|}{ Private Equity $t+1$} & \multirow[b]{2}{*}{ (7) } \\
\hline & (1) & (2) & (3) & (4) & (5) & $(6)$ & \\
\hline Circulation $\mathrm{t}-1$ & $\begin{array}{l}0.003^{* *} \\
(0.001)\end{array}$ & & & $\begin{array}{l}-0.000 \\
(0.001)\end{array}$ & & & $\begin{array}{l}-0.009 \\
(0.006)\end{array}$ \\
\hline Log digital $t-1$ & & $\begin{array}{l}0.002^{* *} \\
(0.001)\end{array}$ & & & $\begin{array}{c}0.001 \\
(0.001)\end{array}$ & & \\
\hline Digital to Print Subscribers t-1 & & & $\begin{array}{l}0.023^{* *} \\
(0.010)\end{array}$ & & & $\begin{array}{c}0.012 \\
(0.010)\end{array}$ & $\begin{array}{c}0.024^{*} \\
(0.013)\end{array}$ \\
\hline Public Co. & & & & $\begin{array}{c}0.037^{* * *} \\
(0.003)\end{array}$ & $\begin{array}{c}0.076^{* * *} \\
(0.011)\end{array}$ & $\begin{array}{c}0.076^{* * *} \\
(0.011)\end{array}$ & $\begin{array}{c}0.078^{* * *} \\
(0.012)\end{array}$ \\
\hline Private Chain & & & & $\begin{array}{c}0.022^{* * *} \\
(0.003)\end{array}$ & $\begin{array}{c}0.053^{* * *} \\
(0.012)\end{array}$ & $\begin{array}{c}0.053^{* * *} \\
(0.012)\end{array}$ & $\begin{array}{c}0.053^{* * *} \\
(0.012)\end{array}$ \\
\hline Independent & & & & $\begin{array}{c}0.001 \\
(0.002)\end{array}$ & $\begin{array}{c}-0.002 \\
(0.011)\end{array}$ & $\begin{array}{l}-0.002 \\
(0.011)\end{array}$ & $\begin{array}{c}-0.000 \\
(0.011)\end{array}$ \\
\hline Family & & & & $\begin{array}{c}0.016^{* * *} \\
(0.002)\end{array}$ & $\begin{array}{c}0.011 \\
(0.008)\end{array}$ & $\begin{array}{c}0.011 \\
(0.008)\end{array}$ & $\begin{array}{c}0.014 \\
(0.008)\end{array}$ \\
\hline Unknown/Other & & & & $\begin{array}{c}0.016 \\
(0.012)\end{array}$ & $\begin{array}{l}-0.043 \\
(0.031)\end{array}$ & $\begin{array}{c}-0.043 \\
(0.031)\end{array}$ & $\begin{array}{c}-0.044 \\
(0.033)\end{array}$ \\
\hline Observations & 16604 & 2301 & 2301 & 16604 & 2301 & 2301 & 2301 \\
\hline$R^{2}$ & 0.039 & 0.119 & 0.119 & 0.047 & 0.144 & 0.144 & 0.145 \\
\hline Year FE & Yes & Yes & Yes & Yes & Yes & Yes & Yes \\
\hline State FE & Yes & Yes & Yes & Yes & Yes & Yes & Yes \\
\hline Controls & Yes & Yes & Yes & Yes & Yes & Yes & Yes \\
\hline
\end{tabular}

Note: The table repeats the analysis from Table 9 with the addition of measures of digital circulation. All regressions include the county-level population controls. "Log digital $\mathrm{t}-1$ " is the log of paid digital subscription in the previous year and "Digital to Print Subscribers t-1" is the ratio of digital to print subscriptions in the previous year. Standard errors are clustered by newspaper. $* * *$ denotes p-value $<.01, * *$ denotes p-value $<.05$, and $*$ denotes p-value $<.1$. 


\section{Table A.4: Effects of Private Equity on Subscription, Across Pre-Existing Digital Share}

\begin{tabular}{lccc}
\hline \multirow{2}{*}{ Dependent Variable: } & \multicolumn{3}{c}{ Log of digital circulation } \\
& $(1)$ & $(2)$ & $(3)$ \\
\hline Post deal X PE & $0.364^{*}$ & 0.240 & -0.032 \\
& $(0.208)$ & $(0.259)$ & $(0.186)$ \\
\hline Observations & 3287 & 2555 & 732 \\
$R^{2}$ & 0.102 & 0.085 & 0.055 \\
Year FE & Yes & Yes & Yes \\
Newspaper FE & Yes & Yes & Yes \\
Outcome Mean & 0.481 & 0.339 & 0.965 \\
Sample & All & $<$ Median & $>=$ Median \\
\hline
\end{tabular}

Note: The table repeats the analysis of the impact of private equity ownership on digital circulation. Column 1 repeats the digital circulation result in Table 6 . The remaining columns split that sample by the in-sample median of digital circulation to print circulation ratio. Standard errors are clustered by newspaper. $* * *$ denotes p-value $<.01$, ** denotes $\mathrm{p}$-value $<.05$, and $*$ denotes p-value $<.1$. 
Table A.5: Private Equity Ownership and Article Content: Survivor Newspapers Only

\begin{tabular}{lcccc}
\hline \multicolumn{5}{c}{ Panel A: Share of Articles } \\
\\
Dependent Variable: & Local Government & Obituaries & National Politics & AP Wire \\
& $(1)$ & $(2)$ & $(3)$ & $(4)$ \\
\hline Post deal X PE & $-0.036^{* *}$ & $-0.013^{*}$ & $0.012^{*}$ & -0.008 \\
& $(0.015)$ & $(0.008)$ & $(0.007)$ & $(0.007)$ \\
\hline Observations & 9945 & 9945 & 9945 & 9945 \\
Year FE & Yes & Yes & Yes & Yes \\
Newspaper FE & Yes & Yes & Yes & Yes \\
Outcome Mean & 0.332 & 0.140 & 0.161 & 0.051 \\
\hline
\end{tabular}

Panel B: Log Number of Articles

\begin{tabular}{lccccc} 
Dependent Variable: & Local Government & Obituaries & National Politics & AP Wire & Total \\
& & & & & \\
& $(1)$ & $(2)$ & $(3)$ & $(4)$ & $(5)$ \\
\hline Post deal X PE & $-0.248^{* * *}$ & $-0.327^{* * *}$ & -0.105 & -0.213 & $-0.167^{* * *}$ \\
& $(0.055)$ & $(0.084)$ & $(0.083)$ & $(0.132)$ & $(0.056)$ \\
\hline Observations & 9945 & 9945 & 9945 & 9945 & 9945 \\
Year FE & Yes & Yes & Yes & Yes & Yes \\
Newspaper FE & Yes & Yes & Yes & Yes & Yes \\
Outcome Mean & 7.943 & 6.989 & 7.043 & 5.356 & 9.168 \\
\hline
\end{tabular}

Note: This table shows the impact of private equity buyouts on news content, where the sample is limited to newspapers that survived to the end of the sample. $* * *$ denotes $\mathrm{p}$-value $<.01$, $* *$ denotes $\mathrm{p}$-value $<.05$, and $*$ denotes p-value $<.1$. 
Table A.6: Private Equity Ownership and Employees: Survivor \& Digital Newspapers Only

\begin{tabular}{|c|c|c|c|c|}
\hline \multicolumn{5}{|c|}{ Panel A: Sample Limited to Survivor Newspapers } \\
\hline \multirow[t]{2}{*}{ Dependent Variable: } & Reporters & Editors & $\begin{array}{c}\text { Interns \& } \\
\text { Freelancers }\end{array}$ & Employees \\
\hline & $(1)$ & $(2)$ & (3) & (4) \\
\hline Post deal X PE & $\begin{array}{l}-0.076^{*} \\
(0.040)\end{array}$ & $\begin{array}{c}-0.094^{* * *} \\
(0.035)\end{array}$ & $\begin{array}{l}-0.003 \\
(0.042)\end{array}$ & $\begin{array}{c}-0.075^{* *} \\
(0.038)\end{array}$ \\
\hline Observations & 12391 & 12391 & 12391 & 12391 \\
\hline$R^{2}$ & 0.093 & 0.046 & 0.132 & 0.183 \\
\hline Year FE & Yes & Yes & Yes & Yes \\
\hline Newspaper FE & Yes & Yes & Yes & Yes \\
\hline Outcome Mean & 1.205 & 1.736 & 0.528 & 2.563 \\
\hline \multicolumn{5}{|c|}{ Panel B: Sample Limited to Survivor \& Digital Newspapers } \\
\hline \multirow[t]{2}{*}{ Dependent Variable: } & Reporters & Editors & $\begin{array}{c}\text { Interns \& } \\
\text { Freelancers }\end{array}$ & Employees \\
\hline & (1) & (2) & (3) & (4) \\
\hline Post deal X PE & $\begin{array}{c}-0.143^{* *} \\
(0.060)\end{array}$ & $\begin{array}{l}-0.073 \\
(0.053)\end{array}$ & $\begin{array}{c}0.118 \\
(0.074)\end{array}$ & $\begin{array}{l}-0.094^{*} \\
(0.050)\end{array}$ \\
\hline Observations & 3488 & 3488 & 3488 & 3488 \\
\hline$R^{2}$ & 0.063 & 0.131 & 0.168 & 0.132 \\
\hline Year FE & Yes & Yes & Yes & Yes \\
\hline Newspaper FE & Yes & Yes & Yes & Yes \\
\hline Outcome Mean & 2.193 & 2.549 & 1.149 & 3.922 \\
\hline
\end{tabular}

Note: This table shows the impact of private equity buyouts on employees. In Panel A, the sample is limited to newspapers that survived to the end of the sample. In Panel B, the sample is further limited to survivor newspapers that also have at least some digital circulation. $* * *$ denotes $\mathrm{p}$-value $<.01$, ** denotes $\mathrm{p}$-value $<.05$, and $*$ denotes $\mathrm{p}$-value $<.1$. 


\section{Table A.7: Private Equity Ownership and Local Elections: Survivor \& Digital Newspapers Only}

\begin{tabular}{|c|c|c|c|c|c|c|}
\hline \multirow{3}{*}{$\begin{array}{l}\text { Election Type: } \\
\text { Dependent Variable: }\end{array}$} & \multicolumn{5}{|c|}{ Panel A: Sample Limited to Survivor Newspapers } & \\
\hline & \multicolumn{3}{|c|}{ County Council } & \multicolumn{3}{|c|}{ Mayor } \\
\hline & Total Votes & $\begin{array}{l}\text { Log Total } \\
\text { Votes }\end{array}$ & Turnout (\%) & Total Votes & $\begin{array}{l}\text { Log Total } \\
\text { Votes }\end{array}$ & Turnout $(\%)$ \\
\hline & (1) & (2) & (3) & (4) & $(5)$ & (6) \\
\hline Post deal X PE & $\begin{array}{l}-3.021^{*} \\
(1.698)\end{array}$ & $\begin{array}{l}-0.135^{*} \\
(0.079)\end{array}$ & $\begin{array}{c}-0.831^{* *} \\
(0.414)\end{array}$ & $\begin{array}{l}-0.519 \\
(4.118)\end{array}$ & $\begin{array}{l}-0.165^{*} \\
(0.099)\end{array}$ & $\begin{array}{l}-0.183 \\
(0.299)\end{array}$ \\
\hline Observations & 1899 & 1899 & 1897 & 1772 & 1772 & 1772 \\
\hline$R^{2}$ & 0.276 & 0.173 & 0.070 & 0.150 & 0.074 & 0.031 \\
\hline Year FE & Yes & Yes & Yes & Yes & Yes & Yes \\
\hline Newspaper FE & Yes & Yes & Yes & Yes & Yes & Yes \\
\hline Outcome Mean & 31.535 & 9.451 & 8.984 & 24.702 & 8.780 & 4.693 \\
\hline \multicolumn{7}{|c|}{ Panel B: Sample Limited to Survivor \& Digital Newspapers } \\
\hline Election Type: & \multicolumn{3}{|c|}{ County Council } & \multicolumn{3}{|c|}{ Mayor } \\
\hline Dependent Variable: & Total Votes & $\begin{array}{l}\text { Log Total } \\
\text { Votes }\end{array}$ & Turnout (\%) & Total Votes & $\begin{array}{l}\text { Log Total } \\
\text { Votes }\end{array}$ & Turnout (\%) \\
\hline & (1) & (2) & (3) & (4) & (5) & (6) \\
\hline Post deal X PE & $\begin{array}{l}-3.243 \\
(2.291)\end{array}$ & $\begin{array}{l}-0.122 \\
(0.094)\end{array}$ & $\begin{array}{l}-0.459 \\
(0.740)\end{array}$ & $\begin{array}{l}-7.753 \\
(9.620)\end{array}$ & $\begin{array}{c}-0.390^{* *} \\
(0.171)\end{array}$ & $\begin{array}{l}-0.825 \\
(0.515)\end{array}$ \\
\hline Observations & 535 & 535 & 535 & 497 & 497 & 497 \\
\hline$R^{2}$ & 0.328 & 0.289 & 0.065 & 0.177 & 0.128 & 0.057 \\
\hline Year FE & Yes & Yes & Yes & Yes & Yes & Yes \\
\hline Newspaper FE & Yes & Yes & Yes & Yes & Yes & Yes \\
\hline Outcome Mean & 43.072 & 10.002 & 7.941 & 39.416 & 9.484 & 3.801 \\
\hline
\end{tabular}

Note: This table shows the impact of private equity buyouts on turnout in local elections. In Panel A, the sample is limited to newspapers that survived to the end of the sample. In Panel B, the sample is further limited to survivor newspapers that also have at least some digital circulation. $* * *$ denotes p-value $<.01$, ** denotes p-value $<.05$, and $*$ denotes $\mathrm{p}$-value $<.1$. 


\section{Table A.8: Private Equity Ownership and Article Content: Survivor \& Digital Newspapers Only}

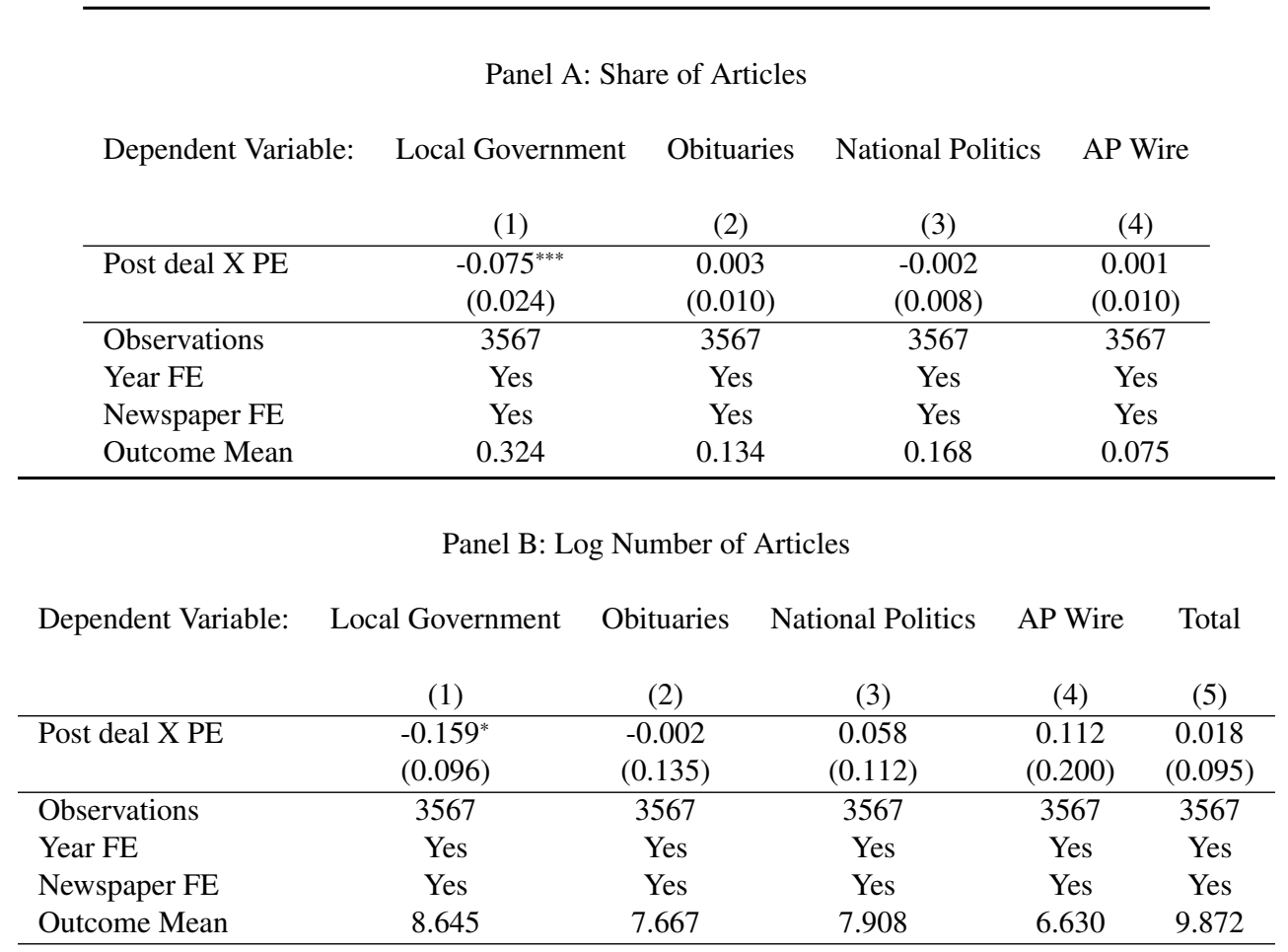

Note: This table shows the impact of private equity buyouts on news content, where the sample is limited to newspapers that have at least some digital circulation and survived to the end of the sample. $* * *$ denotes $\mathrm{p}$-value $<.01$, ** denotes $\mathrm{p}$-value $<.05$, and $*$ denotes p-value $<.1$. 
Table A.9: Private Equity Ownership by Previous Owner Type: Articles

\begin{tabular}{|c|c|c|c|c|}
\hline \multirow[b]{2}{*}{ Dependent Variable: } & \multicolumn{3}{|c|}{ Panel A: Share of Articles } & \multirow{3}{*}{$\begin{array}{c}\text { AP Wire } \\
\text { (4) }\end{array}$} \\
\hline & Local Government & Obituaries & National Politics & \\
\hline & (1) & (2) & (3) & \\
\hline \multirow[t]{2}{*}{ Post deal X PE (from Family) } & -0.013 & -0.004 & 0.009 & $-0.027^{* * *}$ \\
\hline & $(0.020)$ & $(0.009)$ & $(0.009)$ & $(0.010)$ \\
\hline \multirow[t]{2}{*}{ Post deal X PE (from Other Fin) } & 0.036 & $-0.055^{* *}$ & $0.053^{* * *}$ & 0.018 \\
\hline & $(0.051)$ & $(0.025)$ & $(0.019)$ & $(0.015)$ \\
\hline \multirow[t]{2}{*}{ Post deal X PE (from Public) } & $-0.070^{* *}$ & $0.034^{* *}$ & -0.008 & -0.012 \\
\hline & $(0.028)$ & $(0.017)$ & $(0.010)$ & $(0.013)$ \\
\hline \multirow[t]{2}{*}{ Post deal X PE (from Priv Chain) } & -0.003 & $-0.022^{*}$ & 0.014 & 0.008 \\
\hline & $(0.031)$ & $(0.013)$ & $(0.012)$ & $(0.010)$ \\
\hline \multirow[t]{2}{*}{ Post deal X PE (from Independent) } & 0.024 & -0.027 & -0.018 & 0.010 \\
\hline & $(0.039)$ & $(0.018)$ & $(0.018)$ & $(0.020)$ \\
\hline Observations & 10952 & 10952 & 10952 & 10952 \\
\hline Year FE & Yes & Yes & Yes & Yes \\
\hline Newspaper FE & Yes & Yes & Yes & Yes \\
\hline Outcome Mean & 0.332 & 0.139 & 0.157 & 0.050 \\
\hline
\end{tabular}

Panel B: Log Number of Articles

\begin{tabular}{lccccc} 
Dependent Variable: & Local Government & Obituaries & National Politics & AP Wire & Total \\
& & & & & $(5)$ \\
& $(1)$ & $(2)$ & $(3)$ & $(4)$ & $(5)$ \\
\hline Post deal X PE (from Family) & $-0.247^{* * *}$ & $-0.314^{* * *}$ & -0.178 & $-0.562^{* * *}$ & $-0.222^{* * *}$ \\
& $(0.078)$ & $(0.110)$ & $(0.119)$ & $(0.193)$ & $(0.080)$ \\
Post deal X PE (from Other Fin) & 0.120 & -0.317 & 0.417 & 0.385 & 0.038 \\
& $(0.231)$ & $(0.262)$ & $(0.263)$ & $(0.359)$ & $(0.216)$ \\
Post deal X PE (from Public) & $-0.282^{* *}$ & 0.005 & -0.214 & -0.364 & -0.103 \\
& $(0.135)$ & $(0.188)$ & $(0.184)$ & $(0.307)$ & $(0.146)$ \\
Post deal X PE (from Priv Chain) & -0.144 & $-0.356^{* * *}$ & -0.081 & 0.052 & $-0.155^{*}$ \\
& $(0.099)$ & $(0.137)$ & $(0.138)$ & $(0.203)$ & $(0.084)$ \\
Post deal X PE (from Independent) & 0.031 & $-0.300^{*}$ & -0.274 & 0.050 & -0.084 \\
& $(0.105)$ & $(0.180)$ & $(0.211)$ & $(0.345)$ & $(0.131)$ \\
\hline Observations & 10952 & 10952 & 10952 & 10952 & 10952 \\
Year FE & Yes & Yes & Yes & Yes & Yes \\
Newspaper FE & Yes & Yes & Yes & Yes & Yes \\
Outcome Mean & 7.895 & 6.930 & 6.972 & 5.274 & 9.122 \\
\hline
\end{tabular}

Note: This table shows the impact of private equity buyouts on article content by previous ownership type. The model estimates the impact of private equity ownership separately for each previous ownership type that appears in the data. Content topic areas are defined above. $* * *$ denotes p-value $<.01, * *$ denotes p-value $<.05$, and $*$ denotes p-value $<.1$. 


\section{Table A.10: Private Equity Ownership by Previous Owner Type: Employment}

\begin{tabular}{|c|c|c|c|c|}
\hline Dependent Variable: & Reporters & Editors & $\begin{array}{c}\text { Interns \& } \\
\text { Freelancers }\end{array}$ & Employees \\
\hline & (1) & (2) & (3) & (4) \\
\hline Post deal X PE (from Family) & $\begin{array}{l}-0.017 \\
(0.059)\end{array}$ & $\begin{array}{c}0.041 \\
(0.053)\end{array}$ & $\begin{array}{c}0.100 \\
(0.068)\end{array}$ & $\begin{array}{c}0.059 \\
(0.061)\end{array}$ \\
\hline Post deal X PE (from Other Fin) & $\begin{array}{c}0.115 \\
(0.107)\end{array}$ & $\begin{array}{c}0.089 \\
(0.072)\end{array}$ & $\begin{array}{l}-0.006 \\
(0.111)\end{array}$ & $\begin{array}{c}0.123 \\
(0.100)\end{array}$ \\
\hline Post deal X PE (from Public) & $\begin{array}{l}-0.123 \\
(0.090)\end{array}$ & $\begin{array}{c}-0.179^{* *} \\
(0.087)\end{array}$ & $\begin{array}{c}0.127 \\
(0.079)\end{array}$ & $\begin{array}{l}-0.110 \\
(0.082)\end{array}$ \\
\hline Post deal X PE (from Priv Chain) & $\begin{array}{l}-0.061 \\
(0.062)\end{array}$ & $\begin{array}{c}-0.155^{* * *} \\
(0.044)\end{array}$ & $\begin{array}{c}-0.140^{* *} \\
(0.057)\end{array}$ & $\begin{array}{c}-0.143^{* * *} \\
(0.051)\end{array}$ \\
\hline Post deal X PE (from Independent) & $\begin{array}{l}-0.074 \\
(0.101)\end{array}$ & $\begin{array}{c}0.051 \\
(0.145)\end{array}$ & $\begin{array}{c}0.154 \\
(0.150)\end{array}$ & $\begin{array}{c}0.085 \\
(0.117)\end{array}$ \\
\hline Observations & 12641 & 12641 & 12641 & 12641 \\
\hline$R^{2}$ & 0.093 & 0.047 & 0.133 & 0.183 \\
\hline Year FE & Yes & Yes & Yes & Yes \\
\hline Newspaper FE & Yes & Yes & Yes & Yes \\
\hline Outcome Mean & 1.188 & 1.717 & 0.518 & 2.531 \\
\hline
\end{tabular}

Note: This table shows the impact of private equity buyouts on employees by previous ownership type. The model estimates the impact of private equity ownership separately for each previous ownership type that appears in the data. Employee variables are defined above. $* * *$ denotes p-value $<.01, * *$ denotes p-value $<.05$, and $*$ denotes p-value $<.1$. 
Table A.11: Private Equity Ownership by Previous Owner Type: Operations

\begin{tabular}{|c|c|c|c|c|c|c|}
\hline \multirow{3}{*}{ Dependent Variable: } & \multicolumn{6}{|c|}{ Panel A: Circulation \& Advertising } \\
\hline & \multicolumn{4}{|c|}{ Circulation } & \multicolumn{2}{|c|}{ Advertising Rate } \\
\hline & $\begin{array}{l}\text { No Stale } \\
\text { (1) }\end{array}$ & $\begin{array}{l}\text { All } \\
(2)\end{array}$ & $\begin{array}{l}\text { Digital } \\
\text { (3) }\end{array}$ & $\begin{array}{l}\text { All } \\
(4)\end{array}$ & $\begin{array}{c}\text { No Stale } \\
\text { (5) }\end{array}$ & $\begin{array}{l}\text { All } \\
(6)\end{array}$ \\
\hline Post deal X PE (from Family) & $\begin{array}{c}-0.076^{* * *} \\
(0.027)\end{array}$ & $\begin{array}{c}-0.085^{* * *} \\
(0.030)\end{array}$ & $\begin{array}{l}-0.230 \\
(0.412)\end{array}$ & $\begin{array}{c}-0.051 \\
(0.043)\end{array}$ & $\begin{array}{l}-0.039 \\
(0.056)\end{array}$ & $\begin{array}{l}-0.063 \\
(0.040)\end{array}$ \\
\hline Post deal X PE (from Other Fin) & $\begin{array}{c}0.171^{* * *} \\
(0.052)\end{array}$ & $\begin{array}{c}0.201^{* * *} \\
(0.048)\end{array}$ & $\begin{array}{c}-5.001^{* * *} \\
(0.215)\end{array}$ & $\begin{array}{c}0.029 \\
(0.024)\end{array}$ & $\begin{array}{l}-0.086 \\
(0.073)\end{array}$ & $\begin{array}{l}-0.063 \\
(0.051)\end{array}$ \\
\hline Post deal X PE (from Public) & $\begin{array}{c}-0.121^{* * *} \\
(0.030)\end{array}$ & $\begin{array}{c}-0.297^{* * *} \\
(0.031)\end{array}$ & $\begin{array}{c}0.132 \\
(0.203)\end{array}$ & $\begin{array}{c}-0.094^{* * *} \\
(0.025)\end{array}$ & $\begin{array}{l}-0.048 \\
(0.052)\end{array}$ & $\begin{array}{l}-0.046 \\
(0.040)\end{array}$ \\
\hline Post deal X PE (from Priv Chain) & $\begin{array}{c}-0.063^{* *} \\
(0.028)\end{array}$ & $\begin{array}{l}-0.004 \\
(0.037)\end{array}$ & $\begin{array}{l}1.877^{* * *} \\
(0.415)\end{array}$ & $\begin{array}{c}-0.005 \\
(0.026)\end{array}$ & $\begin{array}{c}0.028 \\
(0.056)\end{array}$ & $\begin{array}{c}0.055 \\
(0.047)\end{array}$ \\
\hline Post deal X PE (from Independent) & $\begin{array}{c}0.093 \\
(0.057)\end{array}$ & $\begin{array}{l}0.098^{* *} \\
(0.045)\end{array}$ & $\begin{array}{c}0.509 \\
(0.440)\end{array}$ & $\begin{array}{c}-0.003 \\
(0.041)\end{array}$ & $\begin{array}{c}0.066 \\
(0.072)\end{array}$ & $\begin{array}{l}-0.005 \\
(0.050)\end{array}$ \\
\hline Observations & 15039 & 22792 & 3292 & 3419 & 10549 & 22192 \\
\hline$R^{2}$ & 0.595 & 0.431 & 0.113 & 0.755 & 0.093 & 0.088 \\
\hline Year FE & Yes & Yes & Yes & Yes & Yes & Yes \\
\hline Newspaper FE & Yes & Yes & Yes & Yes & Yes & Yes \\
\hline Outcome Mean & 9.775 & 9.427 & 5.033 & 10.101 & 3.200 & 3.183 \\
\hline
\end{tabular}

Panel B: Closure or Change of Status

\begin{tabular}{lcccc} 
Dependent Variable: & Any Closure & Shut Down & Merged \& New Name & Became Weekly \\
& $(1)$ & $(2)$ & $(3)$ & $(4)$ \\
\hline Post deal X PE (from Family) & $-0.007^{* *}$ & $-0.002^{* *}$ & -0.000 & -0.004 \\
& $(0.003)$ & $(0.001)$ & $(0.002)$ & $(0.002)$ \\
Post deal X PE (from Other Fin) & 0.001 & -0.002 & -0.002 & 0.005 \\
& $(0.006)$ & $(0.002)$ & $(0.002)$ & $(0.005)$ \\
Post deal X PE (from Public) & $-0.012^{* * *}$ & $-0.003^{* * *}$ & -0.001 & $-0.008^{* * *}$ \\
& $(0.004)$ & $(0.001)$ & $(0.003)$ & $(0.002)$ \\
Post deal X PE (from Priv Chain) & -0.000 & -0.001 & -0.001 & 0.001 \\
& $(0.003)$ & $(0.001)$ & $(0.002)$ & $(0.002)$ \\
Post deal X PE (from Independent) & $-0.011^{* * *}$ & -0.002 & $-0.002^{* *}$ & $-0.008^{* * *}$ \\
& $(0.003)$ & $(0.001)$ & $(0.001)$ & $(0.002)$ \\
\hline Observations & 26720 & 26736 & 26730 & 26730 \\
$R^{2}$ & 0.024 & 0.008 & 0.008 & 0.016 \\
Year FE & Yes & Yes & Yes & Yes \\
State FE & Yes & Yes & Yes & Yes \\
Outcome Mean & 0.011 & 0.004 & 0.003 & 0.005 \\
\hline
\end{tabular}

Note: This table shows the impact of private equity buyouts on operations by previous ownership type. The model estimates the impact of private equity ownership separately for each previous ownership type that appears in the data. Operation variables are defined above. $* * *$ denotes $\mathrm{p}$-value $<.01$, ** denotes $\mathrm{p}$-value $<.05$, and $*$ denotes $\mathrm{p}$-value $<.1$. 
Table A.12: Private Equity Ownership by Previous Owner Type: Political Outcomes

\begin{tabular}{|c|c|c|c|c|c|c|}
\hline \multirow{3}{*}{$\begin{array}{l}\text { Election Type: } \\
\text { Dependent Variable: }\end{array}$} & \multicolumn{3}{|c|}{ Panel A: Local Election Participation } & & & \\
\hline & \multicolumn{3}{|c|}{ County Council } & \multicolumn{3}{|c|}{ Mayor } \\
\hline & Total Votes & $\begin{array}{l}\text { Log Total } \\
\text { Votes }\end{array}$ & Turnout (\%) & Total Votes & $\begin{array}{l}\text { Log Total } \\
\text { Votes }\end{array}$ & Turnout $(\%)$ \\
\hline & (1) & (2) & (3) & (4) & (5) & (6) \\
\hline Post deal X PE (from Family) & $\begin{array}{c}0.178 \\
(2.111)\end{array}$ & $\begin{array}{l}-0.028 \\
(0.132)\end{array}$ & $\begin{array}{l}-0.118 \\
(0.454)\end{array}$ & $\begin{array}{l}-2.124 \\
(4.577)\end{array}$ & $\begin{array}{c}0.011 \\
(0.153)\end{array}$ & $\begin{array}{l}-0.044 \\
(0.392)\end{array}$ \\
\hline Post deal X PE (from Other Fin) & $\begin{array}{l}-3.040 \\
(3.747)\end{array}$ & $\begin{array}{c}0.009 \\
(0.138)\end{array}$ & $\begin{array}{c}0.156 \\
(0.680)\end{array}$ & $\begin{array}{c}-5.839 \\
(11.450)\end{array}$ & $\begin{array}{l}-0.135 \\
(0.227)\end{array}$ & $\begin{array}{c}0.298 \\
(0.548)\end{array}$ \\
\hline Post deal X PE (from Public) & $\begin{array}{l}-0.110 \\
(3.733)\end{array}$ & $\begin{array}{l}-0.132 \\
(0.134)\end{array}$ & $\begin{array}{l}-0.571 \\
(0.658)\end{array}$ & $\begin{array}{c}1.548 \\
(11.560)\end{array}$ & $\begin{array}{l}-0.066 \\
(0.231)\end{array}$ & $\begin{array}{l}-0.440 \\
(0.585)\end{array}$ \\
\hline Post deal X PE (from Priv Chain) & $\begin{array}{l}-2.456 \\
(2.327)\end{array}$ & $\begin{array}{l}-0.086 \\
(0.148)\end{array}$ & $\begin{array}{l}-1.032 \\
(0.813)\end{array}$ & $\begin{array}{l}-4.750 \\
(5.546)\end{array}$ & $\begin{array}{c}-0.297^{* *} \\
(0.142)\end{array}$ & $\begin{array}{c}-0.024 \\
(0.447)\end{array}$ \\
\hline Post deal X PE (from Independent) & $\begin{array}{l}-6.980^{*} \\
(3.965)\end{array}$ & $\begin{array}{l}-0.143 \\
(0.174)\end{array}$ & $\begin{array}{c}0.759 \\
(0.968)\end{array}$ & $\begin{array}{c}20.333 \\
(14.597)\end{array}$ & $\begin{array}{c}0.380 \\
(0.354)\end{array}$ & $\begin{array}{c}0.678 \\
(0.909)\end{array}$ \\
\hline Observations & 2124 & 2124 & 2122 & 1960 & 1960 & 1960 \\
\hline$R^{2}$ & 0.299 & 0.197 & 0.076 & 0.156 & 0.084 & 0.034 \\
\hline Year FE & Yes & Yes & Yes & Yes & Yes & Yes \\
\hline Newspaper FE & Yes & Yes & Yes & Yes & Yes & Yes \\
\hline Outcome Mean & 32.283 & 9.492 & 8.745 & 26.111 & 8.848 & 4.637 \\
\hline
\end{tabular}

Note: This table shows the impact of private equity buyouts on political outcomes by previous ownership type. The model estimates the impact of private equity ownership separately for each previous ownership type that appears in the data. Political outcome variables are defined above. $* * *$ denotes p-value $<.01$, $* *$ denotes p-value $<.05$, and $*$ denotes p-value $<.1$. 


\section{Table A.13: Alternate Control Groups}

\begin{tabular}{lcccc}
\hline \multicolumn{5}{c}{ Panel A: Share of Articles } \\
Control Group: & Independent & Family & Private Chain & Public Company \\
& & & & \\
& $(1)$ & $(2)$ & $(3)$ & $(4)$ \\
\hline Post deal X PE & $-0.045^{* *}$ & -0.018 & -0.003 & $-0.111^{* *}$ \\
& $(0.018)$ & $(0.025)$ & $(0.034)$ & $(0.054)$ \\
\hline Observations & 371 & 1561 & 670 & 518 \\
Year FE & Yes & Yes & Yes & Yes \\
Newspaper FE & Yes & Yes & Yes & Yes \\
Outcome Mean & 0.331 & 0.320 & 0.296 & 0.315 \\
\hline
\end{tabular}

Panel B: Log Number of Articles

Control Group: Independent Family Private Chain Public Company

\begin{tabular}{lcccc} 
& $(1)$ & $(2)$ & $(3)$ & $(4)$ \\
\hline Post deal X PE & 0.053 & -0.108 & -0.150 & -0.251 \\
& $(0.127)$ & $(0.097)$ & $(0.117)$ & $(0.176)$ \\
\hline Observations & 371 & 1561 & 670 & 518 \\
Year FE & Yes & Yes & Yes & Yes \\
Newspaper FE & Yes & Yes & Yes & Yes \\
Outcome Mean & 8.051 & 8.063 & 7.759 & 8.388 \\
\hline
\end{tabular}

Note: The table repeats the analysis from Table 4 but subsets on each individual category of ownership. The comparison in column (1) subsets on all independently owned newspapers, and compares outcomes for those that stay independently owned relative to those which are purchased by private equity firms. We do the analysis similarly for four main types of ownership. Standard errors are clustered by newspaper. $* * *$ denotes $\mathrm{p}$-value $<.01, * *$ denotes $\mathrm{p}$-value $<.05$, and $*$ denotes $\mathrm{p}$-value $<.1$. 
Table A.14: Staggered Difference-in-Differences Robustness

Panel A: Article Content

Sun and Abraham (2020):

Callaway and Sant'Anna (2020):

\begin{tabular}{|c|c|c|c|c|c|c|c|c|}
\hline \multirow[t]{2}{*}{ Dependent Variable: } & \multicolumn{2}{|c|}{ Share of Articles on } & \multicolumn{2}{|c|}{ Number of Articles on } & \multicolumn{2}{|c|}{ Share of Articles on } & \multicolumn{2}{|c|}{ Number of Articles on } \\
\hline & $\begin{array}{l}\text { Local } \\
\text { (1) }\end{array}$ & $\begin{array}{c}\text { National } \\
\text { (2) }\end{array}$ & $\begin{array}{l}\text { Local } \\
\text { (3) }\end{array}$ & $\begin{array}{c}\text { National } \\
\text { (4) }\end{array}$ & $\begin{array}{l}\text { Local } \\
(5)\end{array}$ & $\begin{array}{l}\text { National } \\
\text { (6) }\end{array}$ & $\begin{array}{l}\text { Local } \\
(7)\end{array}$ & $\begin{array}{c}\text { National } \\
\text { (8) }\end{array}$ \\
\hline Post deal X PE & $\begin{array}{c}-0.065^{* * *} \\
(0.022)\end{array}$ & $\begin{array}{c}0.005 \\
(0.004)\end{array}$ & $\begin{array}{l}-0.059 \\
(0.092)\end{array}$ & $\begin{array}{c}0.165 \\
(0.106)\end{array}$ & $\begin{array}{c}-0.062^{* * *} \\
(0.022)\end{array}$ & $\begin{array}{l}0.005^{* *} \\
(0.002)\end{array}$ & $\begin{array}{l}-0.062 \\
(0.092)\end{array}$ & $\begin{array}{c}0.156 \\
(0.106)\end{array}$ \\
\hline Observations & 10,957 & 10,957 & 10,957 & 10,957 & 10,957 & 10,957 & 10,957 & 10,957 \\
\hline Year FE & Yes & Yes & Yes & Yes & Yes & Yes & Yes & Yes \\
\hline Newspaper FE & Yes & Yes & Yes & Yes & Yes & Yes & Yes & Yes \\
\hline Outcome Mean & 0.332 & 0.157 & 7.895 & 6.972 & 0.332 & 0.157 & 7.895 & 6.972 \\
\hline
\end{tabular}

Panel B: Employees and Operations

Sun and Abraham (2020):

Callaway and Sant'Anna (2020):

\begin{tabular}{|c|c|c|c|c|c|c|c|c|}
\hline \multirow[t]{2}{*}{ Dependent Variable: } & Reporters & Editors & Circ & Circ No Stale & Reporters & Editors & Circ & Circ No Stale \\
\hline & (1) & (2) & (3) & (4) & (5) & (6) & (7) & (8) \\
\hline \multirow[t]{2}{*}{ Post deal X PE } & -0.067 & -0.063 & -0.069 & -0.029 & $-0.069^{*}$ & -0.065 & -0.078 & -0.054 \\
\hline & $(0.042)$ & $(0.043)$ & $(0.091)$ & $(0.102)$ & $(0.042)$ & $(0.043)$ & $(0.092)$ & $(0.103)$ \\
\hline Observations & 12,641 & 12,641 & 22,792 & 15,039 & 12,641 & 12,641 & 22,792 & 15,039 \\
\hline Year FE & Yes & Yes & Yes & Yes & Yes & Yes & Yes & Yes \\
\hline Newspaper FE & Yes & Yes & Yes & Yes & Yes & Yes & Yes & Yes \\
\hline Outcome Mean & 1.188 & 1.279 & 9.427 & 9.775 & 1.188 & 1.279 & 9.427 & 9.775 \\
\hline
\end{tabular}

Note: The table reports two alternative difference-in-difference specifications using the Sun and Abraham (2021) and Callaway and Sant'Anna (2021) estimators. All specifications are otherwise identical to those in Tables $4-6$. $* * *$ denotes p-value $<.01$, ** denotes p-value $<.05$, and $*$ denotes p-value $<.1$. 
Table A.15: Machine Learning Robustness: Local Keywords

\begin{tabular}{|c|c|c|c|c|c|}
\hline \multirow[t]{2}{*}{ Dependent Variable: } & park & district & street & building & schools \\
\hline & (1) & (2) & (3) & (4) & (5) \\
\hline \multirow[t]{2}{*}{ Post deal X PE } & $-0.154^{*}$ & $-0.172^{* *}$ & $-0.177^{* *}$ & $-0.179^{* *}$ & $-0.168^{* *}$ \\
\hline & $(0.082)$ & $(0.068)$ & $(0.086)$ & $(0.075)$ & $(0.079)$ \\
\hline Observations & 5871 & 5872 & 5874 & 5871 & 5867 \\
\hline Year FE & Yes & Yes & Yes & Yes & Yes \\
\hline Newspaper FE & Yes & Yes & Yes & Yes & Yes \\
\hline Outcome Mean & 6.702 & 6.828 & 6.776 & 6.685 & 6.479 \\
\hline \multirow[t]{2}{*}{ Dependent Variable: } & fire & community & officers & board & students \\
\hline & (6) & (7) & (8) & (9) & (10) \\
\hline \multirow[t]{2}{*}{ Post deal X PE } & $-0.221^{* * *}$ & $-0.172^{* *}$ & $-0.264^{* * *}$ & -0.098 & $-0.187^{* *}$ \\
\hline & $(0.082)$ & $(0.078)$ & $(0.082)$ & $(0.102)$ & $(0.087)$ \\
\hline Observations & 5870 & 5873 & 5863 & 5873 & 5869 \\
\hline Year FE & Yes & Yes & Yes & Yes & Yes \\
\hline Newspaper FE & Yes & Yes & Yes & Yes & Yes \\
\hline Outcome Mean & 6.422 & 7.185 & 5.901 & 6.826 & 6.673 \\
\hline \multirow[t]{2}{*}{ Dependent Variable: } & church & hospital & judge & neighborhood & union \\
\hline & $(11)$ & (12) & (13) & (14) & (15) \\
\hline \multirow[t]{2}{*}{ Post deal X PE } & $-0.173^{*}$ & $-0.179^{*}$ & $-0.288^{* * *}$ & $-0.268^{* * *}$ & -0.139 \\
\hline & $(0.094)$ & $(0.102)$ & $(0.084)$ & $(0.095)$ & $(0.103)$ \\
\hline Observations & 5869 & 5868 & 5862 & 5864 & 5864 \\
\hline Year FE & Yes & Yes & Yes & Yes & Yes \\
\hline Newspaper FE & Yes & Yes & Yes & Yes & Yes \\
\hline Outcome Mean & 6.802 & 6.479 & 5.872 & 5.162 & 5.829 \\
\hline
\end{tabular}

Note: The table repeats the analysis from Table 4 with a different set of keywords designed to measure local news content. We use a tf-idf Machine Learning approach, and report the results separately for each of the words identified by the exercise. Local keywords are identified as the words most commonly found in the local sections relative to the national section of two newspapers (Boston Globe and Chicago Tribune) for which we have full-text information. Standard errors are clustered by newspaper. $* * *$ denotes $\mathrm{p}$-value $<.01$, ** denotes p-value $<.05$, and $*$ denotes $\mathrm{p}$-value $<.1$. 
Table A.16: Machine Learning Robustness: National Keywords

\begin{tabular}{|c|c|c|c|c|c|}
\hline \multirow[t]{2}{*}{ Dependent Variable: } & administration & bush & campaign & edwards & hussein \\
\hline & (1) & (2) & (3) & (4) & (5) \\
\hline \multirow[t]{2}{*}{ Post deal X PE } & $-0.226^{* *}$ & $-0.246^{*}$ & -0.149 & $-0.188^{*}$ & -0.103 \\
\hline & $(0.107)$ & $(0.136)$ & $(0.108)$ & $(0.097)$ & $(0.143)$ \\
\hline Observations & 5863 & 5858 & 5865 & 5845 & 5181 \\
\hline Year FE & Yes & Yes & Yes & Yes & Yes \\
\hline Newspaper FE & Yes & Yes & Yes & Yes & Yes \\
\hline Outcome Mean & 5.916 & 5.026 & 5.795 & 4.579 & 2.504 \\
\hline \multirow[t]{2}{*}{ Dependent Variable: } & iraq & soldiers & troops & voters & war \\
\hline & (6) & (7) & (8) & (9) & $(10)$ \\
\hline \multirow[t]{2}{*}{ Post deal X PE } & -0.113 & -0.134 & -0.079 & $-0.212^{* *}$ & $-0.201^{* *}$ \\
\hline & $(0.147)$ & $(0.114)$ & $(0.132)$ & $(0.094)$ & $(0.099)$ \\
\hline Observations & 5822 & 5849 & 5847 & 5864 & 5869 \\
\hline Year FE & Yes & Yes & Yes & Yes & Yes \\
\hline Newspaper FE & Yes & Yes & Yes & Yes & Yes \\
\hline Outcome Mean & 4.526 & 4.465 & 4.316 & 5.465 & 6.145 \\
\hline \multirow[t]{2}{*}{ Dependent Variable: } & attacks & weapons & democrats & baghdad & forces \\
\hline & (11) & (12) & (13) & (14) & (15) \\
\hline \multirow[t]{2}{*}{ Post deal X PE } & -0.204 & $-0.215^{*}$ & -0.199 & -0.056 & $-0.225^{*}$ \\
\hline & $(0.139)$ & $(0.119)$ & $(0.130)$ & $(0.161)$ & $(0.129)$ \\
\hline Observations & 5845 & 5852 & 5829 & 5130 & 5853 \\
\hline Year FE & Yes & Yes & Yes & Yes & Yes \\
\hline b Newspaper FE & Yes & Yes & Yes & Yes & Yes \\
\hline Outcome Mean & 4.567 & 4.548 & 4.880 & 2.475 & 4.857 \\
\hline
\end{tabular}

Note: The table repeats the analysis from Table 4 with a different set of keywords designed to measure national news content. We use a tf-idf Machine Learning approach, and report the results separately for each of the words identified by the exercise. Local keywords are identified as the words most commonly found in the national sections relative to the local section of two newspapers (Boston Globe and Chicago Tribune) for which we have full-text information. Standard errors are clustered by newspaper. $* * *$ denotes p-value $<.01$, ** denotes p-value $<.05$, and $*$ denotes p-value $<.1$. 
Table A.17: Private Equity Ownership Leave-One-Out Robustness for Article Content: Local Government

Panel A: Share of Articles

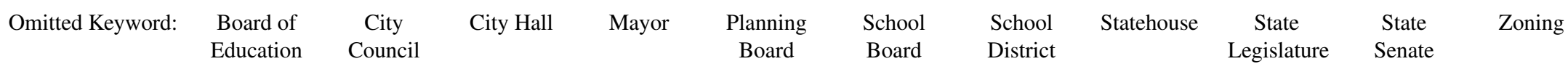

Education Council Board Board District Segislature Senate

\begin{tabular}{|c|c|c|c|c|c|c|c|c|c|c|c|}
\hline & (1) & (2) & (3) & (4) & $(5)$ & $(6)$ & (7) & $(8)$ & (9) & $(10)$ & (11) \\
\hline Post Deal $\times$ PE & $\begin{array}{c}-0.033^{* *} \\
(0.015)\end{array}$ & $\begin{array}{c}-0.034^{* *} \\
(0.014)\end{array}$ & $\begin{array}{c}-0.033^{* *} \\
(0.015)\end{array}$ & $\begin{array}{c}-0.035^{* *} \\
(0.014)\end{array}$ & $\begin{array}{c}-0.033^{* *} \\
(0.015)\end{array}$ & $\begin{array}{c}-0.033^{* *} \\
(0.015)\end{array}$ & $\begin{array}{c}-0.034^{* *} \\
(0.014)\end{array}$ & $\begin{array}{c}-0.033^{* *} \\
(0.015)\end{array}$ & $\begin{array}{c}-0.033^{* *} \\
(0.015)\end{array}$ & $\begin{array}{c}-0.033^{* *} \\
(0.015)\end{array}$ & $\begin{array}{c}-0.032^{* *} \\
(0.015)\end{array}$ \\
\hline Observations & 10952 & 10952 & 10952 & 10952 & 10952 & 10952 & 10952 & 10952 & 10952 & 10952 & 10952 \\
\hline Year FE & Yes & Yes & Yes & Yes & Yes & Yes & Yes & Yes & Yes & Yes & Yes \\
\hline Newspaper FE & Yes & Yes & Yes & Yes & Yes & Yes & Yes & Yes & Yes & Yes & Yes \\
\hline Outcome Mean & 0.372 & 0.353 & 0.368 & 0.343 & 0.378 & 0.378 & 0.356 & 0.376 & 0.377 & 0.377 & 0.371 \\
\hline
\end{tabular}

Panel B: Log Number of Articles

Omitted Keyword: $\quad$ Board of City City Hall Mayor Planning School $\quad$ School Statehouse State $\quad$ State $\quad$ Zoning

$\bowtie$

Education Council Board Board District $\quad$ Legislature Senate

\begin{tabular}{|c|c|c|c|c|c|c|c|c|c|c|c|}
\hline & (1) & (2) & (3) & (4) & (5) & (6) & (7) & (8) & (9) & (10) & (11) \\
\hline Post Deal $\times$ PE & $\begin{array}{c}-0.240^{* * *} \\
(0.053)\end{array}$ & $\begin{array}{c}-0.243^{\text {*** }} \\
(0.054)\end{array}$ & $\begin{array}{c}-0.239^{* * *} \\
(0.053)\end{array}$ & $\begin{array}{c}-0.247^{\text {*** }} \\
(0.054)\end{array}$ & $\begin{array}{c}-0.238^{* * *} \\
(0.052)\end{array}$ & $\begin{array}{c}-0.238^{* * *} \\
(0.052)\end{array}$ & $\begin{array}{c}-0.246^{\text {*** }} \\
(0.053)\end{array}$ & $\begin{array}{c}-0.239^{* * *} \\
(0.052)\end{array}$ & $\begin{array}{c}-0.239^{* * *} \\
(0.052)\end{array}$ & $\begin{array}{c}-0.239^{* * *} \\
(0.052)\end{array}$ & $\begin{array}{c}-0.236^{* * *} \\
(0.053)\end{array}$ \\
\hline Observations & 10952 & 10952 & 10952 & 10952 & 10952 & 10952 & 10952 & 10952 & 10952 & 10952 & 10952 \\
\hline Year FE & Yes & Yes & Yes & Yes & Yes & Yes & Yes & Yes & Yes & Yes & Yes \\
\hline Newspaper FE & Yes & Yes & Yes & Yes & Yes & Yes & Yes & Yes & Yes & Yes & Yes \\
\hline Outcome Mean & 8.023 & 7.970 & 8.012 & 7.934 & 8.044 & 8.044 & 7.975 & 8.036 & 8.038 & 8.039 & 8.023 \\
\hline
\end{tabular}

Note: This table shows the impact of private equity buyouts on the single outcomes of local government news content, where each model leaves out one of the keywords used to construct the measure of local content. *** denotes p-value $<.01, * *$ denotes $\mathrm{p}$-value $<.05$, and $*$ denotes $\mathrm{p}$-value $<.1$. 
Table A.18: Private Equity Ownership Leave-One-Out Robustness for Article Content: National Government

Panel A: Share of Articles

\begin{tabular}{|c|c|c|c|c|c|c|c|}
\hline \multirow[t]{2}{*}{ Omitted Keyword: } & Bush & Congress & Obama & Trump & $\begin{array}{l}\text { White } \\
\text { House }\end{array}$ & Democrat & Republican \\
\hline & (1) & $(2)$ & (3) & (4) & (5) & (6) & (7) \\
\hline \multirow[t]{2}{*}{ Post Deal $\times$ PE } & $0.012^{*}$ & $0.011^{* *}$ & $0.012^{* *}$ & $0.009^{*}$ & $0.012^{* *}$ & $0.014^{* *}$ & $0.009^{*}$ \\
\hline & $(0.006)$ & $(0.006)$ & $(0.006)$ & $(0.006)$ & $(0.006)$ & $(0.006)$ & $(0.005)$ \\
\hline Observations & 10952 & 10952 & 10952 & 10952 & 10952 & 10952 & 10952 \\
\hline Year FE & Yes & Yes & Yes & Yes & Yes & Yes & Yes \\
\hline Newspaper FE & Yes & Yes & Yes & Yes & Yes & Yes & Yes \\
\hline \multirow[t]{2}{*}{ Outcome Mean } & 0.138 & 0.135 & 0.139 & 0.144 & 0.147 & 0.124 & 0.120 \\
\hline & \multicolumn{6}{|c|}{ Panel B: Log Number of Articles } & \\
\hline \multirow[t]{2}{*}{ Omitted Keyword: } & Bush & Congress & Obama & Trump & $\begin{array}{l}\text { White } \\
\text { House }\end{array}$ & Democrat & Republican \\
\hline & $(1)$ & $(2)$ & $(3)$ & (4) & $(5)$ & (6) & $(7)$ \\
\hline \multirow[t]{2}{*}{ Post Deal $\times$ PE } & -0.121 & -0.121 & -0.124 & -0.125 & -0.120 & -0.106 & -0.132 \\
\hline & $(0.082)$ & $(0.081)$ & $(0.080)$ & $(0.080)$ & $(0.079)$ & $(0.084)$ & $(0.084)$ \\
\hline Observations & 10952 & 10952 & 10952 & 10952 & 10952 & 10952 & 10952 \\
\hline Year FE & Yes & Yes & Yes & Yes & Yes & Yes & Yes \\
\hline Newspaper FE & Yes & Yes & Yes & Yes & Yes & Yes & Yes \\
\hline Outcome Mean & 6.782 & 6.772 & 6.823 & 6.882 & 6.894 & 6.803 & 6.673 \\
\hline
\end{tabular}

Note: This table shows the impact of private equity buyouts on the single outcomes of national government news content, where each model leaves out one of the keywords used to construct the measure of national content. $* * *$ denotes p-value $<.01$, $* *$ denotes $\mathrm{p}$-value $<.05$, and $*$ denotes $\mathrm{p}$-value $<.1$. 
Table A.19: Private Equity Ownership Leave-One-Out Robustness for Article Content: Obituary

Panel A: Share of Articles

\begin{tabular}{|c|c|c|c|}
\hline \multirow[t]{2}{*}{ Omitted Keyword: } & Died & $\begin{array}{c}\text { Finally at } \\
\text { Peace }\end{array}$ & $\begin{array}{c}\text { Passed } \\
\text { Away }\end{array}$ \\
\hline & (1) & (2) & (3) \\
\hline \multirow[t]{2}{*}{ Post Deal $\times$ PE } & -0.006 & $-0.013^{*}$ & -0.007 \\
\hline & $(0.004)$ & $(0.007)$ & $(0.006)$ \\
\hline Observations & 10952 & 10952 & 10952 \\
\hline Year FE & Yes & Yes & Yes \\
\hline Newspaper FE & Yes & Yes & Yes \\
\hline Outcome Mean & 0.041 & 0.139 & 0.099 \\
\hline \multicolumn{4}{|c|}{ Panel B: Log Number of Articles } \\
\hline \multirow[t]{2}{*}{ Omitted Keyword: } & Died & $\begin{array}{l}\text { Finally at } \\
\text { Peace }\end{array}$ & $\begin{array}{c}\text { Passed } \\
\text { Away }\end{array}$ \\
\hline & (1) & (2) & (3) \\
\hline \multirow[t]{2}{*}{ Post Deal $\times$ PE } & $-0.425^{* * *}$ & $-0.345^{* * *}$ & $-0.298^{* * *}$ \\
\hline & $(0.134)$ & $(0.081)$ & $(0.080)$ \\
\hline Observations & 10952 & 10952 & 10952 \\
\hline Year FE & Yes & Yes & Yes \\
\hline Newspaper FE & Yes & Yes & Yes \\
\hline Outcome Mean & 5.097 & 6.930 & 6.575 \\
\hline
\end{tabular}

Note: This table shows the impact of private equity buyouts on the single outcomes of national government news content, where each model leaves out one of the keywords used to construct the measure of national content. $* * *$ denotes p-value $<.01$, $* *$ denotes $\mathrm{p}$-value $<.05$, and $*$ denotes $\mathrm{p}$-value $<.1$. 


\section{Table A.20: Main Results with Deal Fixed Effects}

\begin{tabular}{|c|c|c|c|c|}
\hline \multirow{3}{*}{ Dependent Variable: } & \multicolumn{4}{|c|}{ Panel A: Article Content } \\
\hline & \multicolumn{2}{|c|}{ Share of Articles on } & \multicolumn{2}{|c|}{ Number of Articles on } \\
\hline & $\begin{array}{l}\text { Local } \\
\text { (1) }\end{array}$ & $\begin{array}{c}\text { National } \\
\text { (2) }\end{array}$ & $\begin{array}{l}\text { Local } \\
\text { (3) }\end{array}$ & $\begin{array}{c}\text { National } \\
\text { (4) }\end{array}$ \\
\hline Post deal X PE & $\begin{array}{c}-0.030^{* *} \\
(0.014)\end{array}$ & $\begin{array}{l}0.013^{* *} \\
(0.007)\end{array}$ & $\begin{array}{c}-0.226^{* * *} \\
(0.053)\end{array}$ & $\begin{array}{l}-0.120 \\
(0.082)\end{array}$ \\
\hline Observations & 10952 & 10952 & 10952 & 10952 \\
\hline Year FE & Yes & Yes & Yes & Yes \\
\hline Newspaper FE & Yes & Yes & Yes & Yes \\
\hline Deal FE & Yes & Yes & Yes & Yes \\
\hline Outcome Mean & 0.380 & 0.157 & 8.046 & 6.972 \\
\hline
\end{tabular}

Panel B: Employees and Operations

\begin{tabular}{lccccc} 
Dependent Variable: & Reporters & Editors & Closed & Print Circ & Digital Circ \\
& $(1)$ & $(2)$ & $(3)$ & $(4)$ & $(5)$ \\
\hline Post deal X PE & $-0.077^{*}$ & $-0.094^{* * *}$ & $-0.114^{* * *}$ & $-0.006^{* * *}$ & $0.379^{*}$ \\
& $(0.040)$ & $(0.035)$ & $(0.019)$ & $(0.002)$ & $(0.207)$ \\
\hline Observations & 12633 & 12633 & 22767 & 26707 & 3250 \\
Year FE & Yes & Yes & Yes & Yes & Yes \\
Newspaper FE & Yes & Yes & Yes & Yes & Yes \\
Deal FE & Yes & Yes & Yes & Yes & Yes \\
Outcome Mean & 2.531 & 1.188 & 9.428 & 1.226 & 5.084 \\
\hline
\end{tabular}

Panel C: Local Election Participation

\begin{tabular}{lccccc} 
Election Type: & \multicolumn{2}{c}{ County Council } & & \multicolumn{2}{c}{ Mayor } \\
\cline { 2 - 3 } \cline { 5 - 6 } Dependent Variable: & Total Votes & Turnout $(\%)$ & & Total Votes & Turnout $(\%)$ \\
& $(1)$ & $(2)$ & & $(3)$ & $(4)$ \\
\hline Post deal X PE & $-2.956^{*}$ & $-0.805^{* *}$ & & -1.640 & -0.214 \\
& $(1.729)$ & $(0.402)$ & & $(4.107)$ & $(0.295)$ \\
\hline Observations & 2124 & 2122 & & 1960 & 1960 \\
$R^{2}$ & 0.299 & 0.077 & & 0.155 & 0.035 \\
Year FE & Yes & Yes & & Yes & Yes \\
Newspaper FE & Yes & Yes & & Yes & Yes \\
Deal FE & Yes & Yes & & Yes & Yes \\
Outcome Mean & 32.283 & 8.745 & & 26.111 & 4.637 \\
\hline
\end{tabular}

Note: This table shows the main results but including private equity deal fixed effects. Otherwise, models are as described in the main tables. Standard errors are clustered by newspaper. $* * *$ denotes p-value $<.01$, ** denotes $\mathrm{p}$-value $<.05$, and $*$ denotes p-value $<.1$. 


\section{Table A.21: Robustness Tests of Private Equity Ownership and Article Content}

\begin{tabular}{|c|c|c|c|c|c|}
\hline \multirow{3}{*}{ Dependent Variable: } & \multicolumn{3}{|c|}{ Panel A: Fractional Share GLM } & \multirow[b]{2}{*}{$\begin{array}{c}\text { National } \\
\text { Politics }\end{array}$} & \multirow[b]{2}{*}{ AP Wire } \\
\hline & $\begin{array}{c}\text { Local } \\
\text { Government }\end{array}$ & Obituaries & China/Russia & & \\
\hline & $(1)$ & $(2)$ & (3) & (4) & (5) \\
\hline Post deal X PE & $\begin{array}{c}-0.182^{* * *} \\
(0.068)\end{array}$ & $\begin{array}{l}-0.110^{*} \\
(0.064)\end{array}$ & $\begin{array}{l}0.087^{*} \\
(0.052)\end{array}$ & $\begin{array}{c}0.106^{*} \\
(0.058)\end{array}$ & $\begin{array}{l}-0.177 \\
(0.140)\end{array}$ \\
\hline Observations & 10952 & 10952 & 10952 & 10952 & 10952 \\
\hline Year FE & Yes & Yes & Yes & Yes & Yes \\
\hline Newspaper FE & Yes & Yes & Yes & Yes & Yes \\
\hline Outcome Mean & 0.332 & 0.139 & 0.017 & 0.157 & 0.050 \\
\hline \multirow{3}{*}{ Dependent Variable: } & \multicolumn{3}{|c|}{ Panel B: Sample with Employment Data } & & \\
\hline & $\begin{array}{c}\text { Local } \\
\text { Government }\end{array}$ & Obituaries & China/Russia & $\begin{array}{l}\text { National } \\
\text { Politics }\end{array}$ & AP Wire \\
\hline & (1) & (2) & (3) & (4) & (5) \\
\hline Post deal X PE & $\begin{array}{c}-0.040^{* *} \\
(0.016)\end{array}$ & $\begin{array}{l}-0.013 \\
(0.008)\end{array}$ & $\begin{array}{c}0.001 \\
(0.001)\end{array}$ & $\begin{array}{c}0.009 \\
(0.007)\end{array}$ & $\begin{array}{l}-0.009 \\
(0.007)\end{array}$ \\
\hline Observations & 7865 & 7865 & 7865 & 7865 & 7865 \\
\hline Year FE & Yes & Yes & Yes & Yes & Yes \\
\hline Newspaper FE & Yes & Yes & Yes & Yes & Yes \\
\hline Outcome Mean & 0.334 & 0.134 & 0.018 & 0.159 & 0.055 \\
\hline
\end{tabular}

Note: This table shows the impact of private equity buyouts on the share of a newspaper's total articles that fall into a particular topic area. The model in Panel A is fractional logit GLM. Panel B restricts the sample to that for which we observe employment outcomes. Content topic areas are defined above. $* * *$ denotes $\mathrm{p}$-value $<.01$, ** denotes $\mathrm{p}$-value $<.05$, and $*$ denotes $\mathrm{p}$-value $<.1$. 


\section{Table A.22: Private Equity Ownership and Levels of Employees \& Operations}

\begin{tabular}{lcccc}
\hline \multicolumn{5}{c}{ Panel A: Employment } \\
Dependent Variable: & Reporters & Editors & $\begin{array}{c}\text { Interns \& } \\
\text { Freelancers }\end{array}$ & Employees \\
& & & & \\
& & & $(3)$ & $(4)$ \\
\hline Post deal X PE & $-0.778^{* * *}$ & $-0.901^{* *}$ & -0.023 & $-4.917^{* * *}$ \\
& $(0.279)$ & $(0.374)$ & $(0.132)$ & $(1.632)$ \\
\hline Observations & 16466 & 16466 & 16466 & 16466 \\
$R^{2}$ & 0.930 & 0.923 & 0.829 & 0.960 \\
Year FE & Yes & Yes & Yes & Yes \\
Newspaper FE & Yes & Yes & Yes & Yes \\
Outcome Mean & 1.268 & 1.794 & 0.585 & 2.637 \\
\hline
\end{tabular}

Panel B: Circulation \& Advertising

\begin{tabular}{|c|c|c|c|c|c|}
\hline \multirow[t]{2}{*}{ Dependent Variable: } & \multicolumn{3}{|c|}{ Circulation } & \multicolumn{2}{|c|}{ Advertising Rate } \\
\hline & $\begin{array}{c}\text { No Stale } \\
\text { (1) }\end{array}$ & $\begin{array}{l}\text { All } \\
(2)\end{array}$ & $\begin{array}{l}\text { Digital } \\
\text { (3) }\end{array}$ & $\begin{array}{c}\text { No Stale } \\
\text { (4) }\end{array}$ & $\begin{array}{l}\text { All } \\
(5)\end{array}$ \\
\hline Post deal X PE & $\begin{array}{c}-3787.656^{* * *} \\
(958.889)\end{array}$ & $\begin{array}{c}-4013.069^{* * *} \\
(830.142)\end{array}$ & $\begin{array}{c}4966.516 \\
(11871.322)\end{array}$ & $\begin{array}{l}-0.326 \\
(3.240)\end{array}$ & $\begin{array}{l}-1.716 \\
(2.494)\end{array}$ \\
\hline Observations & 14931 & 22764 & 3369 & 10470 & 22152 \\
\hline$R^{2}$ & 0.933 & 0.930 & 0.495 & 0.788 & 0.848 \\
\hline Year FE & Yes & Yes & Yes & Yes & Yes \\
\hline Newspaper FE & Yes & Yes & Yes & Yes & Yes \\
\hline Outcome Mean & 9.781 & 9.427 & 5.261 & 3.200 & 3.183 \\
\hline
\end{tabular}

Note: This table shows the impact of private equity buyouts on the level number of employees in key occupations and operational outcomes, rather than logs as in our main specification. Standard errors are clustered by newspaper. $* * *$ denotes p-value $<.01, * *$ denotes $\mathrm{p}$-value $<.05$, and $*$ denotes p-value $<.1$. 
Table A.23: Robustness Tests of Heterogeneity

\begin{tabular}{|c|c|c|c|c|}
\hline \multicolumn{5}{|c|}{ Panel A: Employment Effects by Distribution } \\
\hline \multirow{3}{*}{ Sample: } & \multicolumn{2}{|c|}{ Circulation } & \multicolumn{2}{|c|}{ Local Govt Share } \\
\hline & $<$ Median & $\geq$ Median & $<$ Median & $\geq$ Median \\
\hline & (1) & (2) & (3) & (4) \\
\hline Post deal X PE & $\begin{array}{l}-0.087 \\
(0.063)\end{array}$ & $\begin{array}{l}-0.048 \\
(0.046)\end{array}$ & $\begin{array}{c}-0.144^{* * *} \\
(0.055)\end{array}$ & $\begin{array}{l}-0.068 \\
(0.055)\end{array}$ \\
\hline Observations & 5731 & 6850 & 3687 & 3555 \\
\hline$R^{2}$ & 0.276 & 0.153 & 0.179 & 0.228 \\
\hline Year FE & Yes & Yes & Yes & Yes \\
\hline Newspaper FE & Yes & Yes & Yes & Yes \\
\hline Outcome Mean & 1.527 & 3.360 & 3.160 & 2.175 \\
\hline \multicolumn{5}{|c|}{ Panel B: Local News Content Changes Effects by Distribution } \\
\hline & \multicolumn{2}{|c|}{ Circulation } & \multicolumn{2}{|c|}{ Local Govt Share } \\
\hline \multirow[t]{2}{*}{ Sample: } & $<$ Median & $\geq$ Median & $<$ Median & $\geq$ Median \\
\hline & (1) & (2) & (3) & (4) \\
\hline Post deal X PE & $\begin{array}{c}-0.316^{* * *} \\
(0.082)\end{array}$ & $\begin{array}{c}-0.194^{* * *} \\
(0.070)\end{array}$ & $\begin{array}{c}-0.158^{* *} \\
(0.068)\end{array}$ & $\begin{array}{c}-0.348^{* * *} \\
(0.087)\end{array}$ \\
\hline Observations & 5456 & 5485 & 5473 & 5479 \\
\hline$R^{2}$ & 0.693 & 0.644 & 0.731 & 0.735 \\
\hline Year FE & Yes & Yes & Yes & Yes \\
\hline Newspaper FE & Yes & Yes & Yes & Yes \\
\hline Outcome Mean & 7.305 & 8.481 & 8.269 & 7.520 \\
\hline
\end{tabular}

Note: This table shows the impact of private equity ownership and employment and news outcomes across the distribution. In Panel A, we consider employment outcomes and in Panel B we examine changes in local news content. We estimate the average circulation for newspapers over their life, and divide the sample into below and above median circulation. Similarly, we measure the ratio of news items which are local compared with national news, and compare newspapers which are below and above median in this local news ratio across their life. $* * *$ denotes $\mathrm{p}$-value $<.01$, ** denotes $\mathrm{p}$-value $<.05$, and $*$ denotes p-value $<.1$. 